\title{
What Comes After the Boom? Baby Boomers in Santa Maria, California A Market Study for People's Self Help Housing
}

\author{
A Project \\ presented to \\ the Faculty of California Polytechnic State University, \\ San Luis Obispo
}

\author{
In Partial Fulfillment \\ of the Requirements for the Degree \\ Master of City of Regional Planning
}

by

Elizabeth Brighton

June 2013 
(C) 2013

\section{Elizabeth Brighton}

\section{ALL RIGHTS RESERVED}

Page ii 
COMMITTEE MEMBERSHIP

TITLE:

AUTHOR:

DATE SUBMITTED:

COMMITTEE CHAIR:

COMMITTEE MEMBER:

COMMITTEE MEMBER:

COMMITTEE MEMBER:
WHAT COMES AFTER THE BOOM?

Baby Boomers in Santa Maria, California

A Market Study for People's Self-Help Housing

Elizabeth Brighton

June 2013

Dr. Kelly D. Main, Professor

City and Regional Planning Department

Lisa Wise, AICP

City and Regional Planning Lecturer

President- Lisa Wise Consulting, Inc.

Tyler Corey, Housing Programs Manager

City of San Luis Obispo

Morgen Benevedo, Project Manager

People's Self Help Housing 


\author{
ABSTRACT \\ What Comes After the Boom? \\ Baby Boomers in Santa Maria, California \\ A Market Study for People's Self Help Housing \\ Elizabeth Brighton
}

This Master's Project is separated into two parts: the introduction and background informing an affordable senior housing market study, and a market study prepared for People's Self Help Housing (PSHH). The introduction begins by providing current and future trends for seniors at the national and state levels. This includes discussion of the "Baby Boomer" age cohort and their rapid growth and potential impact to the housing market. The introduction then describes challenges facing developers of affordable senior housing. These challenges include the type, location, and funding sources for future senior housing projects. All federal funding sources for affordable senior housing projects are then briefly presented and their applicability to the proposed project is explained. The introduction sets the stage for a market study created to determine the feasibility of an affordable senior housing project in the Santa Maria/Orcutt market area.

Keywords: affordable senior housing, market study 


\section{ACKNOWLEDGMENTS}

Without the following list of characters, this project would not have been possible.

\section{Kelly Main}

Thank you for always making me feel good about myself and reassuring me that I was doing a "good" job. You helped me learn a valuable lesson that I can complete a "good" project without over-doing it and making myself sick from overworking. Thank you for your patience with me and your constant encouragement.

\section{My Committee}

Thank you for bearing with me as I fell off the radar. I hope that you have enjoyed reading my project, and I hope that it is helpful to $\mathrm{PSHH}$.

\section{Fellow Classmates}

You heard me complain on more than one occasion about the long list of things on my mind the past two quarters (scratch that- two years!), and yet, you are still my friend! Thank you for all the laughs, your belief in me and my abilities, and the excitement that you bring to class and life outside of class.

My Family

I first want to thank my heavenly family; thank you God for sustaining me these past two years! I'll never quite understand why you love me, but I am joyful and grateful that you do. Secondly, thank you to my parents and siblings for your unwavering support and prayers. And last, but most definitely not least, thank you to my fiancé for your love and support; you make life fun! 


\section{TABLE OF CONTENTS}

LIST OF TABLES

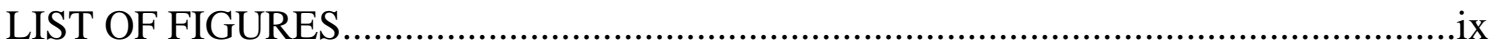

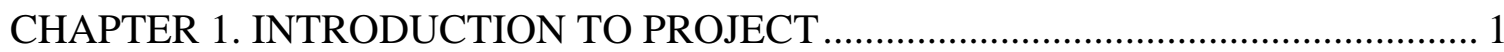

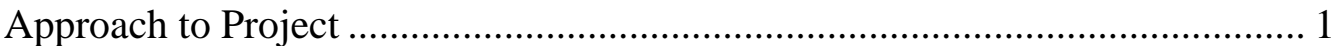

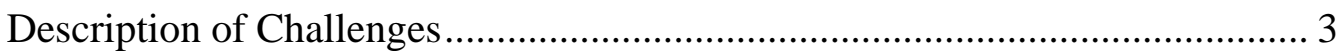

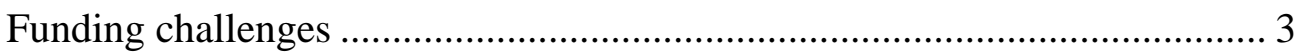

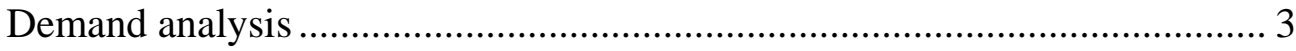

Site zoning and location challenges ........................................................... 3

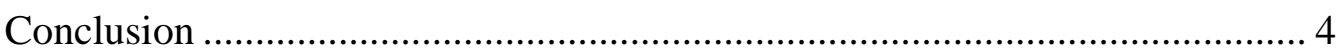

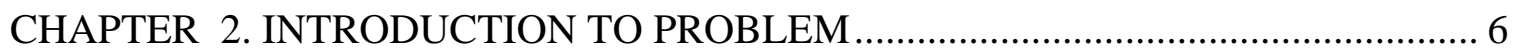

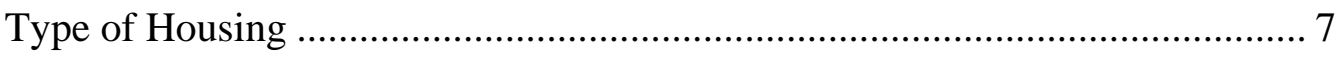

Location of Housing ............................................................................. 8

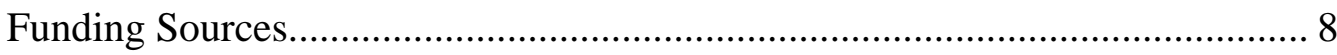

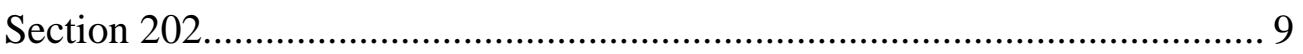

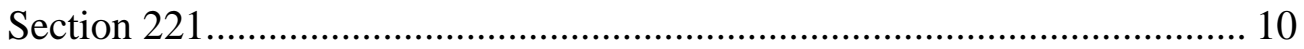

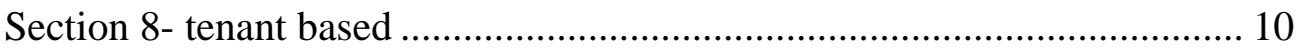

Page vi 
Section 8- project based.

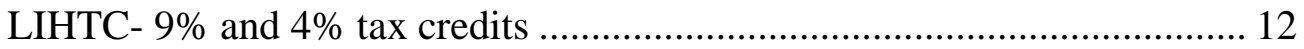

HOME investment partnership program................................................ 13

Community Development Block Grants (CDBG) ................................... 14

CHAPTER 3. METHODOLOGY FOR THE PROJECT ........................................ 15

Description of Project ........................................................................... 15

Identification of Market Area ….............................................................. 15

Survey of Existing Senior Housing in Market Area ..................................... 16

Survey of Site and Surrounding Areas.......................................................... 16

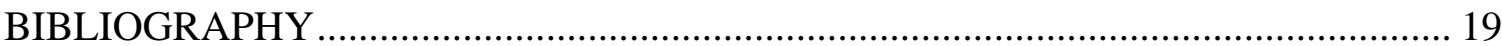

\section{APPENDICES}

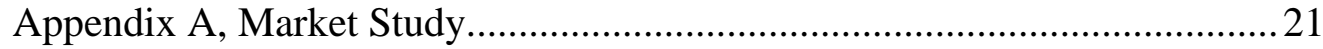

Appendix B, Pre-application and preliminary site plans..............................67

Appendix C, ESRI Demographics Report.....................................................69 


\section{LIST OF TABLES}

Table 1. Case-Study Matrix..................................................................................... 17 


\section{LIST OF FIGURES}

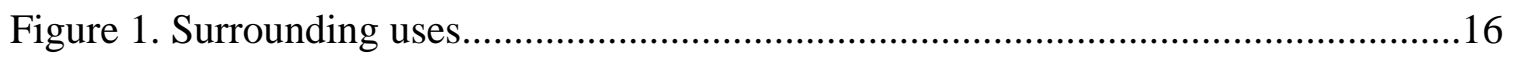

Page ix 


\section{CHAPTER 1. INTRODUCTION TO PROJECT}

The People's Self Help Housing Corporation (PSHH) was formed in 1970 in San Luis Obispo to address the founders' concern about the lack of affordable housing available to low-income and special needs households. Since its formation, PSHH has provided homes for more than 5,000 low-income adults and children. PSHH is in the process of purchasing a property in the City of Santa Maria with which they intend to develop affordable senior housing units. PSHH is interested in learning more about the type of housing desired by the Baby Boomer population. As the first cohort of Boomers turned 65 in 2011, PSHH wants their development to meet current and future senior housing needs and wants. This project will provide PSHH with a market study for the Santa Maria area that analyzes demographic trends, market feasibility for affordable senior housing, project site feasibility, and the ability of the project to meet local regulations.

\section{Approach to Project}

The first step in approaching this project was to understand current senior housing trends at the national and state levels. At the national level, the following reports were read and analyzed: Reports from the U.S. Senate's Special Committee on Aging, the State of the Nation's Housing 2012 Report produced by the Joint Center for Housing Studies of Harvard University, and AARP and NAHB surveys. At the state level, California's Department of Housing and Community Development's State of Housing 2012 Report informed current and future senior trends. These sources offer data regarding demographic trends and future housing needs and relay the needs and wants of 
Baby Boomers and how they will influence the housing market in the next decade. The findings in these sources set the scene in which local housing decisions are made.

After researching national and state trends, the next course of action for this project was to understand the state of federal funding for senior affordable housing. The U.S. Department of Housing and Urban Development (HUD) summarizes all federal funding opportunities on their website. Research performed in identifying the aforementioned national housing trends also identified national funding sources and their status. Discussions with countywide and local grantees of these funds lent to the discussion of availability of funding and the affect that cuts in federal funding have had on funds supporting affordable housing.

The 2010 Census and ESRI's Business Analyst Online (BAO) were utilized to collect project-specific demographic data included in the market study. As PSHH intends to pursue Low-Income Housing Tax Credit (LIHTC) financing, market study guidelines provided by the LIHTC committee informed the content of this market study. Existing income-restricted and market-rate senior housing developments were first identified then followed by a site visit and an interview with the Property Manager or Community Relations Director of the development. The list of interview questions were loosely derived from the categories listed in the rent matrix comparison provided by the LIHTC committee (SEE APPENDIX). Site specific challenges (listed in the paragraph below) were identified in speaking with PSHH staff and City of Santa Maria planning staff. 


\section{Description of Challenges}

\section{Funding challenges}

Recent federal budget cuts have resulted in drastic cuts for many federally funded programs including the funding of affordable housing. Evidence of these cuts exists in the discontinuance of funding for new Section 202 awards and project-based Section 8 funds, decreased funds released for HOME and CDBG grants, and fewer tenant-based Section 8 vouchers (these funding sources are defined on pgs. 7-11). PSHH applied for 2012 HOME funds but did not receive any as the project was still in its preliminary stages without any planning approvals. Projects are more competitive and more likely to receive funding when closer to breaking ground.

\section{Demand analysis}

The demand analysis presented in the market study (see Appendix) does not result in a clear demand. The little or no vacancies in existing income-restricted senior housing in the market area and presence of wait lists indicate the presence of a need for more affordable senior housing options in the market area.

\section{Site zoning and location challenges}

While the proposed site is a couple of blocks from several senior-desired uses (senior center, parks, urgent care, pharmacy), the site is a half-mile from the closest transit stop. While is a half-mile walk is defined as "walkable" in smart growth planning, a half-mile is out of walking range for many seniors. There is a dial-a-ride for seniors called SMOOTH, which takes seniors around town for a $\$ 6$ round trip fee. The proposed site is currently zoned R-1 (Single-Family Residential) and as such does not support the 
proposed density. The proposed project would require re-zoning the parcel to R-3 (HighDensity Residential) or possibly R-2 (Medium-Density Residential) if the proposed unit count were to be lowered. Initial conversations with City staff indicated concern with rezoning a parcel to a multi-family designation when bordered by single-family residential due to density and traffic impacts, especially if PSHH decided to not pursue the project after a re-zone, thus opening the door to a market-rate multi-family housing development which may have greater impacts on surrounding uses than senior housing.

\section{Conclusion}

The proposed location at $624 \mathrm{E}$. Camino Colegio is one block from the Elwin Mussell Senior Center, a community garden, and Alice Trefts Park. The site is two blocks from the Marian Medical Urgent Care and other doctor's offices and pharmacies, and a half-mile from Trader Joe's and Costco grocery stores, the Santa Maria transit (SMAT) center, Hancock College, and Simas Park. The site is less than one-mile from Foods Co., Von's, and the public library. With all of these surrounding senior-desired uses within one mile, the proposed location is ideal for a senior housing development with one exception. While these uses are within a "walkable distance" according to popular New Urbanism standards, for many seniors, their health does not allow for them to take even a half mile walk. While the two SMAT stops a half mile from the proposed site could thus be out of reach for seniors, there are senior service organizations in Santa Maria that offer discounted or free rides to seniors. The survey of existing affordable senior housing revealed two projects with wait lists with at least 12 people on them and little to no vacancies for any of the units. Additionally, in the market area in 2010, more 
than fifty-percent of seniors over the age of sixty-five were spending more than thirtypercent of their income on rent. It is likely that there may be some conversion from market-rate senior renters to income-restricted housing as well as senior homeowner conversion to income-restricted senior housing. With these three supporting factors, location, existing wait-lists, and conversion rates, demand appears to support the proposed additional supply of the proposed 39 units. 


\section{CHAPTER 2. INTRODUCTION TO PROBLEM}

The "Baby Boomers," "pig moving through the python," "the bulge," and are all monikers for the large age cohort of persons born between the years 1946 and 1964. In the State of California, the number of seniors 65 years of age and older is projected to double from 4.3 million in 2010 to 8.4 million in 2030 (HCD, 2012, p. 5). The cause of this shift in population includes people living increasingly longer lives and the Baby Boomer generation reaching senior-hood; the oldest group of Boomers turned 65 in 2011. Baby Boomers have drastically affected the housing market in each stage of their lives, and it is likely that senior-hood will be no different. The approximately $100 \%$ increase in California seniors is projected to cause an increased demand for all types of senior housing, including affordable housing. For the past thirty years, non-profit People's Self Help Housing (PSHH) has been dedicated to meeting the housing needs of low-income families, seniors, and disabled persons. PSHH recently acquired a parcel in Santa Maria, California and wants to explore the possibility of creating senior housing at the site. This report will serve as guidance for People's Self Help as they approach developing the site and other future affordable senior housing projects.

As the fastest growing city in Santa Barbara County, the City of Santa Maria recognizes in the City's Housing Element the need for more affordable senior housing. The Housing Element states there are 445 existing income-restricted senior housing rental units within City limits. The Housing Element states that an estimated 4,694 owner-occupied units and 1,267 renter-occupied units are needed to serve the current senior population. In order to meet this current need and anticipate future need, it is 
necessary to understand current and potential issues with the affordable senior housing stock. They are: the type of units in the current housing stock may not be compatible with the type of housing desired by Boomers; the type of location may not be the most appropriate for senior housing, and diminishing federal funding for affordable units.

\section{Type of Housing}

A 2009 study completed by real estate advisory firm Robert Charles Lesser and Company found that 75 percent of the retiring Baby Boomer cohort want to live in mixed-age and mixed-use developments in more urban areas with easy access to services (Logan, Kannan, \& Siejka, 2009). Traditional funding sources do not allow senior housing to be mixed age. All federally assisted senior units are required to be restricted to persons 62 years of age and older. According to a 2010 survey of the oldest Baby Boomers (age 64 when surveyed) and the youngest Baby Boomers (age 50 when surveyed) by senior community developer Del Webb, $20 \%$ of the older Boomers preferred age-restricted housing while only $9 \%$ of the younger Boomers preferred agerestricted housing (Del Webb, 2010).HUD's HOPE VI program initiated a new type of affordable housing in which the typical public housing enclave model was abandoned in favor of mixed-income developments. Perhaps there will be demand for the same type of transition in senior housing, but the current funding structure and income-restrictions do not allow for such flexibility. A survey conducted by the National Association of Home Builders in 2000 identified Baby Boomers' most desired amenity when searching for a home to be walking or jogging trails in close proximity. The survey also found that the age cohort values the outdoors and open space including lakes and pools, as well as 
clubhouses, exercise rooms, business centers, and public transportation (Salkin, 2003, p. 194).

\section{Location of Housing}

The aforementioned surveys found that Baby Boomers desire more centralized housing locations than the isolated senior housing developments of the past. As land in urban areas in California is increasingly more developed than suburban areas, the amount of land available for new construction in such locations will become scarcer. Affordable housing developers will need to look to rehabilitation of existing apartment buildings or the re-purposing of buildings such as hotels or closed schools to accommodate senior housing. The recent re-investment in transit-oriented developments by market-rate developers has raised the price tag of land in transit-rich neighborhoods. As this proves cost-prohibitive for affordable housing developers, affordable housing can easily be pushed further from needed access to transportation. Where cities have adopted inclusionary housing requirements, the push away from transit-rich areas may be lessened; the potential market demand for senior housing in such transit-rich locations may also lessen the impact. In a 2003 AARP study, Baby Boomers listed the following as necessary components of their neighborhood: feeling safe, living near a hospital or doctor, places of worship, shopping centers, grocery stores, and drug stores (Salkin, 2003, p. 183).

\section{Funding Sources}

With the continuing decrease in federal and state funding for affordable housing, it is important to note not only the current status of funding sources for affordable senior 
housing projects but also the pressures on that funding from affordability contracts set to expire in the next decade. The future of affordable housing is threatened by the number of units at risk of conversion to market rate housing. A large percentage of project-based Section 8 housing developments were created in the 1970's with a forty-year contract of affordability (see p. 10, Section 8 defined). It is estimated that 68,000 of the federally subsidized affordable apartments in California are at-risk of conversion to market rate in the next five years, with an additional 74,000 becoming at risk in the next 15 years (HCD, 2012, p. 16). Federal, state, and local funding will need to be allocated to keep these affordable units affordable while also allocating funding for new construction for the increasing senior population. The diminishing amount of funding allocated for existing and future affordable senior housing developments presents a stumbling block for affordable housing developers. The following paragraphs briefly describe each of the possible funding sources of senior housing and their current status and applicability to the proposed project.

\section{Section 202}

The Section 202 program is the only federal funding source solely dedicated to housing very low-income elderly. Section 202 units are restricted to persons 62 and older with an income at or less than $50 \%$ of the average median income (AMI) for the County in which the project is located. This HUD program offers interest-free capital advances for projects by non-profit applicants. These advances do not require repayment as long as the housing development remains affordable to very-low income seniors for forty years. Section 202 funding also provides rent subsidies for projects intended to bridge 
the gap between the HUD-approved operating cost for the project and the very lowincome tenants' contribution towards rent (30\% of their income). PSHH has created two projects in Santa Maria by leveraging Section 202 funding. Section 202 funding was established in 1959, and many of the 202 units existing today were built in the two decades following its establishment. As the developments were formed with 30 and 40 year affordability contracts, thousands of 202 units are currently at risk of conversion to market rate housing. Currently, the federal budget has allocated funds for renewing existing 202 contracts on a one-year basis until the first quarter of 2014 . The 2013 budget does not include funding for any new Section 202 contracts (capital advances or rent subsidies). This presents a challenge for PSHH as no other federal funding source is earmarked solely for senior housing and this loss of funding creates more competition for other potential funding sources.

\section{Section 221}

Section 221(d) (3) provides mortgage insurance for mortgage loans that facilitate the development of multi-family rental housing for moderate-income families, the elderly, and disabled persons. The program allows for the financing of $100 \%$ of a longterm 40-year mortgage insurance policy, but the insured mortgage must be used to finance housing with at least five units in each building. This caveat does not meet the proposed development plan.

\section{Section 8- tenant based}

There are two forms of Section 8 funding: tenant-based and project-based. The tenant-based or Housing Choice Voucher can be used at any private rental unit where the 
landlord accepts Section 8 vouchers (not required by law to accept vouchers). The local public housing authority is the agency that releases the vouchers to landlords. The housing authority first determines a payment standard (generally the amount needed to rent a moderately-priced rental unit in the local housing market) and then calculates the voucher by either the payment standard rent amount minus $30 \%$ of the family's monthly adjusted income or the actual unit rent minus $30 \%$ of monthly adjusted income, whichever is less. These vouchers allow very-low income families, disabled persons, and the elderly to rent market-rate units in any place in the U.S. with a public housing authority. Federal budget cuts have resulted in a drop in the number of vouchers issued; early estimates state more than 100,000 families in the U.S. could lose housing voucher assistance this year(CBPP, 2013). Vouchers could give Baby Boomers the more desired urban location and flexibility, but landlords are not required to accept Section 8 vouchers and can refuse them outright. Many apartment complexes that accept Section 8 vouchers do not provide the type of assistance needed by seniors.

\section{Section 8- project based}

The second form of Section 8 assistance is project-based, meaning that rental assistance stays with the project rather than with the person. Project-based assistance makes up the difference between the tenant's contribution (30\% of income) and the rent standard for the market area decided upon by HUD. The 2013 federal budget does not allocate funds for any new Section 8 project-based contracts, but has accounted for the renewing of expiring contracts for another year. Project-based Section 8 is yet another 
former funding source for affordable housing that did not receive funding for new projects in the current fiscal year.

\section{LIHTC- $9 \%$ and $4 \%$ tax credits}

The Low-Income Housing Tax Credit (LIHTC) program has been a significant source of new multifamily housing since it was added to the Internal Revenue Code in 1987. Since 1987, more than 2 million units have been created with tax credits. The Internal Revenue Service (IRS) allocates housing tax credits to state housing finance agencies for them to award tax credits to developers of qualified affordable housing projects. The $4 \%$ tax credit is given in a non-competitive "as of right" credit to qualified low-income housing projects. The $9 \%$ tax credit is a competitive process in which credits are awarded to the projects serving the lowest income families and with the longest affordability time period. If awarded the credits, the developer can choose to claim the credits (the credits will be applied annually for ten years) or the developer can choose to sell those tax credits to an investor or syndication. The investors or syndicates will pay the developer an amount upfront, for example, $\$ 100,000$, to purchase tax credits that the investor will then collect annually for a total of say $\$ 150,000$. The affordable housing developer thus receives needed equity at the start of the project through the selling of credits. The equity from LIHTC typically covers about half of the development costs for affordable housing projects. Most developers combine the LIHTC with the source of funding discussed below, the HOME investment partnership program. PSHH hopes to receive low-income housing tax credits and has proposed $100 \%$ of the units to be 
occupied by very low-income seniors and intends to manage it as affordable senior housing in perpetuity.

\section{HOME investment partnership program}

The HOME program is a block grant given to states, eligible large jurisdictions, and consortiums of smaller jurisdictions. The federal government allocates grants to each of these entities according to housing need and supply, and the presence of poverty or fiscal distress. In order for an entity to be eligible for the grant, the entity must have a five-year consolidated plan and an annual action plan indicating how the grant will be used. The grant provides flexible funding for a range of activities that better low-income housing options in communities; from direct subsidies to construction of new low-income projects. Santa Maria belongs to a consortium made up of unincorporated Santa Barbara County and the cities of Buellton, Carpinteria, Lompoc, Solvang, and Goleta. Both the County's 2010-2015 Consolidated Plan and Santa Maria’s 2013-2014 Annual Action Plan would need to be amended to include the proposed project if it were eligible for a grant. The proposed project directly meets objectives put in place by the HOME Consortium which states:

"There is a serious need for new construction / acquisition / rehabilitation of rental housing for lower income households, including large households, small households and special needs households (including homeless, disabled, and elderly persons)." (Consolidated Plan, p. VIII-9). 
The proposed project also meets the priority listed as number one in the City of Santa Maria’s Annual Action Plan which reads:

"Address the housing, health care and service needs of the elderly, frail elderly, persons with mental, physical, and developmental disabilities, and persons with AIDS.”(Santa Maria AAP, p. 21)

\section{Community Development Block Grants (CDBG)}

This block grant program provides annual grants on a formula basis to cities that meet HUD's population eligibility requirements. Seventy-percent of the block grant funds must be used for activities that benefit low- and moderate-income persons. These activities include land acquisition, relocation, demolition, and rehabilitation of existing residential developments, construction of public improvements such as streets or sidewalks, and others. CDBG monies cannot be used to construct new housing units. In addition to the above HOME funds, PSHH could also apply for CDBG funding to aid in the cost of land acquisition or required public improvements. 


\section{CHAPTER 3. METHODOLOGY FOR THE PROJECT}

As PSHH intends to pursue low income housing tax credits for the proposed project, the California Tax Credit Allocation Committee's market study guidelines were used as an outline for the enclosed market study. The following paragraphs detail the needed sections in the market study and how each was approached.

\section{Description of Project}

This proved to be a difficult step as PSHH is not quite to this level of specificity for the subject site. Currently, PSHH has requested a Lot Line Adjustment through the City of Santa Maria to create two parcels where one currently exists. The parcel at 624

E. Colegio Camino is currently an approximately five-acre lot comprised of Bethel Lutheran Church, a parking lot, and approximately two-and-a-half acres of vacant land to the rear of the church. The Lot Line Adjustment would create a second parcel comprised of the vacant two-and-a-half acres. PSHH has submitted a pre-application (see Appendix) to the City to determine the feasibility of a senior housing development in a parcel zoned R-1. For the purposes of the market study, an approximate number of units and unit square footages was created that reflects conceptual proposals from PSHH, but may change as the project progresses.

\section{Identification of Market Area}

The first step in conducting a market study is defining the market area. In speaking with representatives from PSHH, it became apparent that Orcutt (a census designated place outside of city limits) would somehow need to be included in the study as Orcutt has a greater percentage of seniors than the city proper and is seen as the "nice 
southern portion of Santa Maria.” Orcutt also has several senior housing developments, both market rate and affordable, which were important to include as they affect the existing demand for senior housing in the Santa Maria area. ESRI's Business Analyst Online (BAO) software was utilized to examine the demographics of the market area as the Credit Allocation Committee requires demographic projections to be from a reliable source.

\section{Survey of Existing Senior Housing in Market Area}

Per the Tax Credit Committee guidelines, a survey of existing low-income and market-rate housing is required. The survey was conducted by first reading the City of Santa Maria's Housing Element to identify the senior projects recognized by the City. An online search then produced the needed market-rate housing developments included in the study. A walk-through of each housing development was conducted as well as an interview with each property manager to fill out the required boxes in the rent comparability matrix provided by the Committee (see Appendix).

\section{Survey of Site and Surrounding Areas}

First, mapping of

surrounding assets was conducted

to determine whether or not the site was appropriately located for senior housing (See Appendix A, Market Study). Google Streetview was

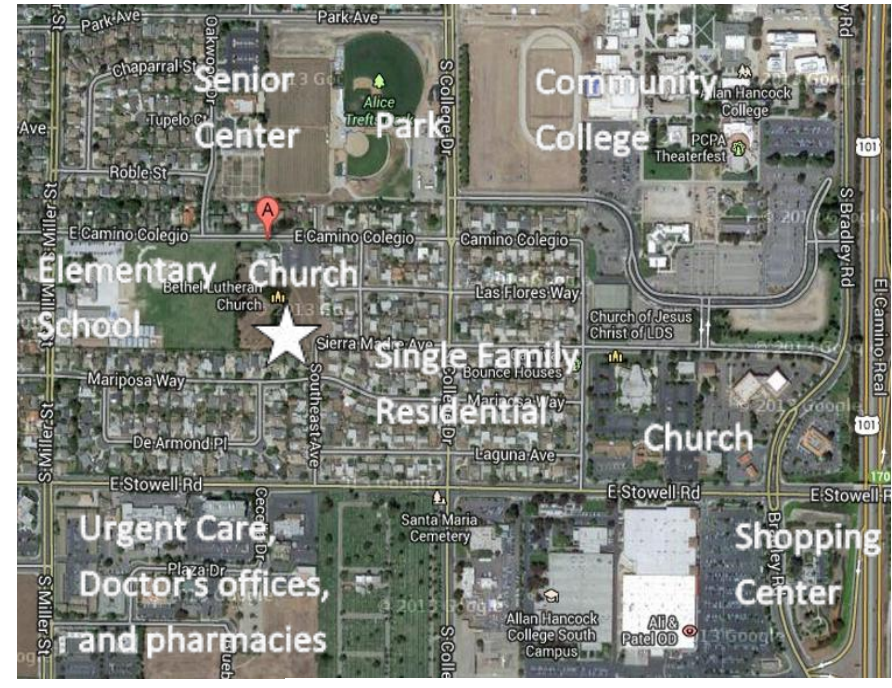

Page 16
Figure 1. Surrounding Uses 
first utilized to map existing assets, followed by site visits on foot. The proposed project site and surrounding neighborhood was then walked through and recorded with photographs.

The table below lists seven categories upon which market studies were evaluated to include as examples in the creation of the enclosed market study. Market studies were difficult to procure as consultants are careful to not release such reports into the public sphere without compensation. Two of the three reports listed were prepared for PSHH for affordable housing projects in the Central Coast. While these projects were not senior housing projects, they provided guidance in forming a report using the Tax Credit Committee guidelines and provided examples of what PSHH expects in a market study. The third study, a senior housing study in Oregon, provided an example of study completed only for senior housing. It provided valuable insight into the types of seniorspecific data that require inclusion.

Table 1. Case-Study Matrix

\begin{tabular}{|c|c|c|c|c|c|c|c|}
\hline \multicolumn{8}{|c|}{ MARKET STUDY CASE-STUDY MATRIX } \\
\hline Report Title & $\begin{array}{l}\text { Date of } \\
\text { Report }\end{array}$ & California & LIHTC & $\begin{array}{l}\text { Affordable } \\
\text { Housing }\end{array}$ & $\begin{array}{l}\text { Senior } \\
\text { Housing }\end{array}$ & Local & $\begin{array}{l}\text { Written } \\
\text { for } \\
\text { PSHH }\end{array}$ \\
\hline $\begin{array}{l}\text { Courtland } \\
\text { Market Study- } \\
\text { Arroyo Grande }\end{array}$ & Mar 12 & $X$ & $X$ & $X$ & & $X$ & $\mathrm{X}$ \\
\hline $\begin{array}{l}\text { Senior } \\
\text { Housing } \\
\text { Market } \\
\text { Analysis- } \\
\text { Cornelius, OR }\end{array}$ & Sept 12 & & $\mathrm{X}$ & $\mathrm{X}$ & $X$ & & \\
\hline $\begin{array}{l}\text { Santa Maria } \\
\text { Los Adobes } \\
\text { De Maria III } \\
\text { Market Study }\end{array}$ & Aug 12 & $X$ & $X$ & X & & $X$ & $X$ \\
\hline
\end{tabular}


The following market study (Appendix A) was conducted to provide a snapshot of the current housing market in the Santa Maria-Orcutt Market Area and the project housing demand the approximate year that the proposed project will enter the market (2017). If PSHH chooses to pursue the senior housing project substantially as they have proposed (See Appendix B, Conceptual site plan), the project will require a zone change from R-1 to R-3. The following market study will provide PSHH with demographic data and surrounding services for the proposed project that will guide them as they continue to explore the feasibility of senior housing at the proposed site. 


\section{BIBLIOGRAPHY}

2010 Del webb baby boomer survey. (2010). Retrieved from http://dwboomersurvey.com/

City of Santa Maria. (2013). 2013-2014 Annual action plan. Retrieved from http://www.cityofsantamaria.org/40409-FinalActionPlanFY2013-14.pdf

City of Santa Maria. (2010). General plan housing element. Retrieved from http://www.cityofsantamaria.org/40559-CompleteHousingElementDocument.pdf

County of Santa Barbara. (2010). 2010-2015 Consolidated plan. Retrieved from http://www.countyofsb.org/uploadedFiles/housing/HDGA/FINAL_CONPLAN_ W_COVER.pdf

Department of Housing and Community Development. (2012). The state of housing in california 2012. Retrieved from http://www.housingsandiego.org/wp-content/uploads/2013/02/The-State-ofHousing-in-California-2012.pdf

Logan, G., Kannan S, \& Siejka S. (2009). The market for smart growth. Robert Charles Lesser and Company, LLC. Retrieved from http://www.epa.gov/smartgrowth/pdf/logan.pdf

Salkin, P. E. (2003). Where will the baby boomers go? Planning and zoning for an aging population. Real Estate Law Journal, 32(181), Retrieved from http://www.governmentlaw.org/files/planning_zoning_for_aging.pdf

The Joint Center for Housing Studies of Harvard University. (2012). The state of the nation's housing 2012. Retrieved from http://www.jchs.harvard.edu/sites/jchs.harvard.edu/files/son2012.pdf

U.S. Department of Housing and Urban Development. (2013). Retrieved from http://portal.hud.gov/hudportal/HUD?src=/program_offices/housing/mfh/progdes $\underline{\mathrm{c}}$ 


\section{APPENDICES}
A. Market Study
B. Pre-application and preliminary site plans
C. ESRI Demographics Report

Page 20 


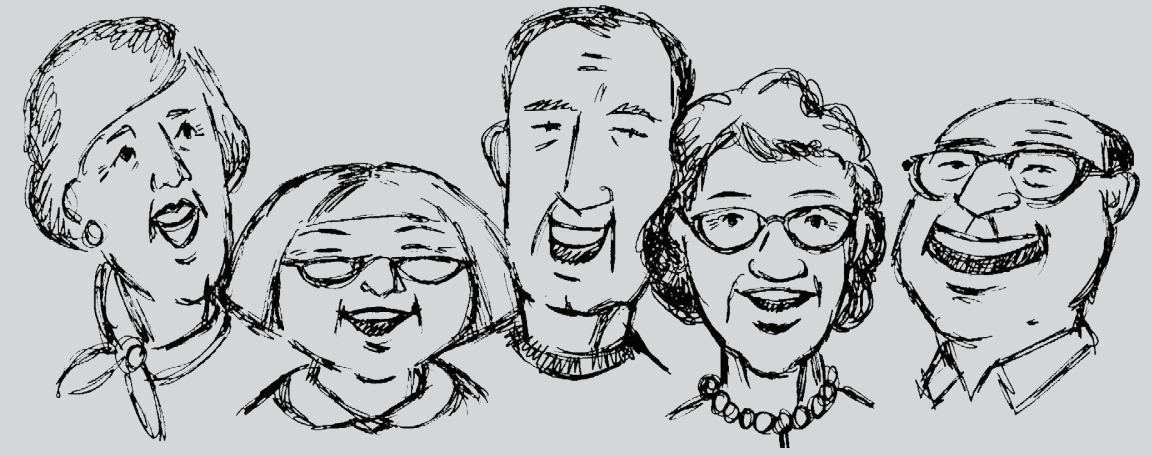

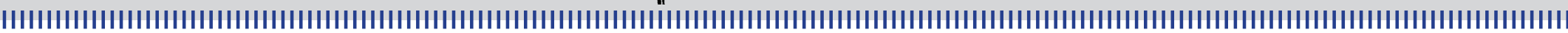

\section{WHAT COMES AFTER THE BOOM?}

baby boomers in santa maria california

a market study for People's Self Help Housing 



\section{TABLE OF CONTENTS}

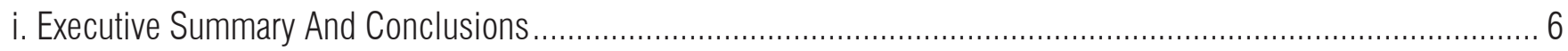

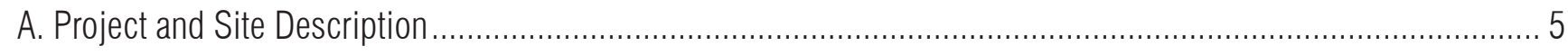

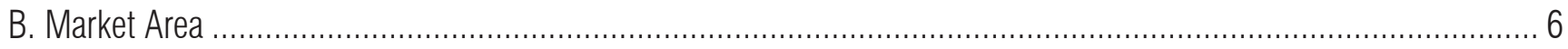

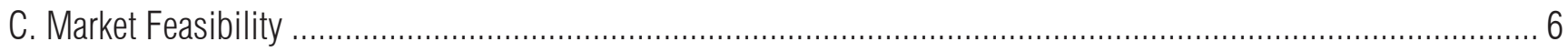

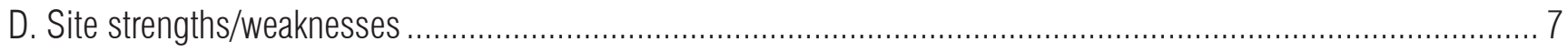

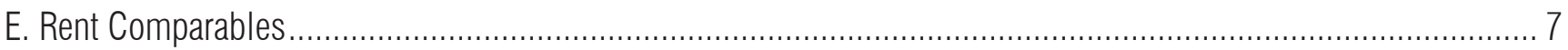

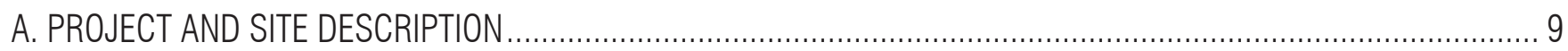

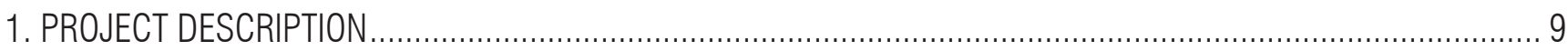

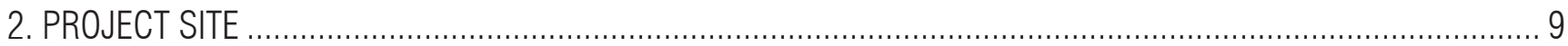

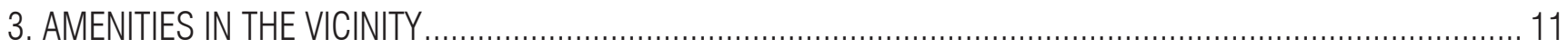

4. PHOTOGRAPHS OF SITE

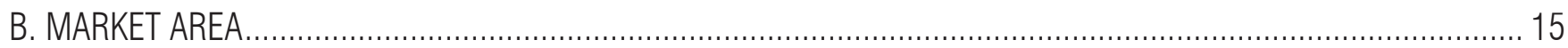

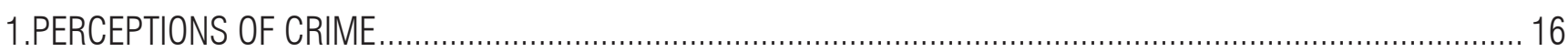

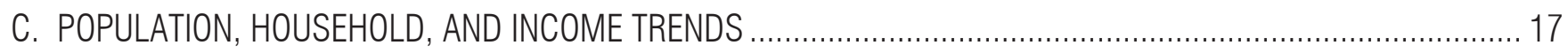

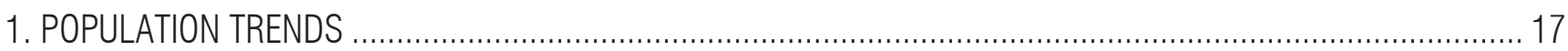

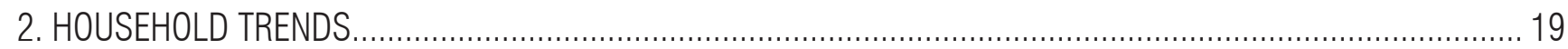

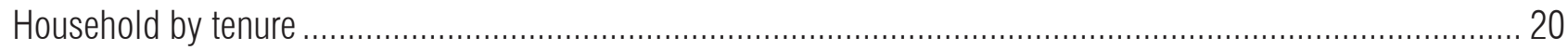

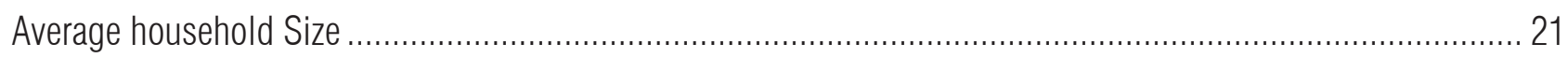

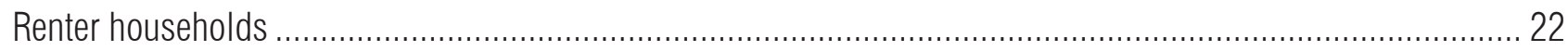

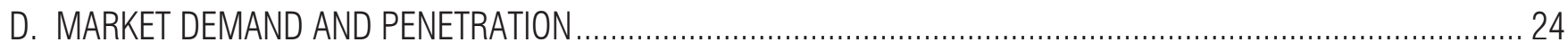

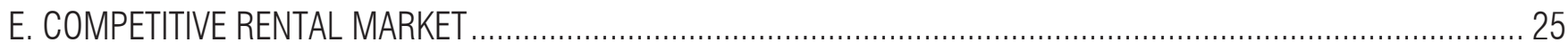

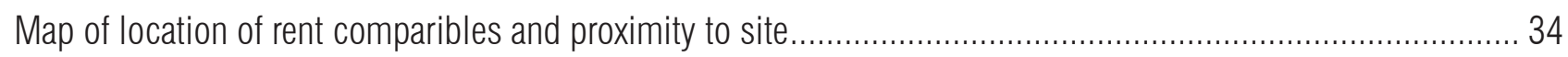

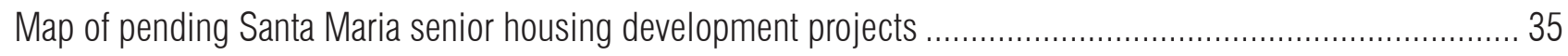




\section{LIST OF TABLES}

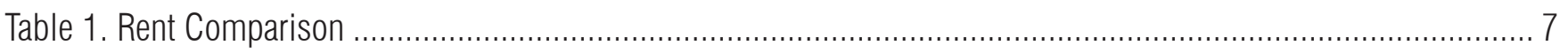

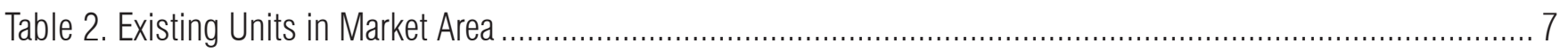

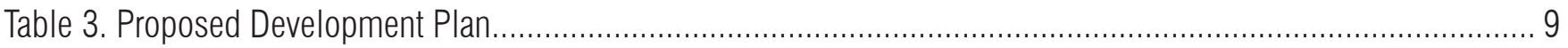

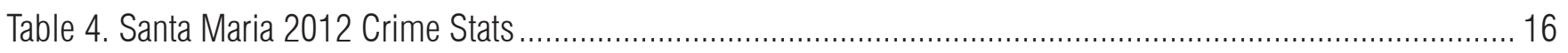

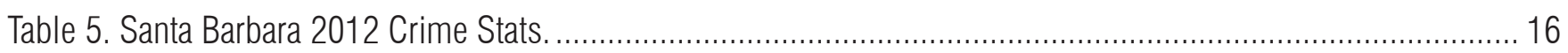

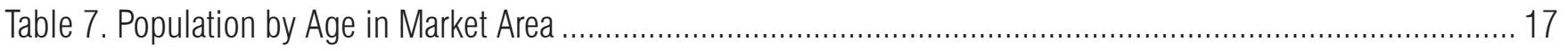

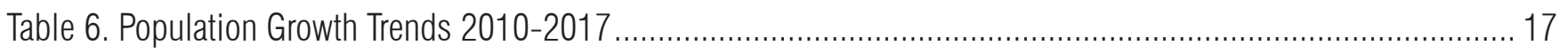

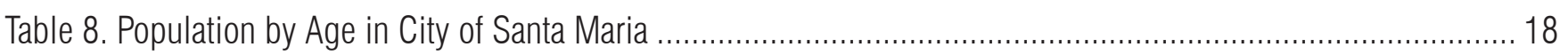

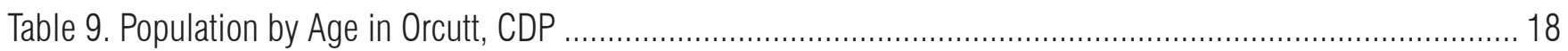

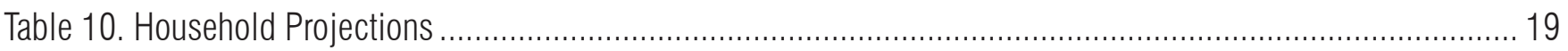

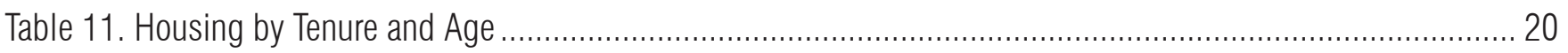

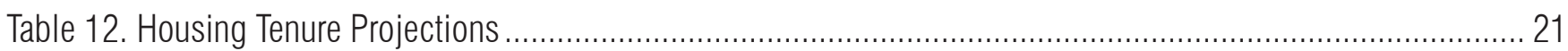

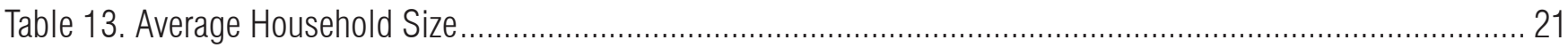

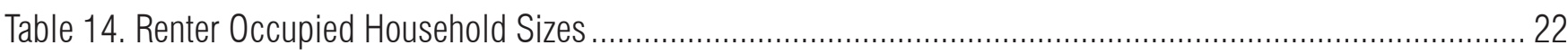

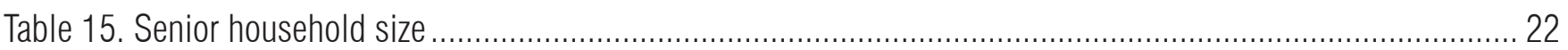

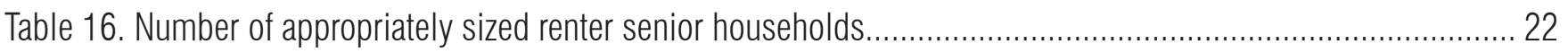

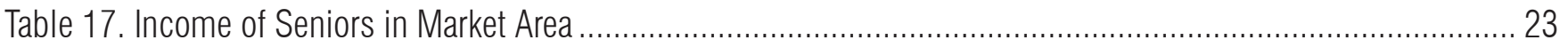

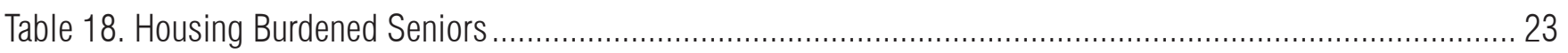

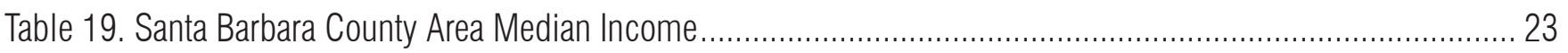

Table 20. Rent Matrix of Low-Income Senior Units in Market Area.................................................................... 36

Table 21. Rent Matrix of Market-Rate Senior Units in Market Area .................................................................... 38

\section{LIST OF FIGURES}

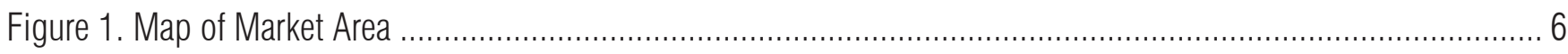

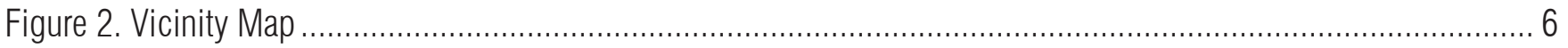

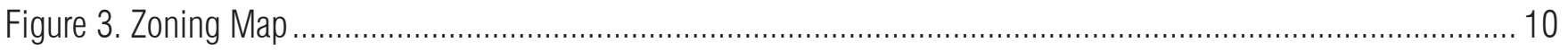

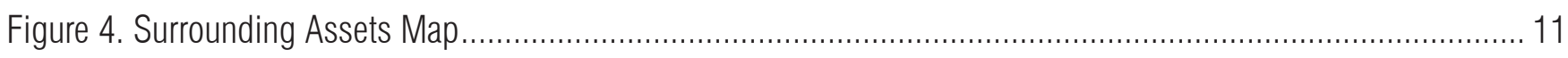

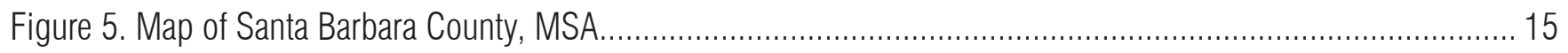

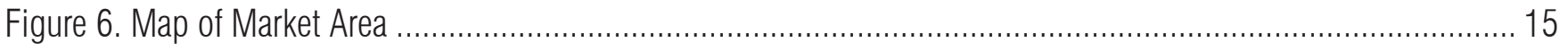

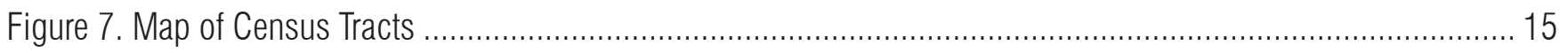

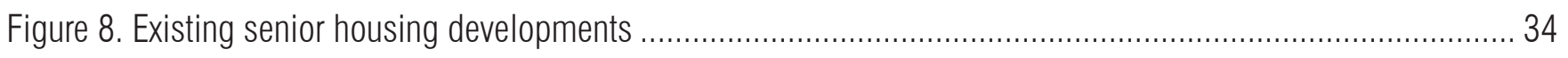

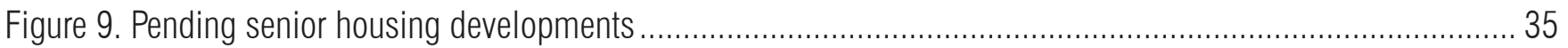




\section{EXECUTIVE SUMMARY AND CONCLUSIONS}

\section{A. Project and Site Description}

The Bethel Street Senior Housing Project includes the new construction of thirty-nine senior apartment units, to be located at 624 E. Camino Colegio (APN 125-232-002) in Santa Maria, California, Santa Barbara County, Census tract 21.02 .

The project consists of new construction of approximately thirty-six (36) one-bedroom units with approximately 600 square feet of living space and three (3) two-bedroom units with approximately 750 square feet of living space. One (1) two-bedroom unit will be designated for the on-site manager's residence. The proposed project will target senior households ( $>62$ years of age) with extremely low and very low incomes ( $<50 \%$ of AMI) in the market area which includes Santa Maria city proper and the Orcutt area. The project sponsor is People's Self Help Housing (PSHH) and the architect for the conceptual phase of the project has been Rea and Luker Architects, Inc. PSHH intends to pursue 9-percent tax credits, HOME funds, and other local funds as funding sources for the income-restricted project.

The project will consist of approximately ten separate one-story cottage-style apartments with three to five units in each building. The Bethel project is located on an approximately 5 -acre site that PSHH is currently working to split into two parcels. The proposed Lot Line Adjustment will create a parcel comprised of 2.6 acres of vacant land separate from the existing church structure at $624 \mathrm{E}$. Camino Colegio. The parcel is zoned R-1, Single Family Residential, and as such will require a zone change to allow for multi-family housing. PSHH has proposed the site be primarily accessed from Sierra Madre Avenue and has also proposed a possible secondary access-way through the church property to connect to Camino Colegio.

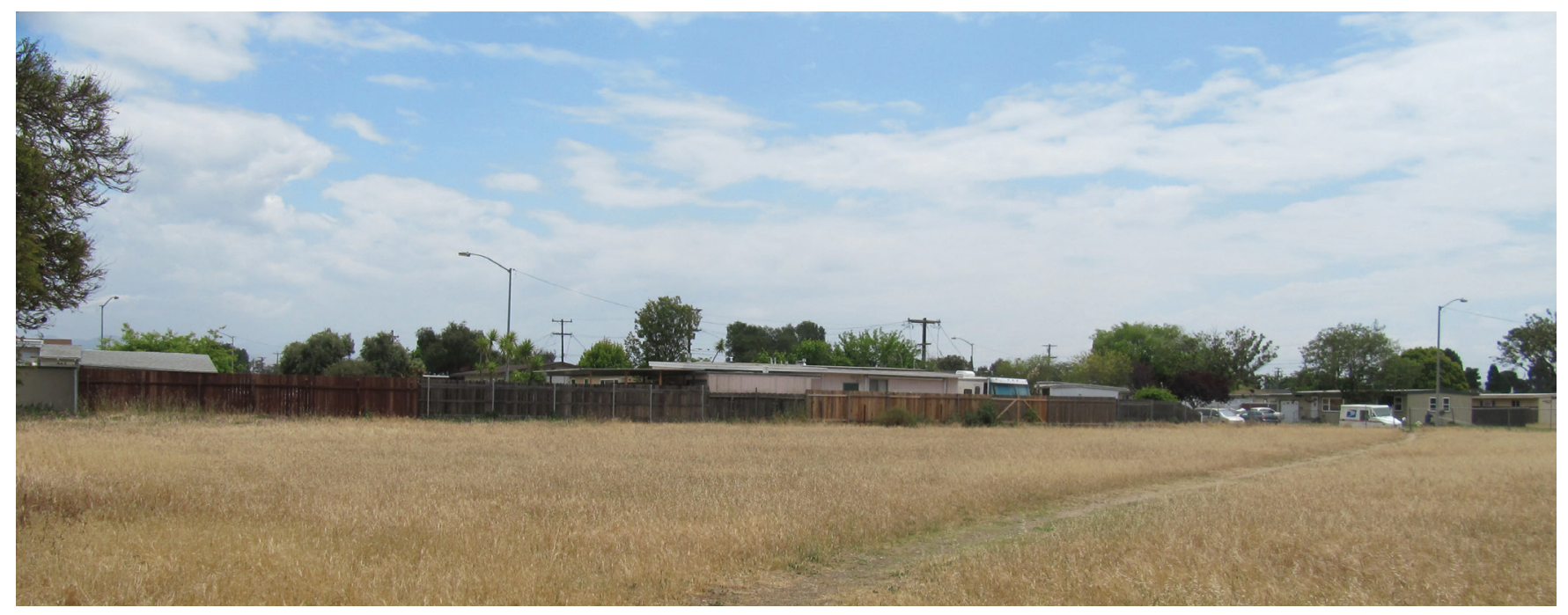

Existing vacant land at project site at 624 e. camino colegio 


\section{EXECUTIVE SUMMARY AND CONCLUSIONS}

\section{B. Market Area}

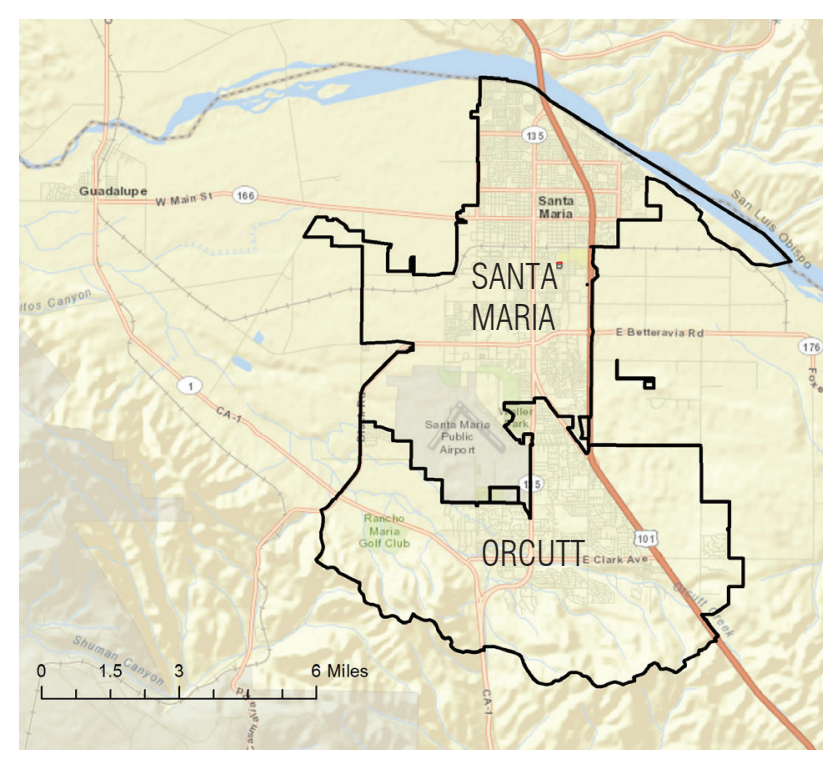

Figure 1. Map of Market Area

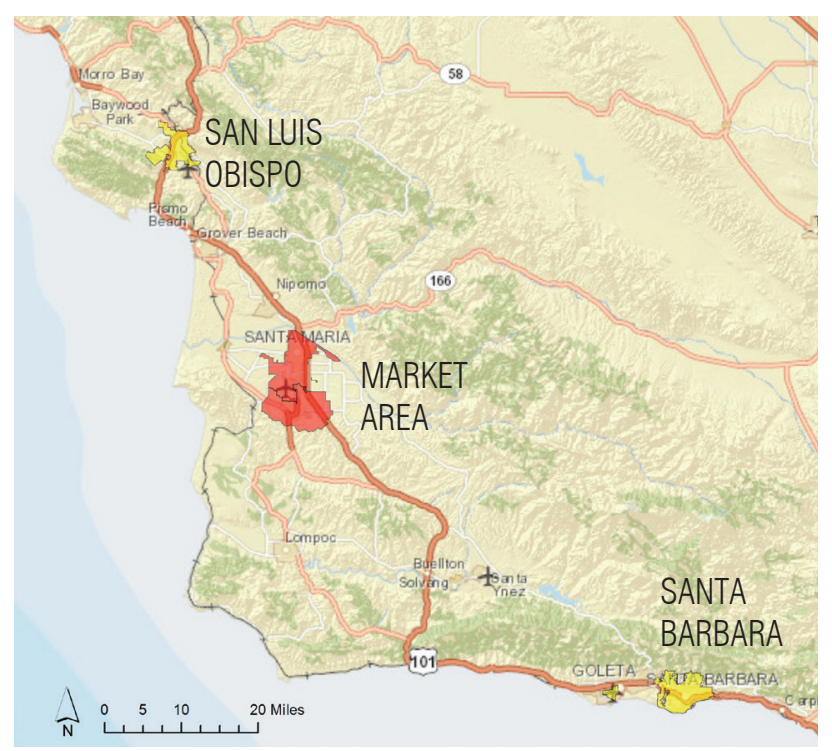

Figure 2. Vicinity Map

Included in the market area for this study is the City of Santa Maria and Census Designated Place, Orcutt (Figure 1). The market area is in between two cities with high housing costs, Santa Barbara to the south, and San Luis Obispo to the north, shown in yellow in Figure 2 above. The population of Orcutt is approximately one-fourth that of the City of Santa Maria and is often identified as the "southern portion of Santa Maria" though it is not within the city limits.

\section{Market Feasibility}

With a penetration rate of $9 \%$ (recommended range is 2.9 to $9 \%$ for feasible project), the market penetration calculation did not present a pressing demand for affordable senior housing in the market area. However, there are several invisible factors that make the proposed project feasible in the market area. First, there are little to no vacancies in the comparative affordable senior developments. Second, the theoretical demand calculation did not factor in the percentage of seniors that may move into the area in the next several years and the percentage of senior homeowners converting to affordable housing developments was conservative at $5 \%$. The demand analysis also does not take into account the number of seniors currently paying more than 30\% of their income for rent (termed "housing burdened"), more than $50 \%$ of senior renter households in the market area fit this definition. 


\section{EXECUTIVE SUMMARY AND CONCLUSIONS}

\section{Site strengths/weaknesses}

Strengths

1.0nly two of the six existing affordable senior housing developments had any vacancies, and all of the developments had a wait list (the two with vacancies had wait lists for their studio apartments).

2. The project site is a block from the Elwin Mussel Senior Center, adjacent to an elementary school and a park, a block from Marian Medical Urgent Care and other doctor's offices, and three blocks from Hancock college, a local community college.

3. This is not an area of Santa Maria perceived as a "high crime area."

\section{Weaknesses}

1.Closest grocery stores are Trader Joes and COSTCO, a half-mile walk from the project site with no easy public transit option. The closest Santa Maria Area Transit (SMAT) bus stops are the Hancock College stop on S. Bradley (.6 miles away) and the Transit Center on Boone (.5 miles away).

2. Site requires planning approval of a zone change from R-1 to R-3 which City staff may or may not support as the site is bordered to the east and south by single family residential uses.

3. Access to the site is limited with only one entrance/exit off of E. Sierra Madre Avenue. Even with the proposed fire-truck turn around, City staff may not approve the development without another access point off of a street.

\section{E. Rent Comparables}

Table 1. Rent Comparison

\begin{tabular}{|l|l|l|l|l|}
\hline Avg. rent & $\begin{array}{l}\text { Avg. Adjusted } \\
\text { Price Per SF }\end{array}$ & $\begin{array}{l}\text { Proposed Highest } \\
\text { Rents/Price Per SF }\end{array}$ & $\begin{array}{l}\% \text { Difference } \\
\text { for Rent }\end{array}$ & $\begin{array}{l}\text { Percent Difference } \\
\text { for Price Per SF }\end{array}$ \\
\hline$\$ 497$ & $\$ 1.16$ & $\$ 350 / \$ 0.61$ & $30 \%$ & $52 \%$ \\
\hline
\end{tabular}

The rent used for this comparison is the same used for the other two PSHH affordable senior developments with a rent maximum of $30 \%$ of residents' income. The proposed units have significantly lower rents than the existing affordable units. The rent for a one-bedroom is estimated to be $\$ 350$, thirty-percent less than that of the average existing affordable unit. The table below summarizes the number of existing income-restricted and market-rate rental units for seniors in the market area.

Table 2. Existing Units in Market Area

\begin{tabular}{|l|c|l|l|}
\hline UNIT TYPE & RENT-RESTRICTED & MARKET & TOTAL \\
\hline STUDI0 & $118+102+8=228$ & $40+4=44$ & 272 \\
\hline 1 BR & $121+18+26+18+40=223$ & 0 & 223 \\
\hline 2BR & 0 & $28+33=61$ & 61 \\
\hline TOTAL & 451 & 105 & 556 \\
\hline
\end{tabular}


page intentionally left blank 


\section{A. PROJECT AND SITE DESCRIPTION}

\section{PROJECT DESCRIPTION}

The project will consist of new construction of approximately thirty-six (36) one-bedroom units with approximately 600 square feet of living space and three (3) two-bedroom units with approximately 750 square feet of living space. One unit will be designated for on-site management. The proposed project will target senior households (>62 years of age) with extremely low, very low, and low incomes ( $<60 \%$ of AMI) in the market area which includes Santa Maria city proper and the Orcutt area. The project sponsor is People's Self Help Housing (PSHH) and the architect for the conceptual phase of the project has been Rea and Luker Architects, Inc. PSHH intends to pursue 9-percent tax credits, the HOME grant, and other local funds as funding sources for the income-restricted project.

The project will consist of approximately ten separate one-story cottage-style apartments with three to five units in each building (SEE APPENDIX, SITE PLANS). Proposed site amenities include a community building with manager's office, library, computer room, and laundry room. Other proposed project amenities include storage units, patios, a playground, and a gazebo. Proposed unit amenities will likely include blinds, carpet, storage and coat closets, and a kitchenette. PSHH is currently in the conceptual design phase, and as such, has not proposed specific floor plan arrangements.

Table 3. Proposed Development Plan

\begin{tabular}{|l|l|l|l|l|}
\hline $\begin{array}{l}\text { BEDROOM/ } \\
\text { BATH TYPE }\end{array}$ & \# OF UNITS & PROPOSED RENT & $\begin{array}{l}\text { UNIT SQUARE } \\
\text { FOOTAGE }\end{array}$ & $\%$ OF AREA MEDIAN INCOME \\
\hline $1 \mathrm{BR} / 1 \mathrm{BA}$ & 4 & $\$ 418$ & 575 & $<30 \%$ \\
\hline $1 \mathrm{BR} / 1 \mathrm{BA}$ & 10 & $\$ 672$ & 575 & $<45 \%$ \\
\hline $1 \mathrm{BR} / 1 \mathrm{BA}$ & 13 & $\$ 746$ & 575 & $<50 \%$ \\
\hline $1 \mathrm{BR} / 1 \mathrm{BA}$ & 10 & $\$ 896$ & 575 & $<60 \%$ \\
\hline $2 \mathrm{BR} / 1 \mathrm{BA}$ & 2 & $\$ 896$ & 750 & $<50 \%$ \\
\hline
\end{tabular}

Exception: One two-bedroom unit is reserved for on-site manager unit and has been removed from the unit count

\section{PROJECT SITE}

The Bethel project is located on an approximately 5 acre site for which PSHH has requested an entitlement from the City of Santa Maria that will split the parcel into two parcels. The proposed Lot Line Adjustment will create a parcel comprised of 2.6 acres of vacant land separate from the existing church structure at $624 \mathrm{E}$. Camino Colegio. The parcel is zoned R-1, Single Family Residential, and as such will require a zone change to allow for multi-family housing. PSHH has proposed the site be primarily accessed from Sierra Madre Avenue and has also proposed a possible secondary access-way through the church property to connect to Camino Colegio.

The site is flat with a line of pine trees running through the middle of the site as shown in the aerial view (see p. 12). The site is generally rectangular in shape, and is located directly adjacent to Bethel Lutheran Church. 


\section{A. PROJECT AND SITE DESCRIPTION}

Adjacent zoning includes Single Family Residential, Open Space, and Public Facilities to the north, Single-Family Residential to the south and east, and Public Facilities to the west. The proposed project site is marked with a star in the zoning map below (Figure 3).

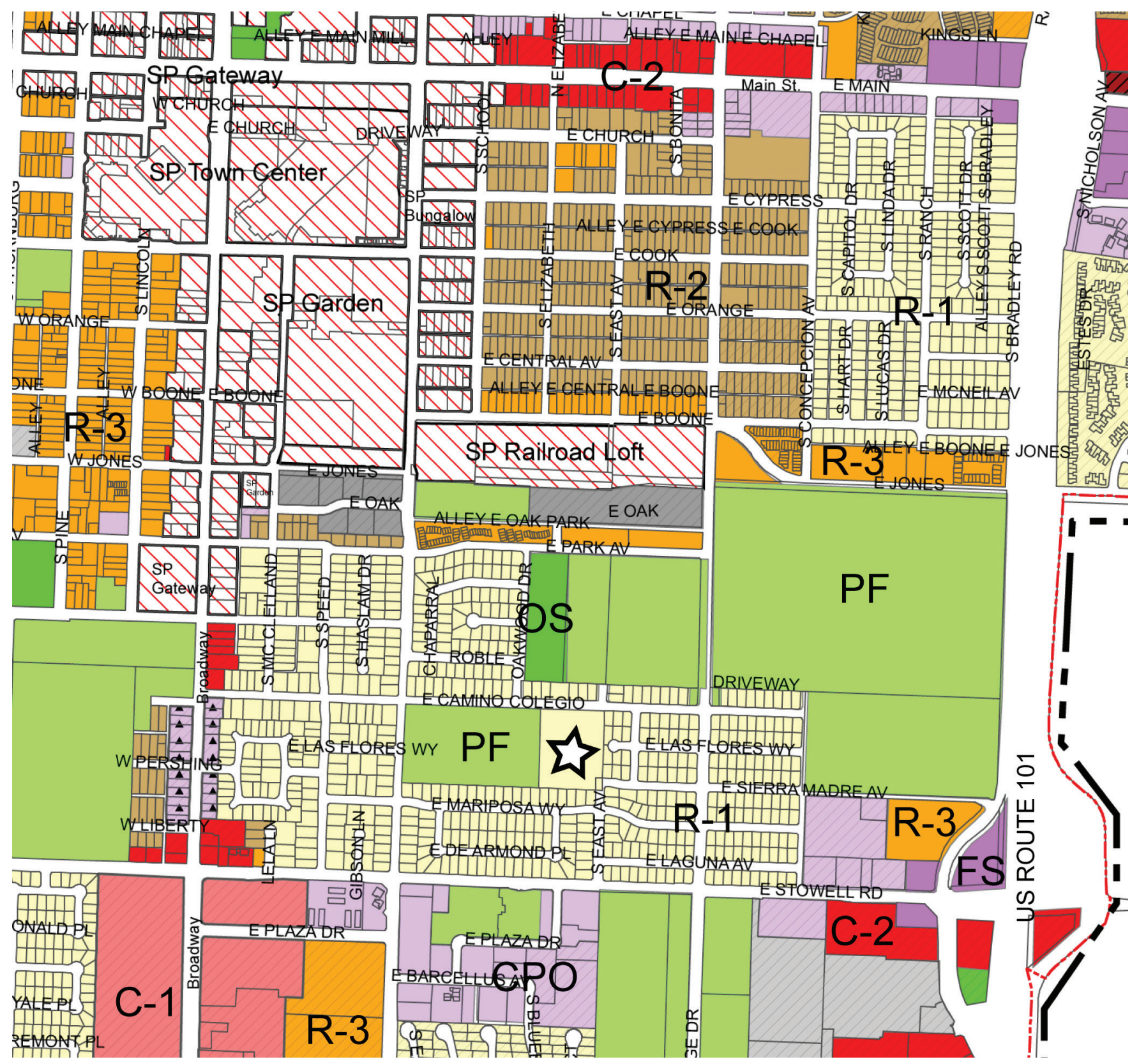

Figure 3. Zoning Map 


\section{A. PROJECT AND SITE DESCRIPTION}

3. AMENITIES IN THE VICINITY

Medical: Marian Medical Urgent Care and other various doctor's offices are located on E. Stowell Road approximately .3 miles from the site.

Grocery: The site is located approximately one half-mile from Trader Joe's and Costco grocery stores at $1303 \mathrm{~S}$. Bradley Road.

Recreation: The project site is less than .3 miles from Alice Trefts Park, a community garden at the Elwin Mussel Senior Center on Oakwood Drive, and Hancock College.

Library: The Santa Maria Public Library is located at $420 \mathrm{~S}$. Broadway, less than one mile from the project site.

Pharmacy: Hometown Pharmacy is located at 1414 S. Miller, less than .5 miles from the project site.
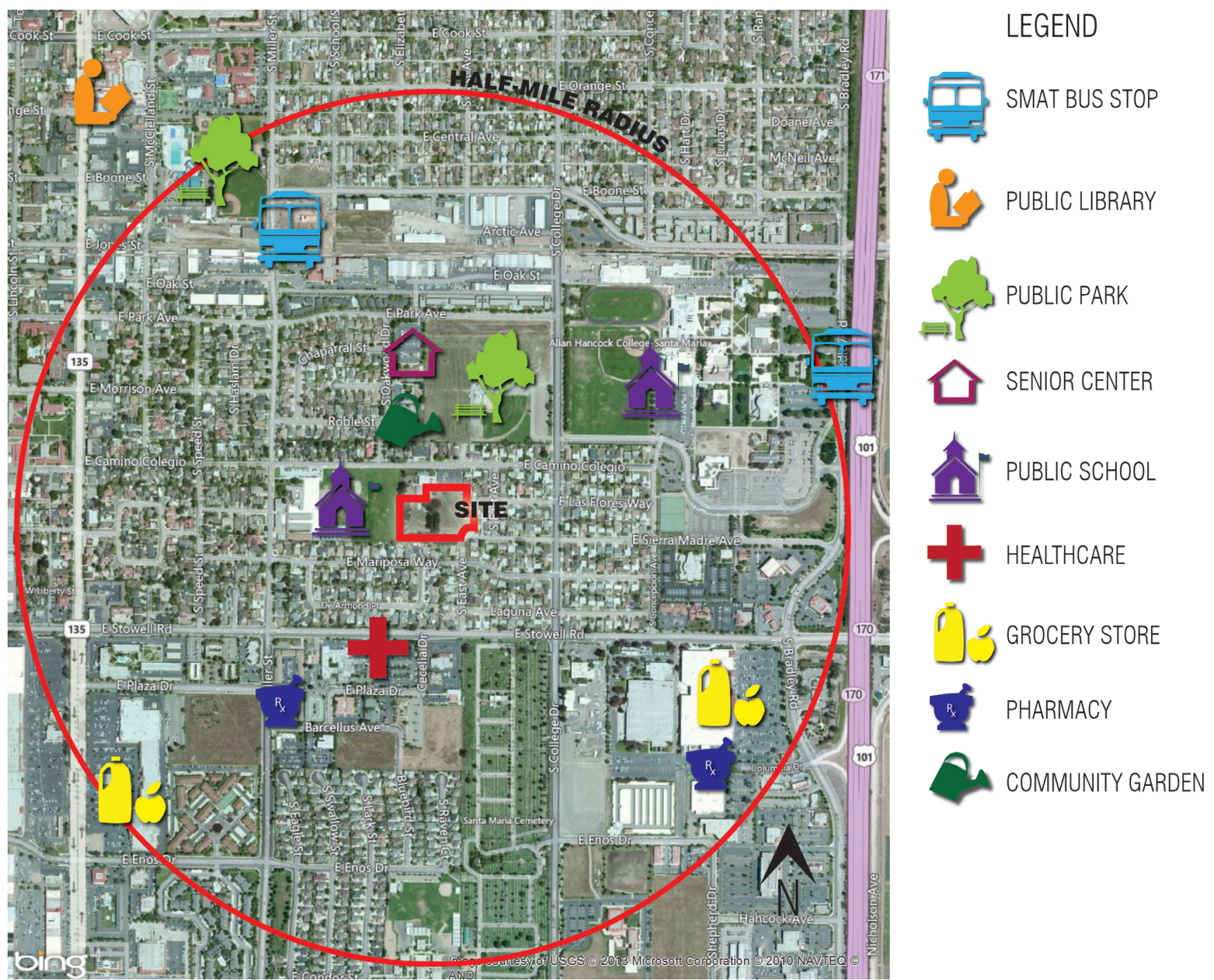

Figure 4. Surrounding Assets Map 


\section{A. PROJECT AND SITE DESCRIPTION}

The site is flat with a line of pine trees running through the middle of the site as shown in the aerial view below. The site is currently not connected to any road, but the most logical access road is Sierra Madre Avenue. The site could connect to Camino Colegio via an access easement through the church's parking lot or in the grass area to the west of the church structure; PSHH has requested evaluation of the possibility of such an easement. Assuming the Lot Line Adjustment is approved as requested, the site is 2.6 acres and is located directly adjacent to Bethel Lutheran Church.

\section{PHOTOGRAPHS OF SITE}

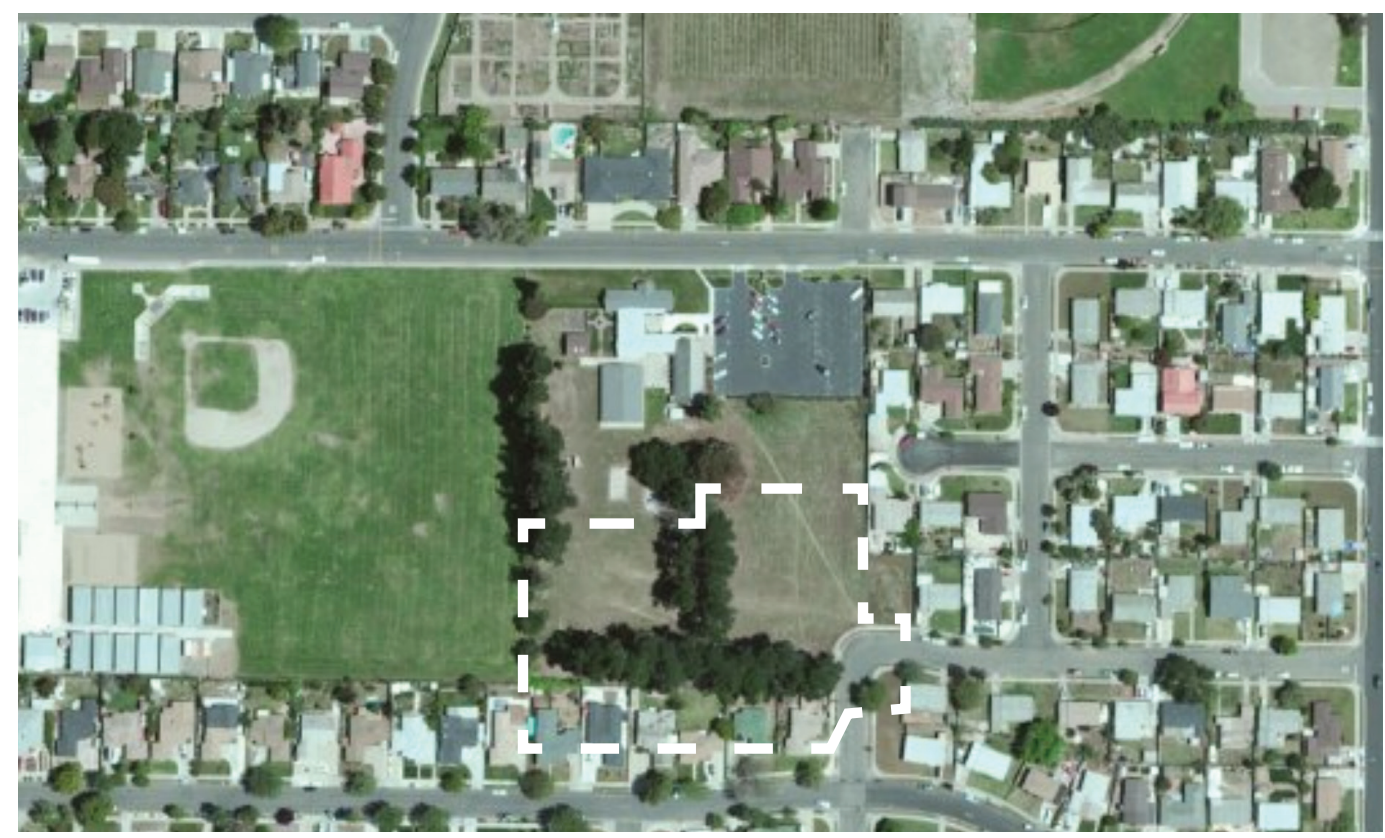

Aerial of site: the trees at the south end of the site have since been removed as they were diseased.

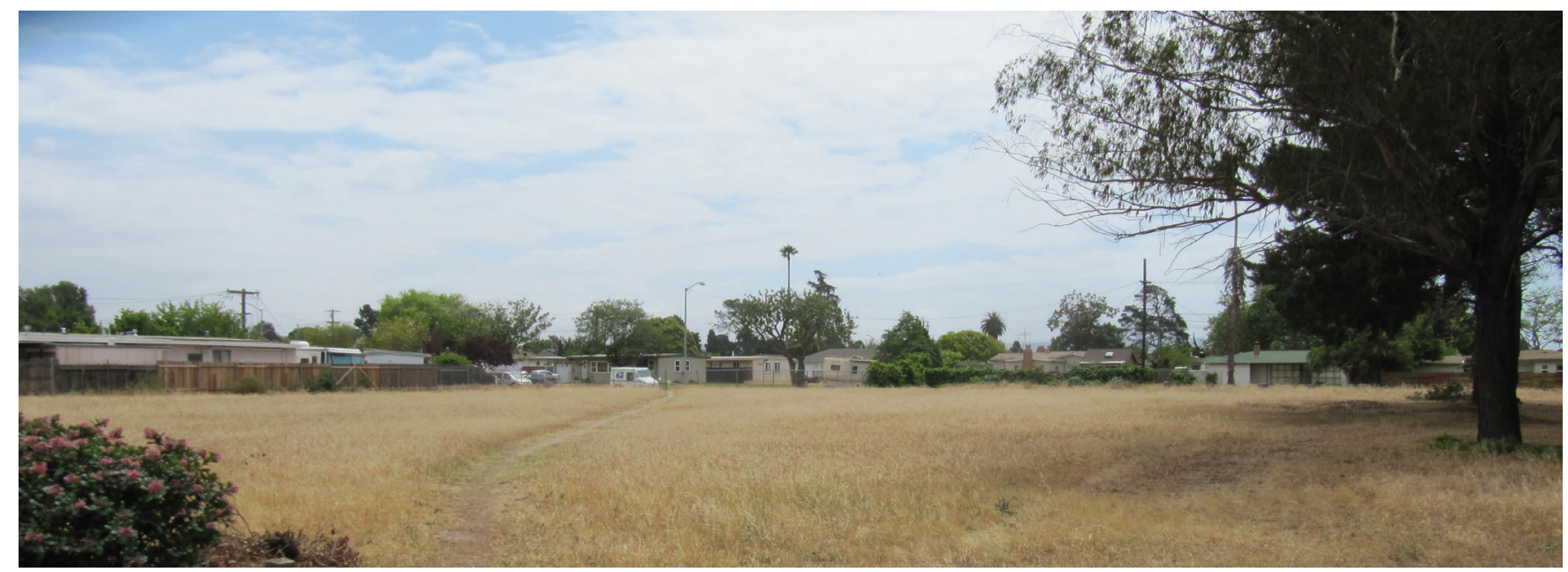

View of site looking south from the Bethel Lutheran parking lot 


\section{A. PROJECT AND SITE DESCRIPTION}

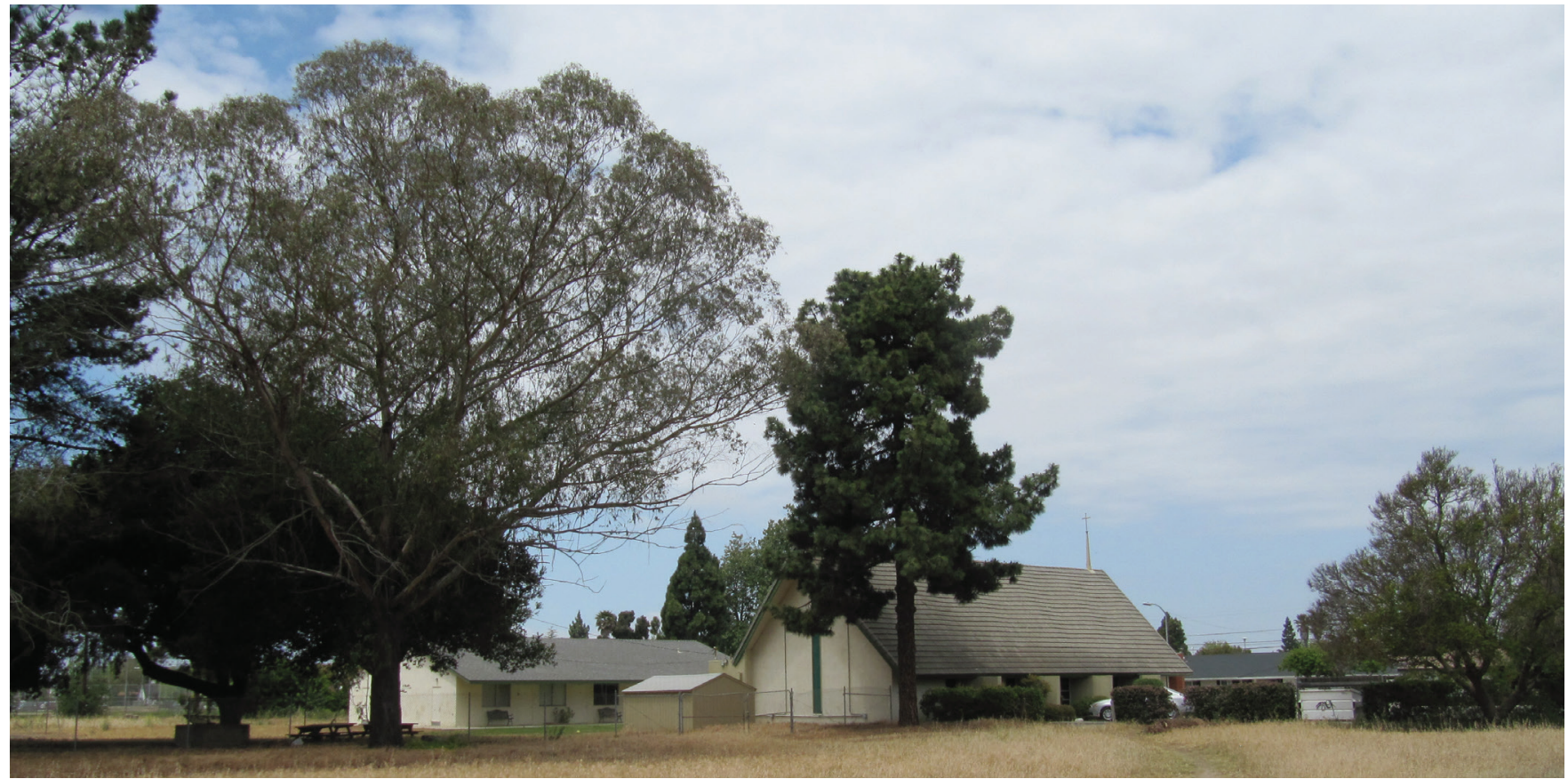

View from southern end of site, looking north

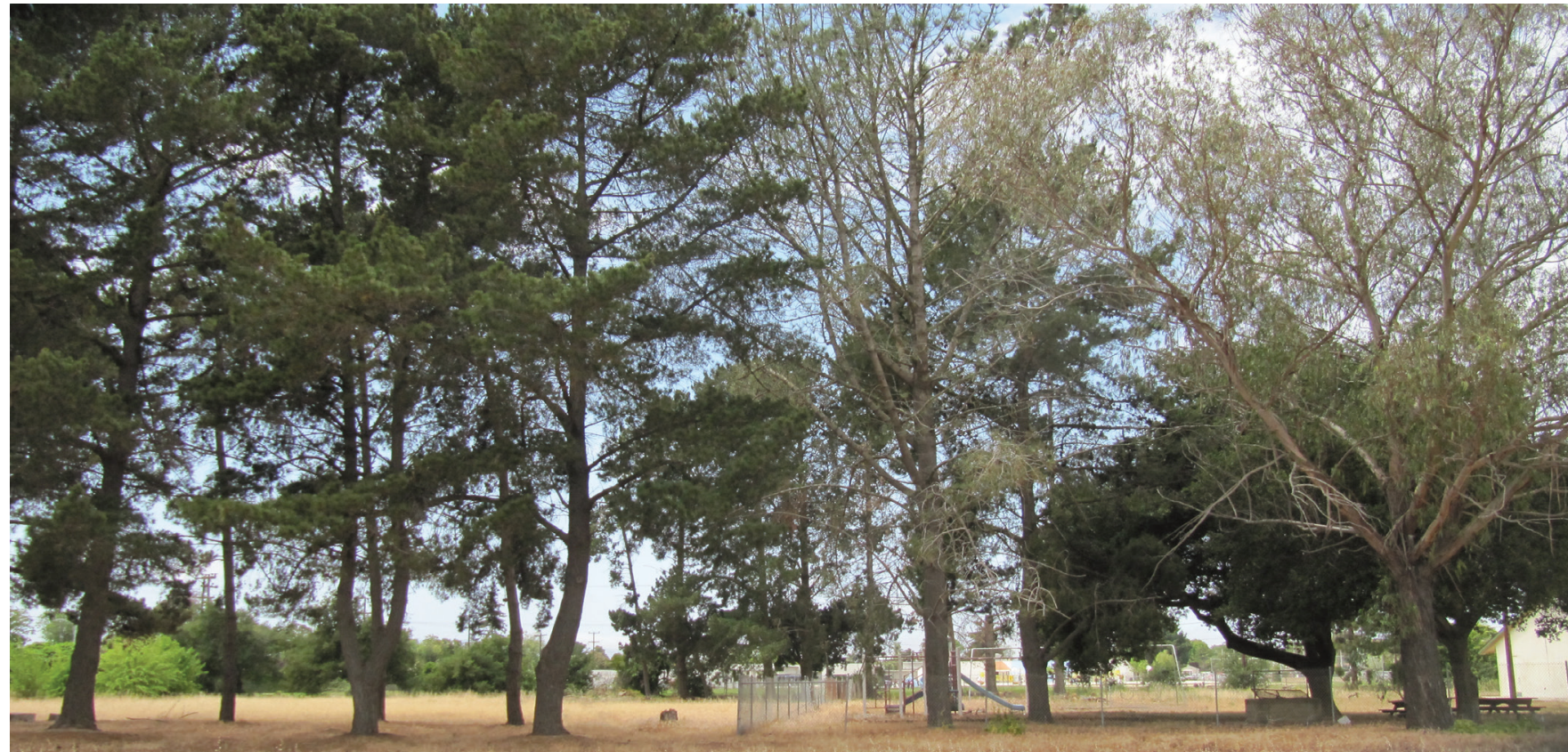

View of western portion of site, with the site's existing pine trees in the foreground and Miller Elementary School's playground in the background 


\section{A. PROJECT AND SITE DESCRIPTION}

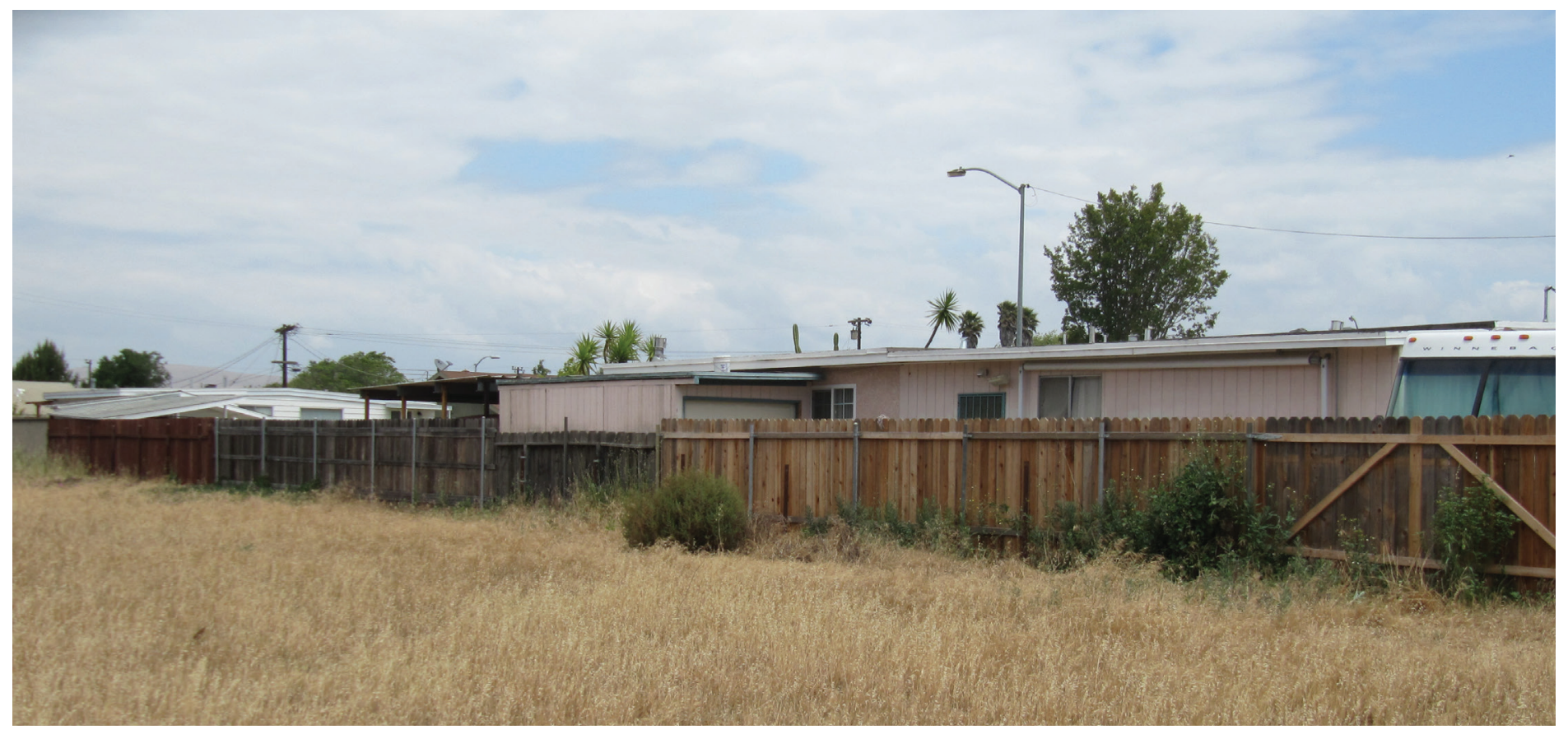

View of eastern boundary of site, existing single family residential

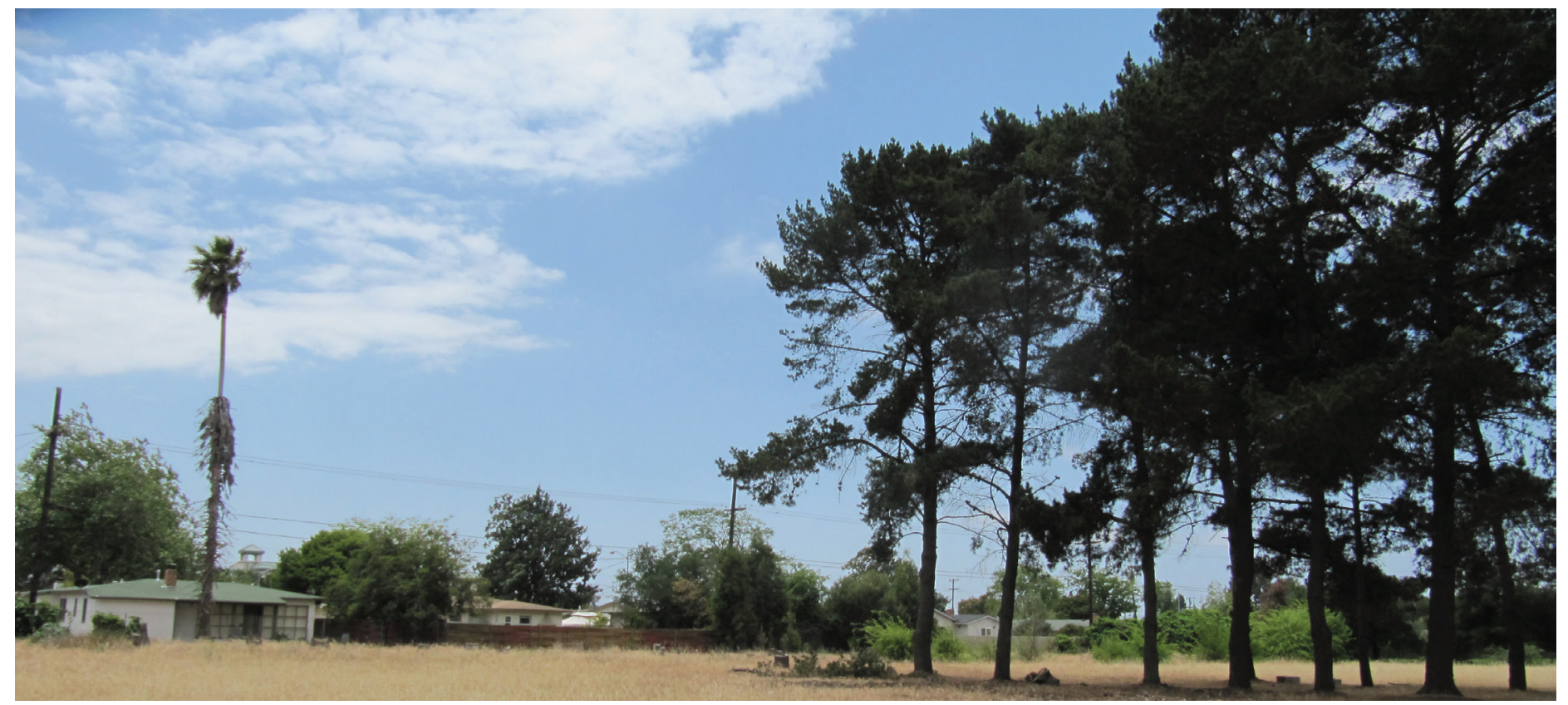

Another view of the southern portion of the site with the stand of pines in the center of the site 


\section{B. MARKET AREA}

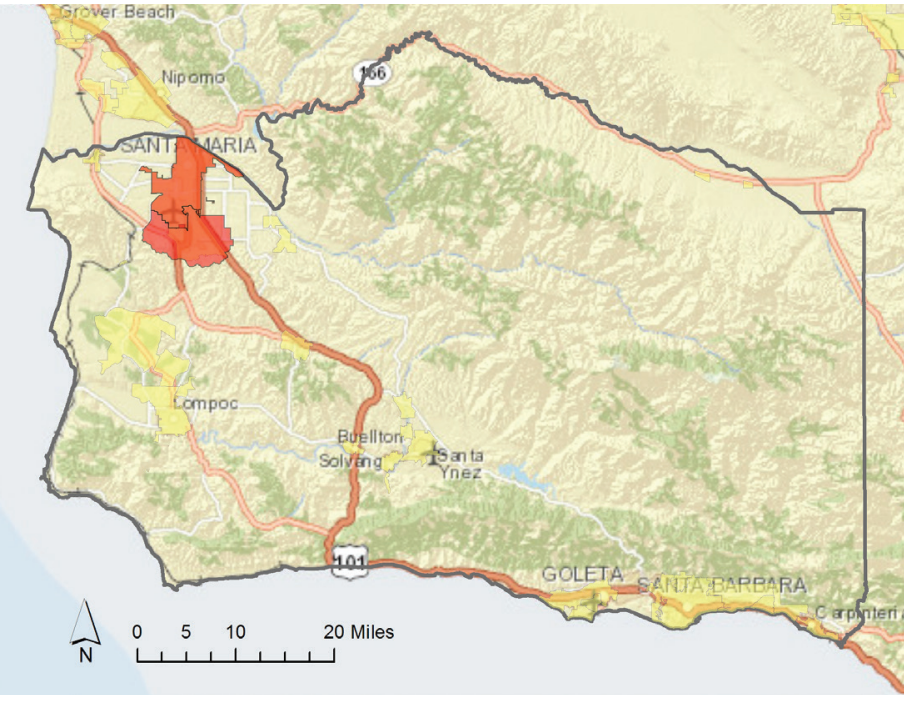

Figure 5. Map of Santa Barbara County, MSA

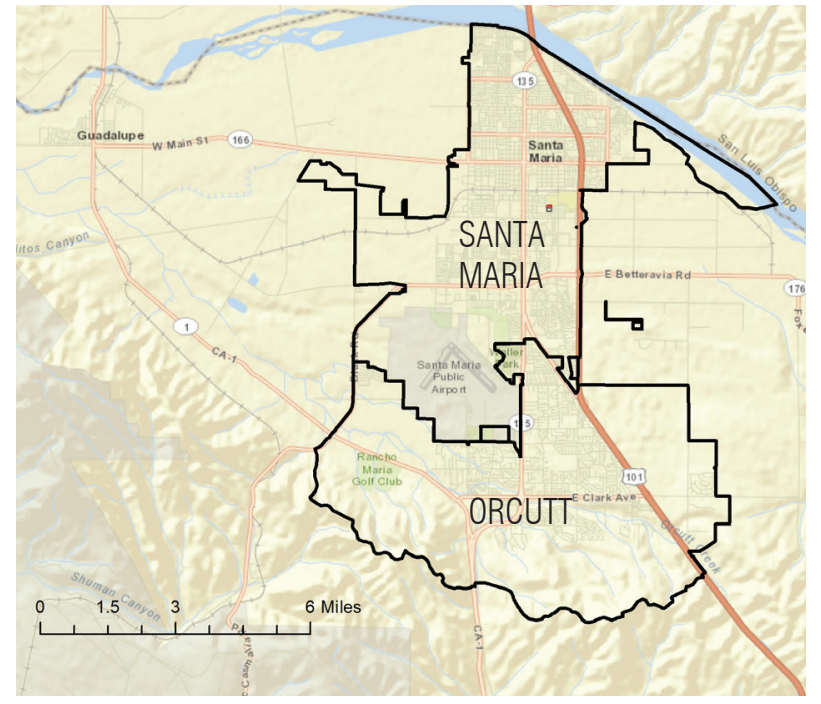

Figure 6. Map of Market Area

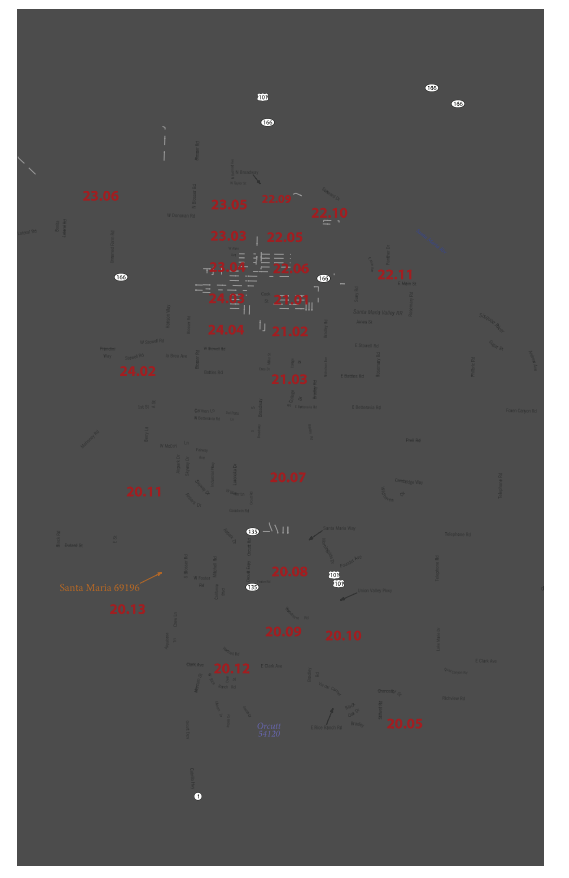

Figure 7. Map of Census Tracts
The primary market area includes the City of Santa Maria and the census designated place (CDP) to the south, Orcutt. The market area exists within the larger geographic area of Santa Barbara County, MSA: Santa Barbara-Santa Maria-Goleta. The secondary market is unnecessary to demonstrate demand because Santa Maria is surrounded by agricultural land and the next closest community is Nipomo which is more affordable than Santa Maria or Orcutt. As it is more affordable, it is unlikely that seniors from the Nipomo community would look for housing southward.

The market area for the study includes the Orcutt area because it has a higher percentage of seniors (18\%) than Santa Maria (9\%). It is likely that seniors searching for affordable housing in the bedroom community of Santa Maria would extend their search to the south. With no clear demarcation between the two communities, it is feasible that a potential resident could not realize that Orcutt was not simply the southern portion of the city limits. Orcutt also includes comparable senior developments, both market rate and low-income restricted.

The primary market area includes the census tracts shown in Figure 7. The city limits of Santa Maria are shown in orange and the bounds of Orcutt are shown in purple. 


\section{B. MARKET AREA}

Table 4. Santa Maria 2012 Crime Stats

\begin{tabular}{|l|l|}
\hline \multicolumn{2}{|c|}{ CITY OF SANTA MARIA } \\
2012 CRIME STATISTICS \\
\hline Criminal Homicide & 2 \\
\hline Forcible Rape & 21 \\
\hline Robbery & 143 \\
\hline Aggravated Assault & 529 \\
\hline Burglary & 714 \\
\hline Larceny/Theft & 1318 \\
\hline Motor Vehicle Theft & 399 \\
\hline Arson & 8 \\
\hline TOTAL & 3134 \\
\hline
\end{tabular}

City of Santa Maria Police Department
Table 5. Santa Barbara 2012 Crime Stats.

\begin{tabular}{|l|l|}
\hline \multicolumn{2}{|c|}{$\begin{array}{r}\text { CITY OF SANTA BARBARA } \\
\text { 2012 CRIME STATISTICS }\end{array}$} \\
\hline Criminal Homicide & 0 \\
\hline Forcible Rape & 44 \\
\hline Robbery & 100 \\
\hline Aggravated Assault & 279 \\
\hline Burglary & 574 \\
\hline Larceny/Theft & 2469 \\
\hline Motor Vehicle Theft & 155 \\
\hline Arson & 10 \\
\hline TOTAL & 3631 \\
\hline
\end{tabular}

City of Santa Barbara Police Department

\section{PERCEPTIONS OF CRIME}

The above tables list the crime statistics for the City of Santa Maria (2010 population of 99,553) and the City of Santa Barbara (2010 population of 88,410), the two largest cities in Santa Barbara County. The instances of crime in Santa Maria were greater than those in Santa Barbara in the following categories with the following percentages: homicides (200\%), robberies (143\%), aggravated assaults (190\%), burglaries (124\%), and motor vehicle thefts (257\%).

A popular "livability score" website indicates that Santa Maria has a violent crime rate $106 \%$ higher than the California average. The website also states that Santa Maria is safer than only $6.3 \%$ of all other cities in the country (areavibes. com). A more general internet search using the keywords "Is Santa Maria Safe?" yields forum discussions regarding the "safe" and "unsafe" areas of Santa Maria according to current and former residents. The general direction of the forums defines the northern and western Santa Maria as the "bad" parts of town and southern Santa Maria and Orcutt as the "good" parts of town. 


\section{POPULATION, HOUSEHOLD, AND INCOME TRENDS}

\section{POPULATION TRENDS} According to the 2010 Census, the population of the proposed Market Area is 128,458 persons. The projected growth trends for the market area match the projected growth rate for the county of Santa Barbara, a two-percent growth rate from 2012 to 2017. The market area accounts for a third of the projected change in the county's population from 2012 to 2017.

33\% Market area

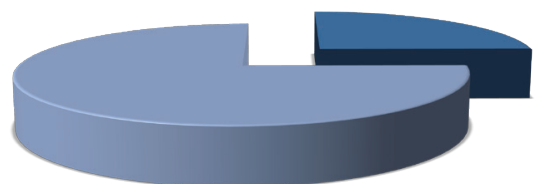

$77 \%$ Other growth in County
Table 6. Population Growth Trends 2010-2017

\begin{tabular}{|c|c|c|c|c|}
\hline \multicolumn{5}{|c|}{ POPULATION GROWTH TRENDS } \\
\hline Year & Population & Change in Pop. & $\%$ Change & Simple Annual \% Change \\
\hline \multicolumn{5}{|c|}{ Market Area } \\
\hline 2010 & 128,458 & & & \\
\hline 2012 & 128,575 & 117 & $0.09 \%$ & $0.05 \%$ \\
\hline 2017 & 131,136 & 2,561 & $1.99 \%$ & $0.40 \%$ \\
\hline \multicolumn{5}{|c|}{ City of Santa Maria } \\
\hline 2010 & 99,553 & & & \\
\hline 2012 & 99,544 & (9) & $-0.01 \%$ & $0 \%$ \\
\hline 2017 & 101,276 & 1,732 & $1.74 \%$ & $0.35 \%$ \\
\hline \multicolumn{5}{|c|}{ Santa Barbara County } \\
\hline 2010 & 423,895 & & & \\
\hline 2012 & 423,800 & -95 & $-0.02 \%$ & $-0.01 \%$ \\
\hline 2017 & 431,555 & 7,755 & $1.83 \%$ & $0.37 \%$ \\
\hline
\end{tabular}

Census 2010; ESRI 2013
POPULATION BY AGE GROUP

According to the 2010 Census, nine-percent of the City of Santa Maria's population is over the age of sixty-five. The market area has a slightly larger percentage of eleven-percent as Orcutt (included in the market area) has a greater percentage of seniors than the city proper at $20 \%$ of Orcutt's population. In the market area, the over 65 population is projected to grow at a rate $2.74 \%$ annually from 2010-2017. $((17,261-14,483) / 14,483) / 7=.0274$

Table 7. Population by Age in Market Area

\begin{tabular}{|l|l|l|l|l|l|l|}
\hline \multicolumn{7}{|c|}{ MARKET AREA- POPULATION BY AGE } \\
\hline \multirow{2}{*}{$\begin{array}{l}\text { Age } \\
\text { Cohort }\end{array}$} & \multicolumn{2}{|c|}{2010} & \multicolumn{2}{|c|}{2012} & \multicolumn{2}{c|}{2017} \\
\cline { 2 - 7 } & Population & $\%$ of Pop. & Population & $\%$ of Pop. & Population & $\%$ of Pop. \\
\hline $0-14$ & 31,697 & $25 \%$ & 31,488 & $24 \%$ & 32,264 & $25 \%$ \\
\hline $15-19$ & 11,033 & $9 \%$ & 10,524 & $8 \%$ & 10,227 & $8 \%$ \\
\hline $20-24$ & 10,071 & $8 \%$ & 10,275 & $8 \%$ & 9,466 & $7 \%$ \\
\hline $25-34$ & 18,937 & $15 \%$ & 19,275 & $15 \%$ & 19,822 & $15 \%$ \\
\hline $35-44$ & 15,706 & $12 \%$ & 15,322 & $12 \%$ & 15,395 & $12 \%$ \\
\hline $45-54$ & 15,378 & $12 \%$ & 14,945 & $12 \%$ & 14,180 & $11 \%$ \\
\hline $55-64$ & 11,153 & $9 \%$ & 11,694 & $9 \%$ & 12,520 & $10 \%$ \\
\hline $65-74$ & 6,929 & $5 \%$ & 7,384 & $6 \%$ & 9,048 & $7 \%$ \\
\hline $75-84$ & 5,169 & $4 \%$ & 5,141 & $4 \%$ & 5,483 & $4 \%$ \\
\hline $85+$ & 2,385 & $2 \%$ & 2,528 & $2 \%$ & 2,730 & $2 \%$ \\
\hline TOTAL & 128,458 & $100 \%$ & 128,576 & $100 \%$ & 131,135 & $100 \%$ \\
\hline Under 65 & 113,975 & $89 \%$ & 113,523 & $88 \%$ & 113,874 & $87 \%$ \\
\hline Over 65 & 14,483 & $11 \%$ & 15,053 & $12 \%$ & 17,261 & $13 \%$ \\
\hline Census 2010; ESRI 2013 & & & & & \\
\hline
\end{tabular}




\section{POPULATION, HOUSEHOLD, AND INCOME TRENDS}

Table 8. Population by Age in City of Santa Maria

\begin{tabular}{|l|l|l|l|l|l|l|}
\hline \multicolumn{7}{|c|}{ CITY OF SANTA MARIA- POPULATION BY AGE } \\
\hline \multirow{2}{*}{ Age Cohort } & \multicolumn{2}{|c|}{2010} & \multicolumn{2}{c|}{2012} & \multicolumn{2}{c|}{2017} \\
\cline { 2 - 7 } & Population & $\%$ of Pop. & Population & $\%$ of Pop. & Population & $\%$ of Pop. \\
\hline $0-14$ & 26,180 & $26 \%$ & 25,955 & $26 \%$ & 26,589 & $26 \%$ \\
\hline $15-19$ & 8,700 & $9 \%$ & 8,207 & $8 \%$ & 7,973 & $8 \%$ \\
\hline $20-24$ & 8,592 & $9 \%$ & 8,761 & $9 \%$ & 8,066 & $8 \%$ \\
\hline $25-34$ & 16,211 & $16 \%$ & 16,480 & $17 \%$ & 16,944 & $17 \%$ \\
\hline $35-44$ & 12,275 & $12 \%$ & 11,941 & $12 \%$ & 12,029 & $12 \%$ \\
\hline $45-54$ & 10,713 & $11 \%$ & 10,369 & $10 \%$ & 9,836 & $10 \%$ \\
\hline $55-64$ & 7,491 & $8 \%$ & 7,870 & $8 \%$ & 8,435 & $8 \%$ \\
\hline $65-74$ & 4,484 & $5 \%$ & 4,858 & $5 \%$ & 5,945 & $6 \%$ \\
\hline $75-84$ & 3,299 & $3 \%$ & 3,366 & $3 \%$ & 3,585 & $4 \%$ \\
\hline $85+$ & 1,608 & $2 \%$ & 1,737 & $2 \%$ & 1,875 & $2 \%$ \\
\hline T0TAL & 99,553 & $100 \%$ & 99,544 & $100 \%$ & 101,277 & $100 \%$ \\
\hline Under 65 & 90,162 & $91 \%$ & 89,583 & $90 \%$ & 89,872 & $89 \%$ \\
\hline Over 65 & 9,391 & $9 \%$ & 9,961 & $10 \%$ & 11,405 & $11 \%$ \\
\hline Census 2010 ESRI2013 & & & & & & \\
\hline
\end{tabular}

Table 9. Population by Age in Orcutt, CDP

\begin{tabular}{|l|l|l|l|l|l|l|}
\hline \multicolumn{7}{|c|}{ ORCUTT, CDP- POPULATION BY AGE } \\
\hline \multirow{2}{*}{ Age Cohort } & \multicolumn{2}{|c|}{2010} & \multicolumn{2}{|c|}{2012} & \multicolumn{2}{c|}{2017} \\
\cline { 2 - 7 } & Population & $\%$ of Pop. & Population & $\%$ of Pop. & Population & $\%$ of Pop. \\
\hline $0-14$ & 5,517 & $19 \%$ & 5,533 & $19 \%$ & 5,675 & $19 \%$ \\
\hline $15-19$ & 2,333 & $8 \%$ & 2,317 & $8 \%$ & 2,254 & $8 \%$ \\
\hline $20-24$ & 1,479 & $5 \%$ & 1,514 & $5 \%$ & 1,400 & $5 \%$ \\
\hline $25-34$ & 2,726 & $9 \%$ & 2,795 & $10 \%$ & 2,878 & $10 \%$ \\
\hline $35-44$ & 3,431 & $12 \%$ & 3,381 & $12 \%$ & 3,366 & $11 \%$ \\
\hline $45-54$ & 4,665 & $16 \%$ & 4,576 & $16 \%$ & 4,344 & $15 \%$ \\
\hline $55-64$ & 3,662 & $13 \%$ & 3,824 & $13 \%$ & 4,085 & $14 \%$ \\
\hline $65-74$ & 2,445 & $8 \%$ & 2,526 & $9 \%$ & 3,103 & $10 \%$ \\
\hline $75-84$ & 1,870 & $6 \%$ & 1,775 & $6 \%$ & 1,898 & $6 \%$ \\
\hline $85+$ & 777 & $3 \%$ & 791 & $3 \%$ & 855 & $3 \%$ \\
\hline TOTAL & 28,905 & $100 \%$ & 29,032 & $100 \%$ & 29,858 & $100 \%$ \\
\hline Under 65 & 23,813 & $82 \%$ & 23,940 & $82 \%$ & 24,002 & $80 \%$ \\
\hline Over 65 & 5,092 & $18 \%$ & 5,092 & $18 \%$ & 5,856 & $20 \%$ \\
\hline Census 2010; ESRI 2013 & & & & & & \\
\hline
\end{tabular}




\section{POPULATION, HOUSEHOLD, AND INCOME TRENDS}

\section{HOUSEHOLD TRENDS}

The total number of households in the market area is projected to increase at approximately the same rate (onepercent) as the county for an approximate 37,962 households by 2017. The number of households in the City of Santa Maria is also projected to grow but with a smaller percentage of .54\% increase in number of households. The City's Housing Element discusses unique housing realities in Santa Maria; the City states that the common household definition of a family of four does not address the very common practice of nuclear families joining with extended family to afford one residence in Santa Maria. These non-traditional homes may account for the lesser rate at which household growth for Santa Maria is projected than that of Orcutt and the surrounding county.

Table 10. Household Projections

\begin{tabular}{|c|c|c|c|c|}
\hline \multicolumn{5}{|c|}{ TOTAL HOUSEHOLDS } \\
\hline Year & Number & $\begin{array}{c}\text { Change in \# of } \\
\text { Households }\end{array}$ & $\%$ Change & $\begin{array}{c}\text { Simple Annual \% } \\
\text { Change }\end{array}$ \\
\hline \multicolumn{5}{|c|}{ Market Area } \\
\hline 2010 & 37,539 & & & \\
\hline 2012 & 37,590 & 51 & $0.14 \%$ & $0.07 \%$ \\
\hline 2017 & 37,962 & 372 & $1.0 \%$ & $0.20 \%$ \\
\hline \multicolumn{5}{|c|}{ City of Santa Maria } \\
\hline 2010 & 26,908 & & & \\
\hline 2012 & 26,860 & (48) & $-0.18 \%$ & $-0.09 \%$ \\
\hline 2017 & 27,005 & 145 & $0.54 \%$ & $0.11 \%$ \\
\hline \multicolumn{5}{|c|}{ Santa Barbara County } \\
\hline 2010 & 142,104 & & & \\
\hline 2012 & 142,412 & 308 & $0.22 \%$ & $0.11 \%$ \\
\hline 2017 & 143,990 & 1,578 & $1.11 \%$ & $0.22 \%$ \\
\hline
\end{tabular}

Census 2010; ESRI 2013 


\section{POPULATION, HOUSEHOLD, AND INCOME TRENDS}

\section{Household by tenure}

Approximately 32-percent or 7,080 owneroccupied housing units within the market area are occupied by persons over the age of 65. 12-percent of renter-occupied units are occupied by persons over the age of 65 . These percentages are consistent with the ratio of tenure by age for the county. The City of Santa Maria has a slightly lower percentage of elderly home-owners while Orcutt has a slightly higher percentage of elderly home-owners than the county percentages.

The general ratio for all housing units (nonelderly and elderly) for owner and renter occupied housing units for the proposed market area is projected to substantially remain at its 2010 ratio — roughly 59\% owner and 41\% renter. The housing tenure in the City of Santa Maria is more evenly split at roughly $50 \%$ owner, 50\% renter from 2010 to 2017 (Table 12, Housing Tenure Projections).
Table 11. Housing by Tenure and Age

\begin{tabular}{|c|c|c|c|}
\hline \multicolumn{4}{|c|}{ HOUSING UNITS BY TENURE AND AGE } \\
\hline \multirow{2}{*}{$\begin{array}{l}\text { Occupied } \\
\text { Housing Units }\end{array}$} & \multirow{2}{*}{ Age } & \multicolumn{2}{|c|}{2010} \\
\hline & & Number & $\%$ of TOTAL \\
\hline \multicolumn{4}{|c|}{ Market Area } \\
\hline \multirow{2}{*}{ Owner } & Non-Elderly $(<65)$ & 15,117 & $68 \%$ \\
\hline & Elderly $(>65)$ & 7,080 & $32 \%$ \\
\hline \multicolumn{3}{|c|}{ TOTAL OWNER-OCCUPIED UNITS } & 22,197 \\
\hline \multirow{2}{*}{ Renter } & Non-Elderly $(<65)$ & 13,431 & $88 \%$ \\
\hline & Elderly $(>65)$ & 1,911 & $12 \%$ \\
\hline \multicolumn{3}{|c|}{ TOTAL RENTER-OCCUPIED UNITS } & 15,342 \\
\hline \multicolumn{4}{|c|}{ City of Santa Maria } \\
\hline \multirow{2}{*}{ Owner } & Non-Elderly $(<65)$ & 9,825 & $71 \%$ \\
\hline & Elderly (>65) & 4,068 & $29 \%$ \\
\hline \multicolumn{2}{|c|}{ TOTAL OWNER-OCCUPIED UNITS } & \multicolumn{2}{|l|}{13,893} \\
\hline \multirow{2}{*}{ Renter } & Non-Elderly $(<65)$ & 11,436 & $88 \%$ \\
\hline & Elderly $(>65)$ & 1,579 & $12 \%$ \\
\hline \multicolumn{2}{|c|}{ TOTAL RENTER-OCCUPIED UNITS } & \multicolumn{2}{|l|}{13,015} \\
\hline \multicolumn{4}{|c|}{ Orcutt, Census designated place } \\
\hline \multirow{2}{*}{ Owner } & Non-Elderly $(<65)$ & 5,292 & $64 \%$ \\
\hline & Elderly $(>65)$ & 3,012 & $36 \%$ \\
\hline \multicolumn{2}{|c|}{ TOTAL OWNER-OCCUPIED UNITS } & \multicolumn{2}{|l|}{8,304} \\
\hline \multirow{2}{*}{ Renter } & Non-Elderly $(<65)$ & 1,995 & $86 \%$ \\
\hline & Elderly $(>65)$ & 332 & $14 \%$ \\
\hline \multicolumn{2}{|c|}{ TOTAL RENTER-OCCUPIED UNITS } & \multicolumn{2}{|l|}{2,327} \\
\hline \multicolumn{4}{|c|}{ Santa Barbara County } \\
\hline \multirow{2}{*}{ Owner } & Non-Elderly $(<65)$ & 48,741 & $65 \%$ \\
\hline & Elderly (>65) & 26,086 & $35 \%$ \\
\hline \multicolumn{2}{|c|}{ TOTAL OWNER-OCCUPIED UNITS } & \multicolumn{2}{|l|}{74,827} \\
\hline \multirow{2}{*}{ Renter } & Non-Elderly $(<65)$ & 58,277 & $87 \%$ \\
\hline & Elderly $(>65)$ & 9,000 & $13 \%$ \\
\hline \multicolumn{2}{|c|}{ TOTAL RENTER-OCCUPIED UNITS } & \multicolumn{2}{|l|}{67,277} \\
\hline
\end{tabular}

Census 2010; ESRI 2013 


\section{POPULATION, HOUSEHOLD, AND INCOME TRENDS}

Table 12. Housing Tenure Projections

\begin{tabular}{|l|l|l|l|l|l|l|}
\hline \multicolumn{7}{|c|}{ HOUSING TENURE PROJECTIONS } \\
\hline \multirow{2}{*}{ Occupied Housing Units } & \multicolumn{7}{|c|}{2010} & \multicolumn{2}{c|}{2012} & 2017 & \\
\cline { 2 - 7 } & Number & $\%$ of TOTAL & Number & $\%$ of TOTAL & Number & $\%$ of TOTAL \\
\hline \multicolumn{7}{|c|}{ Market Area } \\
\hline Owner & 22,197 & $59 \%$ & 21,699 & $58 \%$ & 22,392 & $59 \%$ \\
\hline Renter & 15,342 & $41 \%$ & 15,891 & $42 \%$ & 15,570 & $41 \%$ \\
\hline TOTAL & 37,539 & $100 \%$ & 37,590 & $100 \%$ & 37,962 & $100 \%$ \\
\hline \multicolumn{7}{|c|}{ City of Santa Maria } \\
\hline Owner & 13,893 & $52 \%$ & 13,464 & $50 \%$ & 13,895 & $51 \%$ \\
\hline Renter & 13,015 & $48 \%$ & 13,396 & $50 \%$ & 13,110 & $49 \%$ \\
\hline TOTAL & 26,908 & $100 \%$ & 26,860 & $100 \%$ & 27,005 & $100 \%$ \\
\hline \multicolumn{7}{|c|}{ Santa Barbara County } \\
\hline Owner & 74,827 & $53 \%$ & 72,994 & $51 \%$ & 75,208 & $52 \%$ \\
\hline Renter & 67,277 & $47 \%$ & 69,418 & $49 \%$ & 68,782 & $48 \%$ \\
\hline TOTAL & 142,104 & $100 \%$ & 142,412 & $100 \%$ & 143,990 & $100 \%$ \\
\hline
\end{tabular}

Census 2010; ESRI 2013

\section{Average Household Size}

The average household size for the county and Orcutt is slightly greater than the nationwide average of 2.58 . Santa Maria and the market area, however, have higher average household sizes. The aforementioned unique housing reality in Santa Maria (nuclear and extended families joining together under one roof) is reflected in these statistics. The pertinent question for this market study is, do seniors stay with these large familial units or do they transition to senior housing developments? The market demand analysis presented later in this study accounts for conversion of a percentage of these seniors to senior housing.
Table 13. Average Household Size

\begin{tabular}{|l|l|l|}
\hline \multicolumn{3}{|c|}{ Average Household Size } \\
\hline Place & 2012 & 2017 \\
\hline Market Area & 3.39 & 3.42 \\
\hline Santa Maria & 3.67 & 3.72 \\
\hline Orcutt & 2.68 & 2.7 \\
\hline County & 2.85 & 2.87 \\
\hline Census 2010; ESRI 2013
\end{tabular}




\section{Renter households}

The two rental household sizes that comprise the largest percentages of the occupied rental units in the market area are occupied by one person (20\%) and by more than six people (21\%). The 2009-2011 ACS Survey data as summarized in Table 15 shows that persons over 65 occupy approximately $26 \%$ of the one-person household units in the Market Area. The total number of appropriately sized elderly households is 1,421 households.
Table 14. Renter Occupied Household Sizes

\begin{tabular}{|l|r|r|}
\hline \multirow{2}{*}{$\begin{array}{c}\text { RENTER-OCCUPIED } \\
\text { HOUSEHOLD SIZE }\end{array}$} & \multicolumn{2}{|c|}{ MARKET AREA } \\
\cline { 2 - 3 } & \multicolumn{2}{|c|}{2010} \\
\cline { 2 - 3 } & Number & \% of Total \\
\hline 1 Person & 3,077 & $20 \%$ \\
\hline 2 Person & 2,626 & $17 \%$ \\
\hline 3 Person & 2,277 & $15 \%$ \\
\hline 4 Person & 2,368 & $15 \%$ \\
\hline 5 Person & 1,832 & $12 \%$ \\
\hline 6+ Person & 3,162 & $21 \%$ \\
\hline TOTAL & 15,342 & $100 \%$ \\
\hline Census 2010: ESRI2013
\end{tabular}

Table 15. Senior household size

\begin{tabular}{|l|l|l|l|}
\hline \multirow{2}{*}{$\begin{array}{c}\text { H65 RENTER OCCUPIED } \\
\text { HOUSEHOLD SIZE }\end{array}$} & \multicolumn{3}{|c|}{ MARKET AREA-2009-2011 } \\
\cline { 2 - 4 } & $\begin{array}{c}\text { Number of }>65 \\
\text { households }\end{array}$ & $\begin{array}{c}\text { Total renter households } \\
\text { with same unit size }\end{array}$ & $\begin{array}{c}\% \text { of total renter households } \\
\text { with same unit size }\end{array}$ \\
\hline 1 Person & 874 & 3,400 & $26 \%$ \\
\hline 2 Person & 547 & 12,774 & $4 \%$ \\
\hline TOTAL & 1421 & 16,174 & $9 \%$ \\
\hline
\end{tabular}

Table B25116: Tenure by Household Size; 2009-2011 ACS

Table 16. Number of appropriately sized renter senior households

\begin{tabular}{|l|l|l|}
\hline $\begin{array}{l}\text { Number of } 1 \& 2 \text { person } \\
\text { renter households }(>65)\end{array}$ & $\begin{array}{l}\text { All other renter households } \\
(>65)\end{array}$ & $\begin{array}{l}\% \text { of Appropriately-sized } \\
\text { Households }\end{array}$ \\
\hline 1421 & 1911 & $74 \%$ \\
\hline
\end{tabular}




\section{POPULATION, HOUSEHOLD, AND INCOME TRENDS}

Table 17. Income of Seniors in Market Area

\begin{tabular}{|l|l|l|l|l|}
\hline \multirow{2}{*}{$\begin{array}{c}\text { Income Range of } \\
\text { persons }>65\end{array}$} & \multicolumn{2}{|c|}{2012} & \multicolumn{2}{c|}{2017} \\
\cline { 2 - 5 } & Number & $\%$ of Total & Number & $\%$ of Total \\
\hline$<\$ 15,000$ & 2,184 & $14 \%$ & 2,395 & $14 \%$ \\
\hline$\$ 15,000-\$ 24,999$ & 2,477 & $16 \%$ & 2,342 & $14 \%$ \\
\hline$\$ 25,000-\$ 34,999$ & 2,344 & $15 \%$ & 2,125 & $13 \%$ \\
\hline$\$ 35,000-\$ 49,999$ & 2,563 & $17 \%$ & 2,605 & $16 \%$ \\
\hline$\$ 50,000-\$ 74,999$ & 3,125 & $21 \%$ & 3,531 & $21 \%$ \\
\hline$\$ 75,000-\$ 99,999$ & 1,183 & $8 \%$ & 1,916 & $11 \%$ \\
\hline$\$ 100,000-\$ 149,999$ & 879 & $6 \%$ & 1,246 & $7 \%$ \\
\hline$\$ 150,000-\$ 199,999$ & 253 & $2 \%$ & 392 & $2 \%$ \\
\hline$\$ 200,000+$ & 175 & $1 \%$ & 236 & $1 \%$ \\
\hline T0TAL & 15,183 & $100 \%$ & 16,788 & $100 \%$ \\
\hline
\end{tabular}

The number of low-income persons 65 years old and over is projected to remain the same or slightly drop by the year 2017. Approximately $57 \%$ of seniors in the market area spend more than 30-percent of their income on rent.

While this report often states "low-income seniors", the income groups eligible for the proposed project are extremely-low income (35\% AMI) to low-income (60\% AMI) as shown in Table 19 below.

Census 2010; ESRI 2013

Table 18. Housing Burdened Seniors

\begin{tabular}{|c|c|c|}
\hline \multicolumn{3}{|c|}{$\begin{array}{c}\text { HOUSING BURDENED RENTERS } \\
\text { IN MARKET AREA }\end{array}$} \\
\hline $\begin{array}{l}\text { Householder } 65 \text { years } \\
\text { and over \% of income } \\
\text { spent on rent }\end{array}$ & Number & $\begin{array}{c}\text { Total } \\
\text { Less than 20.0 percent }\end{array}$ \\
\hline 20.0 to 24.9 percent & 141 & $8 \%$ \\
\hline 25.0 to 29.9 percent & 183 & $11 \%$ \\
\hline 30.0 to 34.9 percent & 180 & $11 \%$ \\
\hline 35.0 percent or more & 777 & $46 \%$ \\
\hline Not computed & 124 & $7 \%$ \\
\hline TOTAL & 1707 & $100 \%$ \\
\hline
\end{tabular}

Census 2010
Table 19. Santa Barbara County Area Median Income

\begin{tabular}{|l|l|}
\hline \multicolumn{2}{|c|}{ SANTA BARBARA COUNTY AMI } \\
\hline $\begin{array}{l}\text { HOUSEHOLD } \\
\text { SIZE }\end{array}$ & $\begin{array}{l}\text { EXTREMELY-LOW INCOME } \\
(<30 \% \text { AMI })\end{array}$ \\
\hline 1 & $\$ 16,750$ \\
\hline 2 & $\$ 19,150$ \\
\hline \multicolumn{2}{|c|}{ VERY-LOW INCOME (50\%) } \\
\hline 1 & $\$ 27,900$ \\
\hline 2 & $\$ 31,850$ \\
\hline \multicolumn{2}{|c|}{ LOW INCOME (60\% AMI) } \\
\hline 1 & $\$ 33,480$ \\
\hline 2 & $\$ 38,220$ \\
\hline
\end{tabular}

County of Santa Barbara 


\section{MARKET DEMAND AND PENETRATION}

A. Demand from existing renter households:

1. Number of existing senior ( $>65$ households) in market area: 8,911

2. Number of senior renters in market area: $8,911 \times 21.25 \%=1,911$

3. Number of appropriately sized renter households ( 1 and 2 person): 1,421

4. Number of income-qualified renter households: $1,421 \times 50 \%=710.5$

${ }^{*} 50 \%$ includes all seniors with incomes $<60 \%$ AMI

5. Turnover rate: $710.5 \times 10 \%=71.05$

* Turnover rate based on feedback from property managers in housing survey, see p. 25

6. Estimated annual demand from existing rental households: $710.5-71.05=639.45$

B. Demand from new households:

1. Number of new, additional renter households by 2017 : $228 \times .12=27.36$ over 65

households (The twelve percent was derived from ESRI data for 2010 elderly

renter households and kept at a constant rate)

2. Estimated annual growth (2010-2017): 27.36/7 =4 households

3. Number of appropriately sized households: $4 \times .74=3$

4. Number of income-qualified renter households (2017):3 $\times 48 \%=1$

5. Estimated annual demand from new households: 1

C. Demand from existing senior home-owners

1. Number of existing senior households: 7,080

2. Number of one-and-two-person senior households: 2291

3. Number of income-qualified household: $2291 \times 50 \%=1145.5$

4. Conversion rate (estimated potential rate of senior homeowners that move into affordable rental units in a year): $1145.5 \times 5 \%=$

5. Estimated annual demand from existing senior homeowner households: 57

D. Total Theoretical Demand: Existing $639.45+1+57=697.45$

E. Penetration Estimate

Proposed Units + Pending Units + Vacant Competitive Units)/Theoretical Demand $38+0+8 / 697.45=6.6 \%$ 


\section{E. COMPETITIVE RENTAL MARKET}

\begin{tabular}{|l|l|l|l|}
\hline NAME & Rancho Gardens & DATE & May 8, 2013 \\
\hline ADDRESS & 1414 N. Broadway & TOTAL UNITS & 118 \\
\hline CITY & Santa Maria & CONDITION & Fair \\
\hline MANAGER & Martha Marfori & YEAR BUILT & Ren. in 2000 \\
\hline TELEPHONE & $805-349-8722$ & BLDG. STYLE & one \& two-story \\
\hline
\end{tabular}

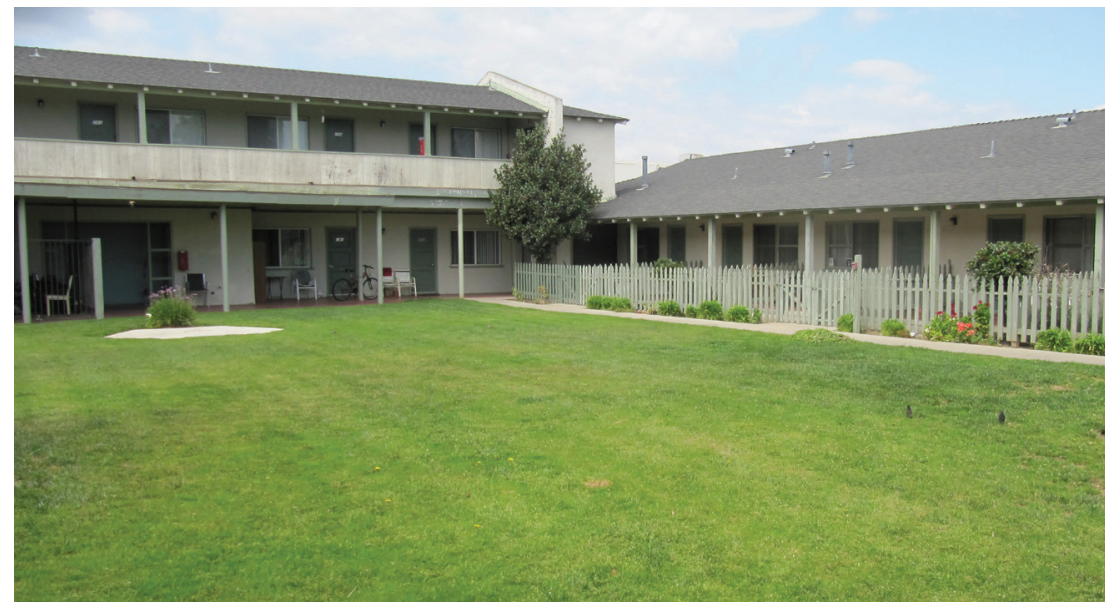

- Property was formerly the Turtle Inn and was renovated and converted to senior housing in 2000

- Income and Age Restricted$>62$ and $<50 \%$ AMI

- Rent includes all utilities plus cable and monthly activities

\begin{tabular}{|l|c|l|l|l|l|}
\hline BR/BA & \# UNITS & BASE RENT & SQ. FO0TAGE & RENT/S.F. & VACANT \\
\hline STUDI0-1 BA & 118 & $\$ 675$ & $230-400$ & $\$ 1.69-\$ 2.94$ & 0 \\
\hline
\end{tabular}

\begin{tabular}{|l|l|l|l|l|l|l|l|l|l|}
\hline \multicolumn{4}{|c|}{ UNIT AMENITIES } & \multicolumn{4}{c|}{ PROJECT AMENITIES } & \multicolumn{2}{c|}{ TENANT PAYS } \\
\hline Central Heat & X & Refrigerator & X & Community Room & X & Business Center & & Electricity & \\
\hline Central AC & X & Stove/Oven & X & Swimming Pool & & Car Wash Area & & Heat (G or E) & \\
\hline Blinds & X & Dishwasher & & Spa/Jacuzzi & & Gated Security & & Hot Water & \\
\hline Carpet & X & Garbage Disposal & & Exercise Room & & Security Patrol & & Cooking (G or E) & \\
\hline Ceiling Fan & & Microwave & & Picnic Area & X & Security Camera & & TV (C or S) & \\
\hline Skylight & & Washer/Dryer & & Playground & & & & Water & \\
\hline Storage Closet & X & W/D Hook-ups & & Tennis Court & & & & Sewer & \\
\hline Coat Closet & & Surface Parking & X & Basketball Court & & & & Trash & \\
\hline Walk-In Closet & & Carport & & Volleyball Court & & & & & \\
\hline Fireplace & & Underground Parking & & On-site Manager & X & & & & \\
\hline Patio & X & Garage & & Laundry Room & X & & & & \\
\hline Balcony & & Parking Garage & & Computer Room & & & & & \\
\hline
\end{tabular}




\section{E. COMPETITIVE RENTAL MARKET}

\begin{tabular}{|c|c|c|c|}
\hline NAME & Union Plaza Senior Apartments & DATE & May 8, 2013 \\
\hline ADDRESS & 120 N. Broadway & TOTAL UNITS & 121 \\
\hline CITY & Santa Maria & CONDITION & Fair \\
\hline MANAGER & Terry Krelle & YEAR BUILT & 1975 \\
\hline TELEPHONE & $805-922-5226$ & BLDG. STYLE & sev \\
\hline
\end{tabular}

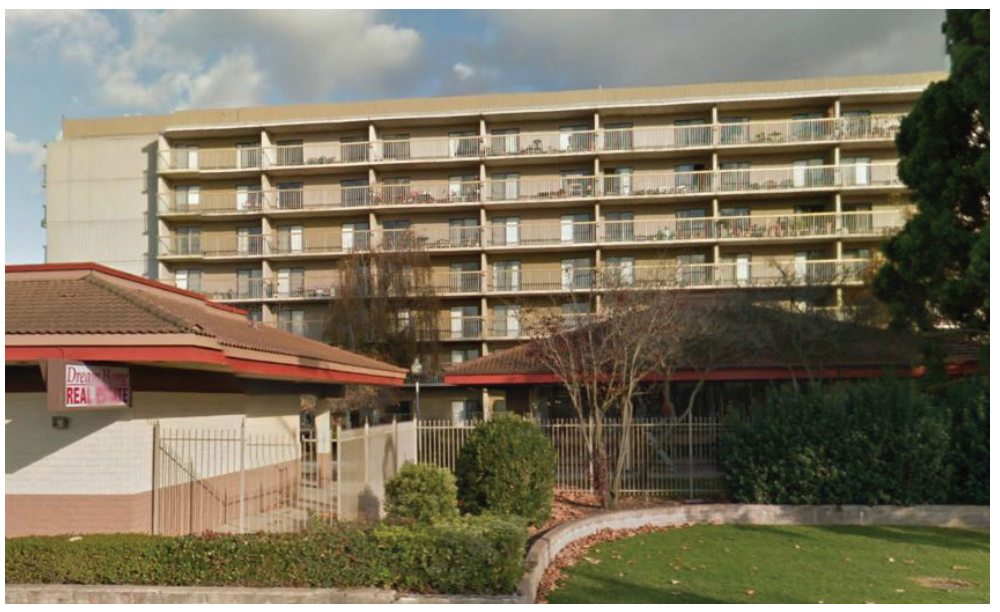

- Section 8-project based property with income and age limits: $>62$ and $<50 \%$ AMI

- Rent is $30 \%$ of income

- The property manager stated that rent paid by residents varies from $\$ 25$ to $\$ 400$ but stated $\$ 250$ would be a good average base rent.

\begin{tabular}{|l|c|l|l|l|l|}
\hline BR/BA & \# UNITS & BASE RENT & SQ. FOOTAGE & RENT/S.F. & VACANT \\
\hline 1 BR-1 BA & 121 & $\$ 250$ & 550 & $\$ 0.75$ & 0 \\
\hline
\end{tabular}

\begin{tabular}{|l|l|l|l|l|l|l|l|l|l|}
\hline \multicolumn{4}{|c|}{ UNIT AMENITIES } & \multicolumn{4}{c|}{ PROJECT AMENITIES } & \multicolumn{2}{c|}{ TENANT PAYS } \\
\hline Central Heat & X & Refrigerator & X & Community Room & X & Business Center & & Electricity & X \\
\hline Central AC & & Stove/Oven & X & Swimming Pool & & Car Wash Area & & Heat (G or E) & E \\
\hline Blinds & X & Dishwasher & & Spa/Jacuzzi & & Gated Security & & Hot Water & E \\
\hline Carpet & X & Garbage Disposal & X & Exercise Room & & Security Patrol & & Cooking (G or E) & E \\
\hline Ceiling Fan & & Microwave & & Picnic Area & X & Security Camera & & TV (C or S) & C \\
\hline Skylight & & Washer/Dryer & & Playground & & & & Water & \\
\hline Storage Closet & X & W/D Hook-ups & & Tennis Court & & & & Sewer & \\
\hline Coat Closet & & Surface Parking & X & Basketball Court & & & & Trash & \\
\hline Walk-In Closet & & Carport & X & Volleyball Court & & & & & \\
\hline Fireplace & & Underground Parking & & On-site Manager & X & & & & \\
\hline Patio & & Garage & & Laundry Room & X & & & & \\
\hline Balcony & X & Parking Garage & & Computer Room & & & & & \\
\hline
\end{tabular}




\section{E. COMPETITIVE RENTAL MARKET}

\begin{tabular}{|l|l|l|l|}
\hline NAME & Vandenberg Senior Residence & DATE & May 8, 2013 \\
\hline ADDRESS & 1316 S. Broadway & TOTAL UNITS & 120 \\
\hline CITY & Santa Maria & CONDITION & Good \\
\hline MANAGER & Bill Graham & YEAR BUILT & ren. 1990s \\
\hline TELEPHONE & $805-925-6373$ & BLDG. STYLE & three-story \\
\hline
\end{tabular}

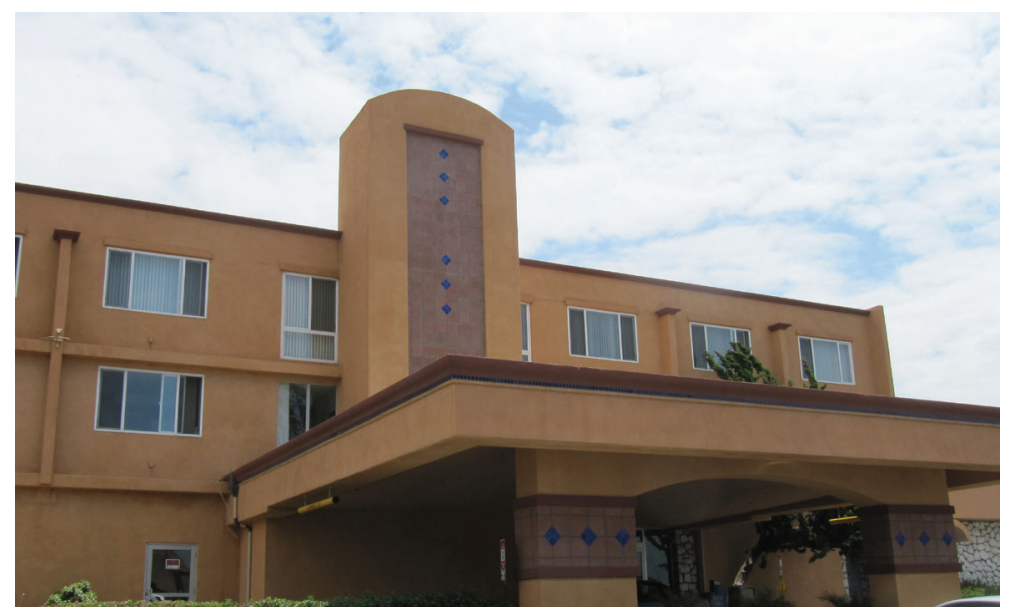

- Income and age-restricted units: $>55$ years of age and less than $60 \%$ of the AMl for Santa Barbara County

- 15 of the studios include patios and an increased rent- none are available

- Former hotel renovated in the early 1990's. The residence appears to be in good condition.

\begin{tabular}{|l|c|l|l|l|l|}
\hline BR/BA & \# UNITS & BASE RENT & SQ. FOOTAGE & RENT/S.F. & VACANT \\
\hline STUDI0-1 BA & 102 & 575 & 350 & $\$ 1.64$ & 3 \\
\hline 1 BR-1 BA & 18 & 780 & 700 & $\$ 1.11$ & 5 \\
\hline
\end{tabular}

\begin{tabular}{|l|l|l|l|l|l|l|l|l|l|}
\hline \multicolumn{4}{|c|}{ UNIT AMENITIES } & \multicolumn{4}{c|}{ PROJECT AMENITIES } & \multicolumn{2}{c|}{ TENANT PAYS } \\
\hline Central Heat & X & Refrigerator & X & Community Room & X & Business Center & & Electricity & X \\
\hline Central AC & & Stove/Oven & X & Swimming Pool & X & Car Wash Area & & Heat (G or E) & E \\
\hline Blinds & X & Dishwasher & & Spa/Jacuzzi & X & Gated Security & & Hot Water & E \\
\hline Carpet & X & Garbage Disposal & X & Exercise Room & X & Security Patrol & & Cooking (G or E) & E \\
\hline Ceiling Fan & & Microwave & X & Picnic Area & X & Security Camera & & TV (C or S) & C \\
\hline Skylight & & Washer/Dryer & & Playground & & & & Water & \\
\hline Storage Closet & X & W/D Hook-ups & & Tennis Court & & & & Sewer & \\
\hline Coat Closet & & Surface Parking & X & Basketball Court & & & & Trash & \\
\hline Walk-In Closet & & Carport & X & Volleyball Court & & & & & \\
\hline Fireplace & & Underground Parking & & On-site Manager & X & & & & \\
\hline Patio & & Garage & & Laundry Room & X & & & & \\
\hline Balcony & & Parking Garage & & Computer Room & & & & & \\
\hline
\end{tabular}




\section{E. COMPETITIVE RENTAL MARKET}

\begin{tabular}{|l|l|l|l|}
\hline 4AME & Valentine Court I & DATE & May 8, 2013 \\
\hline ADDRESS & 280 Newlove Drive & TOTAL UNITS & 34 \\
\hline CITY & Santa Maria & CONDITION & Good \\
\hline MANAGER & Chris Morrison & YEAR BUILT & 1990 \\
\hline TELEPHONE & $805-925-6373$ & BLDG. STYLE & one-story \\
\hline
\end{tabular}

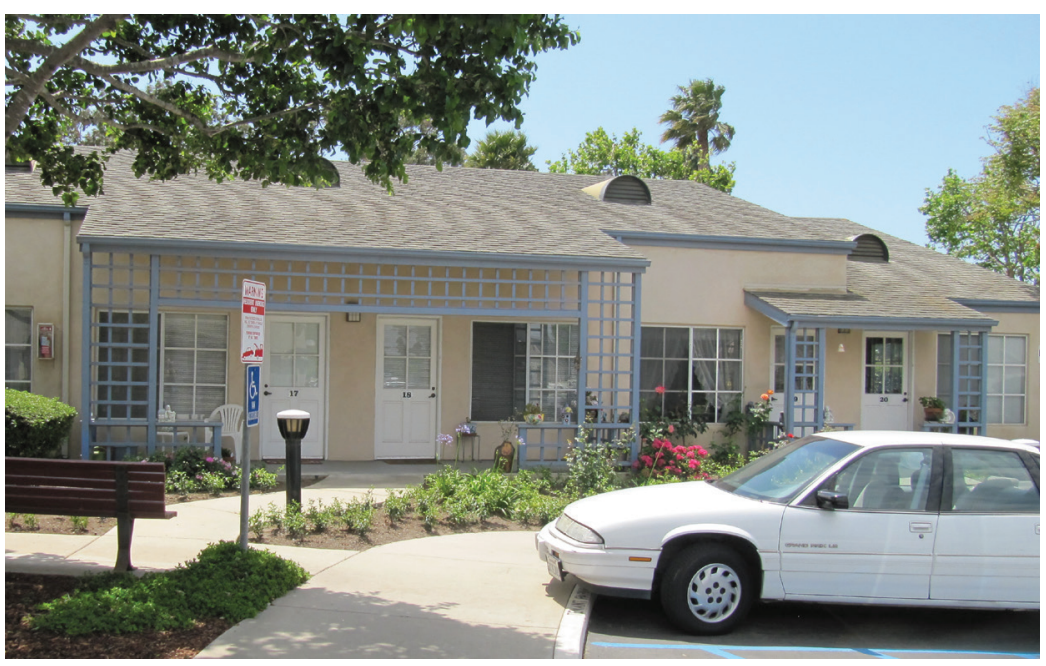

- Income and age-restricted units: Age 62 and over

- Rent is 30\% of resident's income

- An average rent has been presented here based on $30 \%$ of the low income category $(<50 \%$ AMI)

- 14 persons on wait list for Valentine Court I and II (typically $12-15$ is a year wait)

\begin{tabular}{|l|c|l|l|l|l|}
\hline BR/BA & \# UNITS & BASE RENT & SQ. FOOTAGE & RENT/S.F. & VACANT \\
\hline STUDI0-1 BA & 8 & $\$ 350$ & 415 & $\$ 0.84$ & 0 \\
\hline 1 BR-1 BA & 26 & $\$ 350$ & 540 & $\$ 0.65$ & 0 \\
\hline
\end{tabular}

\begin{tabular}{|l|l|l|l|l|l|l|l|l|l|}
\hline \multicolumn{4}{|c|}{ UNIT AMENITIES } & \multicolumn{4}{c|}{ PROJECT AMENITIES } & \multicolumn{2}{c|}{ TENANT PAYS } \\
\hline Central Heat & X & Refrigerator & X & Community Room & X & Business Center & & Electricity & X \\
\hline Central AC & & Stove/Oven & X & Swimming Pool & & Car Wash Area & & Heat (G or E) & E \\
\hline Blinds & X & Dishwasher & & Spa/Jacuzzi & & Gated Security & & Hot Water & E \\
\hline Carpet & X & Garbage Disposal & X & Exercise Room & & Security Patrol & & Cooking (G or E) & E \\
\hline Ceiling Fan & & Microwave & & Picnic Area & X & Security Camera & X & TV (C or S) & C \\
\hline Skylight & & Washer/Dryer & & Playground & & & & Water & \\
\hline Storage Closet & X & W/D Hook-ups & & Tennis Court & & & & Sewer & \\
\hline Coat Closet & X & Surface Parking & X & Basketball Court & & & & Trash & \\
\hline Walk-In Closet & & Carport & & Volleyball Court & & & & & \\
\hline Fireplace & & Underground Parking & & On-site Manager & X & & & & \\
\hline Patio & & Garage & & Laundry Room & X & & & & \\
\hline Balcony & & Parking Garage & & Computer Room & & & & & \\
\hline
\end{tabular}




\section{E. COMPETITIVE RENTAL MARKET}

5. \begin{tabular}{|l|l|l|l|}
\hline NAME & Valentine Court II & DATE & May 8, 2013 \\
\hline ADDRESS & 1760 S McClelland St. & TOTAL UNITS & 18 \\
\hline CITY & Santa Maria & CONDITION & Good \\
\hline MANAGER & Chris Morrison & YEAR BUILT & 1999 \\
\hline TELEPHONE & $805-925-6373$ & BLDG. STYLE & two-story \\
\hline
\end{tabular}

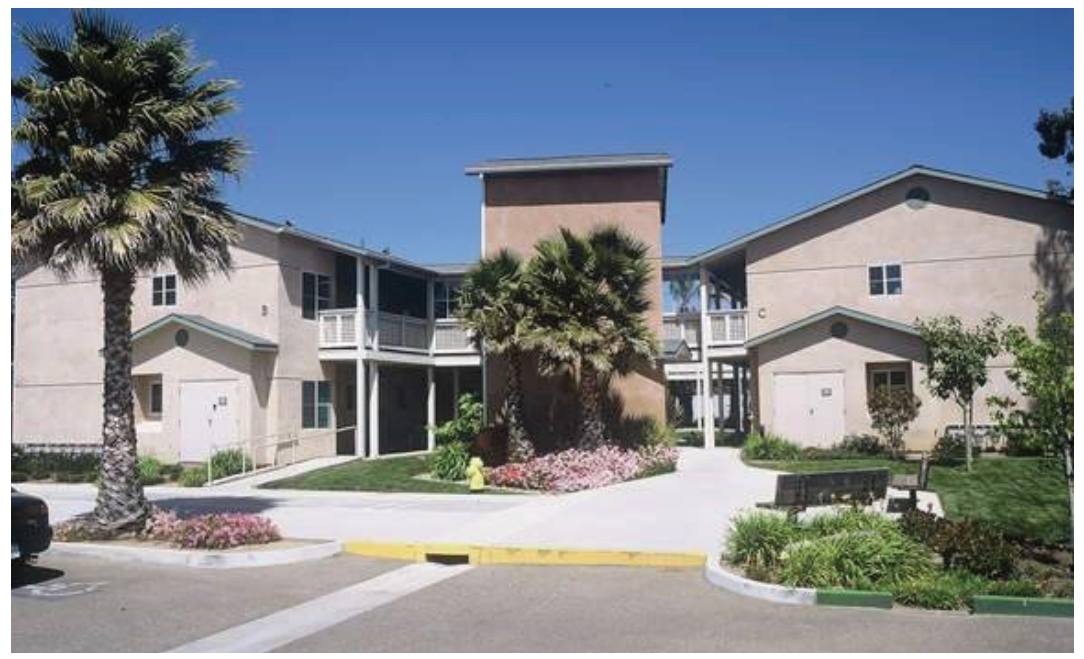

- Income and age-restricted units: Age 62 and over

- Rent is $30 \%$ of resident's income

- An average rent has been presented here based on $30 \%$ of the low income category $(<50 \%$ AMI)

- 14 persons on wait list for Valentine Court I and II (typically $12-15$ is a year wait)

\begin{tabular}{|l|c|l|l|l|l|}
\hline BR/BA & \# UNITS & BASE RENT & SQ. FOOTAGE & RENT/S.F. & VACANT \\
\hline 1 BR-1 BA & 18 & $\$ 350$ & 600 & $\$ 0.58$ & 0 \\
\hline
\end{tabular}

\begin{tabular}{|l|l|l|l|l|l|l|l|l|l|}
\hline \multicolumn{3}{|c|}{ UNIT AMENITIES } & \multicolumn{4}{c|}{ PROJECT AMENITIES } & \multicolumn{2}{c|}{ TENANT PAYS } \\
\hline Central Heat & X & Refrigerator & X & Community Room & X & Business Center & & Electricity & X \\
\hline Central AC & & Stove/Oven & X & Swimming Pool & & Car Wash Area & & Heat (G or E) & E \\
\hline Blinds & X & Dishwasher & & Spa/Jacuzzi & & Gated Security & & Hot Water & E \\
\hline Carpet & X & Garbage Disposal & X & Exercise Room & & Security Patrol & & Cooking (G or E) & E \\
\hline Ceiling Fan & & Microwave & & Picnic Area & X & Security Camera & X & TV (C or S) & C \\
\hline Skylight & & Washer/Dryer & & Playground & & & & Water & \\
\hline Storage Closet & X & W/D Hook-ups & & Tennis Court & & & & Sewer & \\
\hline Coat Closet & X & Surface Parking & X & Basketball Court & & & & Trash & \\
\hline Walk-In Closet & & Carport & & Volleyball Court & & & & & \\
\hline Fireplace & & Underground Parking & & On-site Manager & X & & & & \\
\hline Patio & & Garage & & Laundry Room & X & & & & \\
\hline Balcony & & Parking Garage & & Computer Room & & & & & \\
\hline
\end{tabular}




\section{E. COMPETITIVE RENTAL MARKET}

6.

\begin{tabular}{|l|l|l|l|}
\hline NAME & Oak Knolls Haven & DATE & May 8, 2013 \\
\hline ADDRESS & 4845 S. Bradley Rd. & TOTAL UNITS & 40 \\
\hline CITY & Orcutt & CONDITION & Good \\
\hline MANAGER & Celia Reyes & YEAR BUILT & 1983 \\
\hline TELEPHONE & $805-934-2027$ & BLDG. STYLE & two-story \\
\hline
\end{tabular}

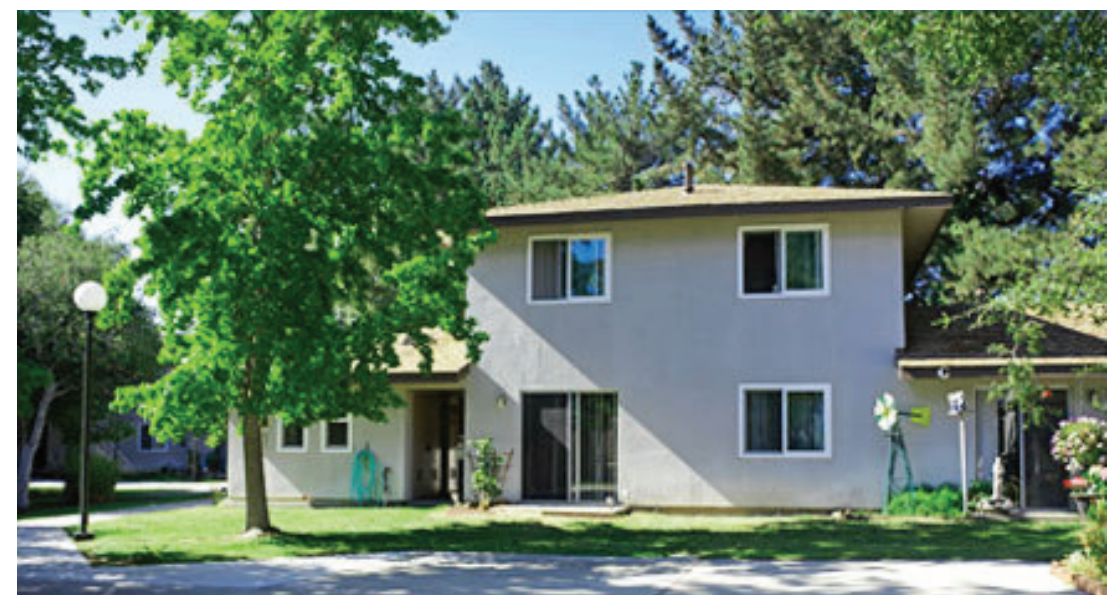

- Located south of city limits in Orcutt

- HUD Section 202 property

- Income and Age Restricted$>62$ and $<50 \%$ AMI

- 6 miles away from subject property

\begin{tabular}{|l|c|l|l|l|l|}
\hline BR/BA & \# UNITS & BASE RENT & SQ. FOOTAGE & RENT/S.F. & VACANT \\
\hline 1 BR-1 BA & 40 & $\$ 650$ & 450 & $\$ 1.44$ & 0 \\
\hline
\end{tabular}

\begin{tabular}{|l|l|l|l|l|l|l|l|l|l|}
\hline \multicolumn{3}{|c|}{ UNIT AMENITIES } & \multicolumn{4}{c|}{ PROJECT AMENITIES } & \multicolumn{2}{c|}{ TENANT PAYS } \\
\hline Central Heat & X & Refrigerator & X & Community Room & X & Business Center & & Electricity & X \\
\hline Central AC & X & Stove/Oven & X & Swimming Pool & & Car Wash Area & & Heat (G or E) & E \\
\hline Blinds & X & Dishwasher & X & Spa/Jacuzzi & & Gated Security & & Hot Water & E \\
\hline Carpet & X & Garbage Disposal & X & Exercise Room & & Security Patrol & & Cooking (G or E) & E \\
\hline Ceiling Fan & X & Microwave & & Picnic Area & X & Security Camera & & TV (C or S) & C \\
\hline Skylight & & Washer/Dryer & & Playground & & & & Water & \\
\hline Storage Closet & X & W/D Hook-ups & & Tennis Court & & & & Sewer & \\
\hline Coat Closet & & Surface Parking & X & Basketball Court & & & & Trash & \\
\hline Walk-In Closet & & Carport & & Volleyball Court & & & & & \\
\hline Fireplace & & Underground Parking & & On-site Manager & X & & & & \\
\hline Patio & & Garage & & Laundry Room & X & & & & \\
\hline Balcony & & Parking Garage & & Computer Room & X & & & & \\
\hline
\end{tabular}




\section{E. COMPETITIVE RENTAL MARKET}

\begin{tabular}{|l|l|l|l|}
\hline NAME & Santa Maria Terrace Living & DATE & May 8,2013 \\
\hline ADDRESS & 1405 E. Main Street & TOTAL UNITS & 40 (unassisted) \\
\hline CITY & Santa Maria & CONDITION & Good \\
\hline MANAGER & Crystal Lawrence & YEAR BUILT & 1978 \\
\hline TELEPHONE & $805-925-8713$ & BLDG. STYLE & four-story \\
\hline
\end{tabular}

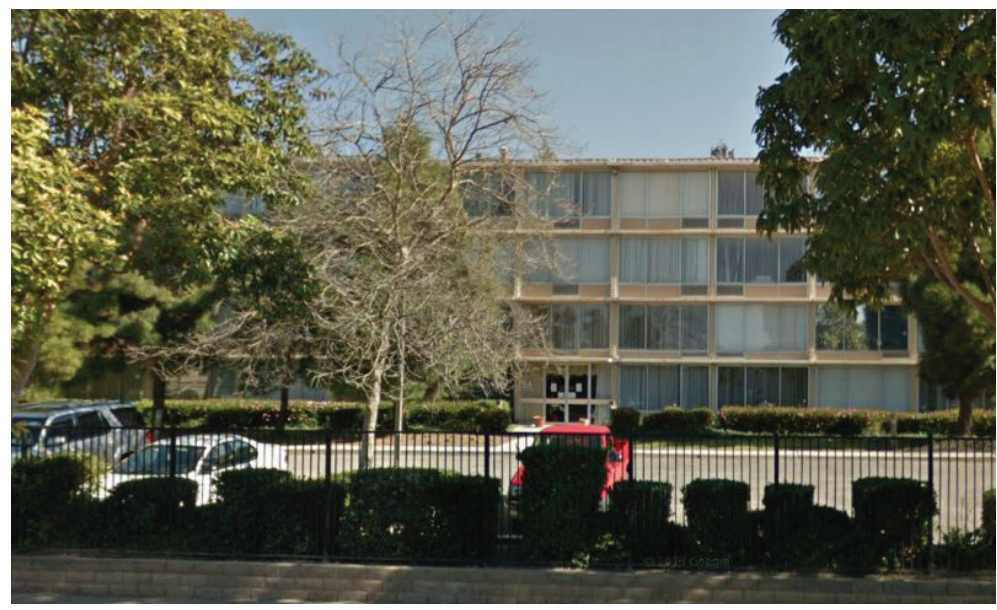

- Former hotel built in 1978, and operated as market-rate independent and assisted senior housing since 2000

- Offers a high number of services to residents including all meals, shuttle rides to appointments, and weekly activities

- The number of units listed reflects the approximate number of independent living units; all others are assisted.

\begin{tabular}{|l|c|l|l|l|l|}
\hline BR/BA & \# UNITS & RENT & SQ. FO0TAGE & RENT/S.F. & VACANT \\
\hline STUDI0-1 BA & 40 & $\$ 2,400$ & 282 & $\$ 8.51$ & $60 \%$ (total) \\
\hline
\end{tabular}

\begin{tabular}{|l|l|l|l|l|l|l|l|l|l|}
\hline \multicolumn{3}{|c|}{ UNIT AMENITIES } & \multicolumn{4}{c|}{ PROJECT AMENITIES } & \multicolumn{2}{c|}{ TENANT PAYS } \\
\hline Central Heat & X & Refrigerator & & Community Room & X & Business Center & & Electricity & \\
\hline Central AC & X & Stove/Oven & & Swimming Pool & & Car Wash Area & & Heat (G or E) & \\
\hline Blinds & X & Dishwasher & & Spa/Jacuzzi & & Gated Security & & Hot Water & \\
\hline Carpet & X & Garbage Disposal & & Exercise Room & & Security Patrol & & Cooking (G or E) & \\
\hline Ceiling Fan & & Microwave & & Picnic Area & & Security Camera & & TV (C or S) & \\
\hline Skylight & & Washer/Dryer & & Playground & & & & Water & \\
\hline Storage Closet & X & W/D Hook-ups & & Tennis Court & & & & Sewer & \\
\hline Coat Closet & & Surface Parking & X & Basketball Court & & & & Trash & \\
\hline Walk-In Closet & & Carport & X & Volleyball Court & & & & & \\
\hline Fireplace & & Underground Parking & & On-site Manager & X & & & & \\
\hline Patio & & Garage & & Laundry Room & X & & & & \\
\hline Balcony & X & Parking Garage & & Computer Room & & & & & \\
\hline
\end{tabular}




\section{E. COMPETITIVE RENTAL MARKET}

\begin{tabular}{|c|c|c|c|}
\hline NAME & Hummel Village & DATE & May 8, 2013 \\
\hline ADDRESS & 4468 Hummel Dr. Ste 101 & TOTAL UNITS & 32 \\
\hline CITY & Orcutt & CONDITION & Good \\
\hline MANAGER & Ginny Blough & YEAR BUILT & 2004 \\
\hline TELEPHONE & $805-937-6204$ & BLDG. STYLE & one-story cottage \\
\hline
\end{tabular}

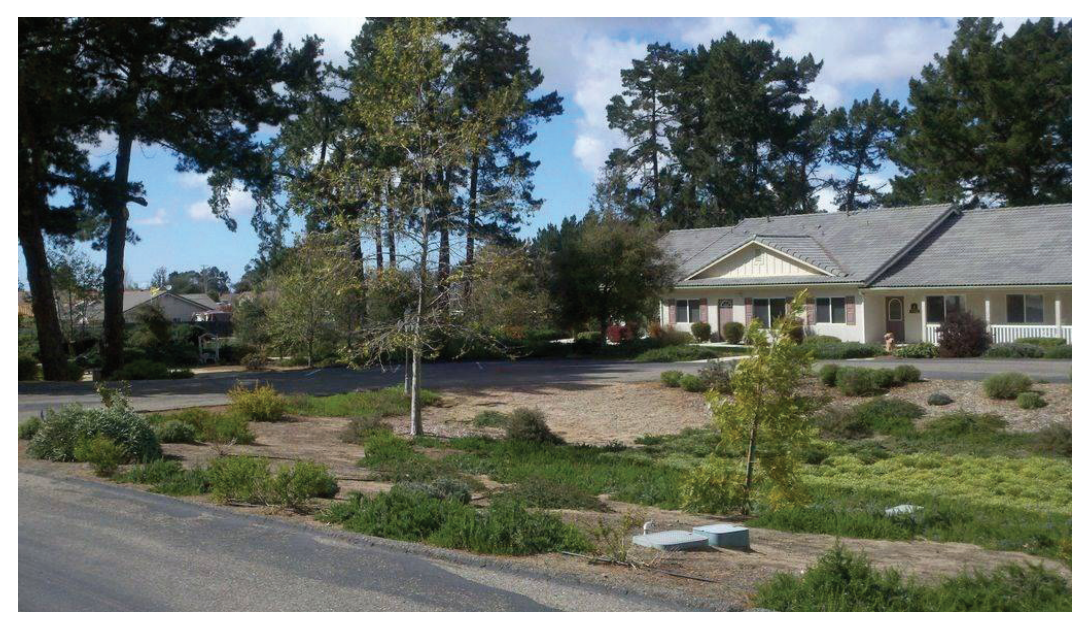

- Age restricted: $>55$

- Rent includes all utilities, weekly housekeeping, weekly activities, and cable and internet

- Six guest rooms provided for over-night guests

- Waiting list for studios

\begin{tabular}{|l|c|l|l|l|l|}
\hline BR/BA & \# UNITS & RENT & SQ. F0OTAGE & RENT/S.F. & VACANT \\
\hline STUDI0- 1 BA & 4 & $\$ 1000$ & 475 & $\$ 2.11$ & 0 \\
\hline 2 BR-1 or 2 BA & 28 & $\$ 1725$ & $700-900$ & $\$ 1.92-\$ 2.46$ & 6 \\
\hline
\end{tabular}

\begin{tabular}{|l|l|l|l|l|l|l|l|l|l|}
\hline \multicolumn{3}{|c|}{ UNIT AMENITIES } & \multicolumn{4}{c|}{ PROJECT AMENITIES } & \multicolumn{2}{c|}{ TENANT PAYS } \\
\hline Central Heat & X & Refrigerator & X & Community Room & X & Business Center & & Electricity & \\
\hline Central AC & & Stove/Oven & X & Swimming Pool & & Car Wash Area & & Heat (G or E) & \\
\hline Blinds & X & Dishwasher & X & Spa/Jacuzzi & & Gated Security & X & Hot Water & \\
\hline Carpet & X & Garbage Disposal & & Exercise Room & & Security Patrol & & Cooking (G or E) & \\
\hline Ceiling Fan & & Microwave & X & Picnic Area & X & Security Camera & & TV (C or S) & \\
\hline Skylight & & Washer/Dryer & X & Playground & & & & Water & \\
\hline Storage Closet & X & W/D Hook-ups & & Tennis Court & & & & Sewer & \\
\hline Coat Closet & & Surface Parking & X & Basketball Court & & & & Trash & \\
\hline Walk-In Closet & & Carport & & Volleyball Court & & & & & \\
\hline Fireplace & & Underground Parking & & On-site Manager & X & & & & \\
\hline Patio & X & Garage & X & Laundry Room & & & & & \\
\hline Balcony & & Parking Garage & & Computer Room & X & & & & \\
\hline
\end{tabular}




\section{E. COMPETITIVE RENTAL MARKET}

\begin{tabular}{|c|c|c|c|}
\hline NAME & Merril Gardens & DATE & May 8, 2013 \\
\hline ADDRESS & 1220 Suey Road & TOTAL UNITS & 33 cottages \\
\hline CITY & Santa Maria & CONDITION & Good \\
\hline MANAGER & Kim Adams & YEAR BUILT & 2000 \\
\hline TELEPHONE & 805-310-4102 & BLDG. STYLE & one-story \\
\hline
\end{tabular}

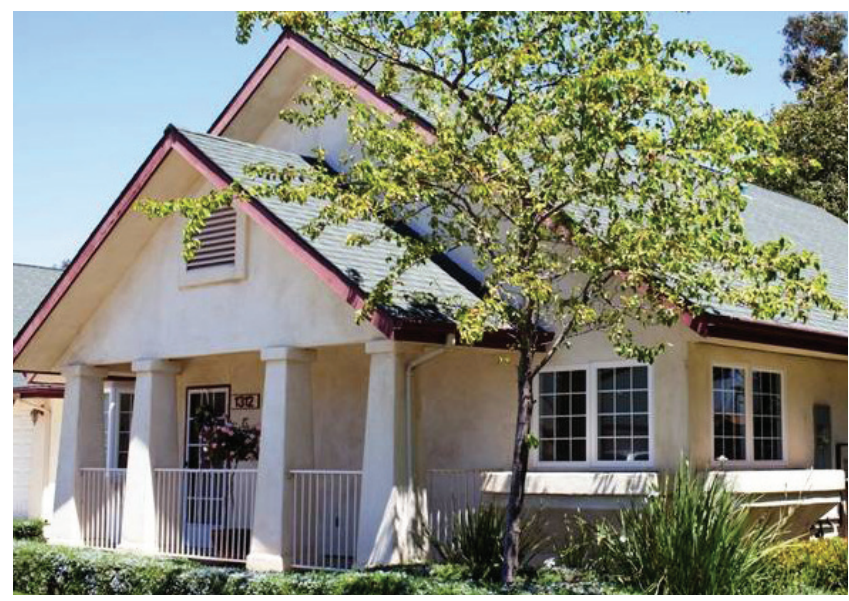

- The 33 cottages are 2 BR-2BA duplexes with a shared garage and laundry.

- The property also houses 182 assisted living units

- All utilities are included in rent except for telephone. Rent also includes one meal a day at the development's dining hall.

\begin{tabular}{|l|c|l|l|l|l|}
\hline BR/BA & \# UNITS & RENT & SQ. FOOTAGE & RENT/S.F. & VACANT \\
\hline 2 BR-2 BA & 33 & $\$ 3200$ & 1200 & $\$ 2.67$ & 0 \\
\hline
\end{tabular}

\begin{tabular}{|l|l|l|l|l|l|l|l|l|l|}
\hline \multicolumn{3}{|c|}{ UNIT AMENITIES } & \multicolumn{4}{c|}{ PROJECT AMENITIES } & \multicolumn{2}{c|}{ TENANT PAYS } \\
\hline Central Heat & X & Refrigerator & X & Community Room & X & Business Center & & Electricity & \\
\hline Central AC & X & Stove/Oven & X & Swimming Pool & X & Car Wash Area & & Heat (G or E) & \\
\hline Blinds & X & Dishwasher & X & Spa/Jacuzzi & X & Gated Security & X & Hot Water & \\
\hline Carpet & X & Garbage Disposal & & Exercise Room & & Security Patrol & & Cooking (G or E) & \\
\hline Ceiling Fan & & Microwave & X & Picnic Area & X & Security Camera & & TV (C or S) & \\
\hline Skylight & & Washer/Dryer & X & Playground & & & & Water & \\
\hline Storage Closet & X & W/D Hook-ups & & Tennis Court & & & & Sewer & \\
\hline Coat Closet & X & Surface Parking & X & Basketball Court & & & & Trash & \\
\hline Walk-In Closet & & Carport & & Volleyball Court & & & & & \\
\hline Fireplace & & Underground Parking & & On-site Manager & X & & & & \\
\hline Patio & X & Garage & X & Laundry Room & X & & & & \\
\hline Balcony & & Parking Garage & & Computer Room & & & & & \\
\hline
\end{tabular}




\section{E. COMPETITIVE RENTAL MARKET}

\section{MAP OF LOCATION OF RENT COMPARABLES AND PROXIMITY TO SITE}

There are three low-income senior housing developments within one mile of the proposed site. Two more lowincome developments and one market-rate development are located within two miles of the site. The two housing developments shown several miles south of the site are in the CDP, Orcutt. They are Oak Knolls Haven, Section 202 housing, and Hummel Village, a market-rate cottage-style development.

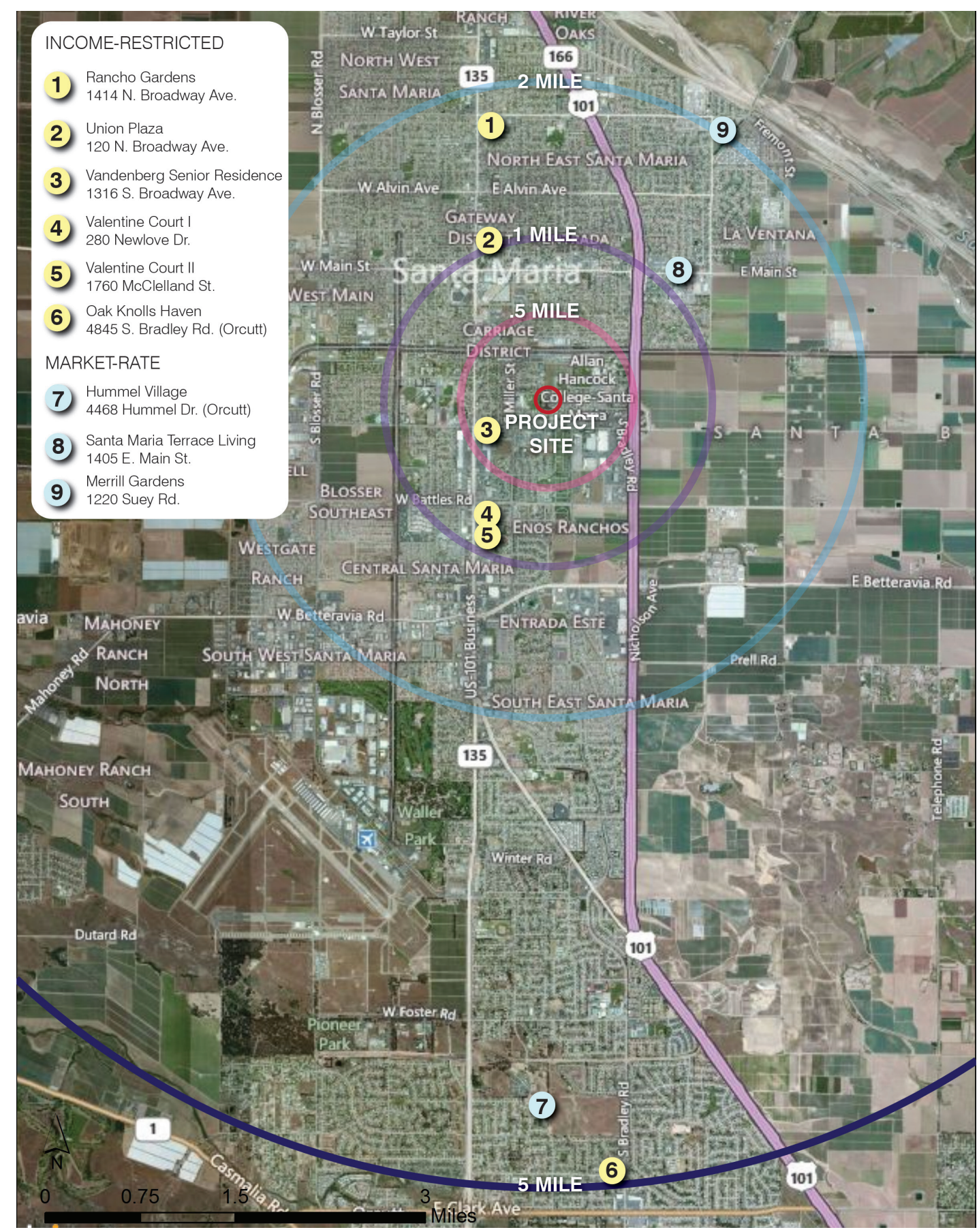

Figure 8. Existing senior housing developments

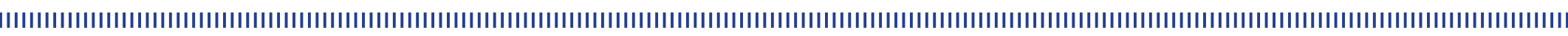




\section{E. COMPETITIVE RENTAL MARKET}

\section{MAP OF PENDING SANTA MARIA SENIOR HOUSING DEVELOPMENT PROJECTS}

Santa Maria Senior Village has been proposed at 450/460 W. Stowell Road, shown below with the number one. The developers of the project received approval of a Planned Development Overlay in 2008 for a sixty-unit market-rate project for seniors 55+. Santa Maria City Staff indicated the developer has received time extensions for the project and is waiting for the market to recover before proceeding with the development. Pending site two was originally approved as a 21 -unit $55+$ senior project in 2006. The property changed hands and the new owner is now working to convert the project from senior to all-ages due to the developer's market research that a $65+$ project would not succeed. Site number three is a mixed-use project called the Lakeview Promenade, a lifestyle center. The mixeduse center would include 78 senior market-rate units. The developer is currently requesting a time extension from the City to extend the project's approvals. These units were not added as "pending units" to the demand estimate calculation because the proposed units are market-rate, not income-restricted.

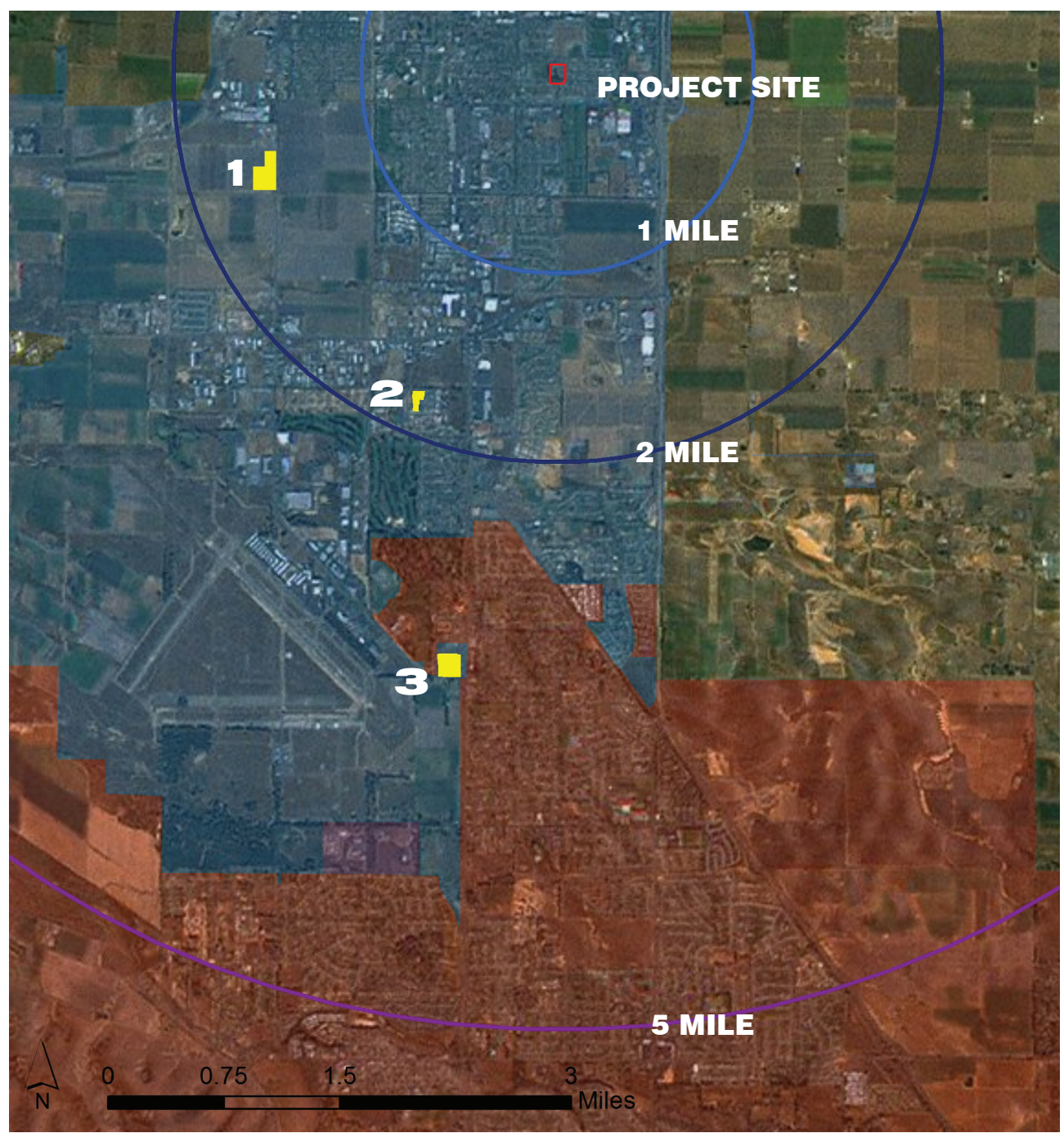

Figure 9. Pending senior housing developments 


\section{E. COMPETITIVE RENTAL MARKET}

Table 20. Rent Matrix of Low-Income Senior Units in Market Area

\begin{tabular}{|c|c|c|c|c|c|c|c|c|}
\hline \multicolumn{9}{|c|}{ RENT MATRIX OF LOW-INCOME COMPARABLE SITES } \\
\hline Subject Property & Bethel Street & Valentine Court I & $\begin{array}{l}\text { Valentine } \\
\text { Court II }\end{array}$ & $\begin{array}{l}\text { Vandenberg Senior } \\
\text { Residence }\end{array}$ & Union Plaza & $\begin{array}{l}\text { Oak Knolls } \\
\text { Haven Apts. }\end{array}$ & Rancho Gardens & \\
\hline Date of Market Study: & $\begin{array}{l}624 \text { E Camino } \\
\text { Colegio }\end{array}$ & $\begin{array}{l}280 \text { Newlove } \\
\text { Drive }\end{array}$ & $\begin{array}{l}1760 \mathrm{~S} . \\
\text { McClelland }\end{array}$ & 1316 S. Broadway & $\begin{array}{l}120 \mathrm{~N} . \\
\text { Broadway }\end{array}$ & $\begin{array}{l}4845 \mathrm{~S} . \\
\text { Bradley Rd. }\end{array}$ & $\begin{array}{l}1414 \mathrm{~N} . \\
\text { Broadway }\end{array}$ & \\
\hline 1-Jun-13 & Santa Maria & Santa Maria & Santa Maria & Santa Maria & Santa Maria & Orcutt & Santa Maria & \\
\hline \multirow[t]{3}{*}{$\begin{array}{l}\text { Prepared By: } \\
\text { Liz Brighton, MCRP }\end{array}$} & & $805-925-6373$ & $805-925-6373$ & $805-922-6631$ & $\begin{array}{l}805-922- \\
5226\end{array}$ & $\begin{array}{l}805-934- \\
2027\end{array}$ & $805-349-8722$ & \\
\hline & $\begin{array}{l}\text { Use Subject's } \\
\text { Highest Rent }\end{array}$ & & & & & & & $\begin{array}{l}\text { Totals \& Weighted } \\
\text { Averages }\end{array}$ \\
\hline & Characteristic & Char & Char & Char & Char & Char & Char & \\
\hline (“M”arket, “L”ow Income) & L & L & $\mathrm{L}$ & L & L & L & L & \\
\hline Distance in Miles from Subject & & 1.10 & 0.40 & 0.80 & 1.40 & 6.00 & 2.20 & \\
\hline Number of Units & & 26 & 18 & 120 & 121 & 40 & 118 & 444 \\
\hline Vacancy Rate & & $0 \%$ & $0 \%$ & $0 \%$ & $0 \%$ & $6 \%$ & $0 \%$ & \\
\hline Waiting List ("Y"es or "N"0) & & Y & Y & Y & Y & Y & $\mathrm{N}$ & \\
\hline Turnover Rate & & $10 \%$ & $10 \%$ & $10 \%$ & $10 \%$ & $10 \%$ & $10 \%$ & \\
\hline Unit Size in SF & 575 & 540 & 600 & 350 & 550 & 450 & 320 & 427.25225 \\
\hline Aggregate Size in SF & & 14040 & 10800 & 42000 & 67100 & 18000 & 37760 & 189,700 \\
\hline Base Rent & $\$ 896$ & $\$ 400$ & $\$ 350$ & $\$ 575$ & $\$ 250$ & $\$ 650$ & $\$ 675$ & $\$ 502$ \\
\hline Aggregate Rent & & $\$ 10,400$ & $\$ 7,200$ & $\$ 69,000$ & $\$ 30,500$ & $\$ 26,000$ & $\$ 79,650$ & $\$ 222,750$ \\
\hline Value Ratio (\$/SF) & $\$ 1.56$ & $\$ 0.74$ & $\$ 0.67$ & $\$ 1.64$ & $\$ 0.45$ & $\$ 1.44$ & $\$ 2.11$ & $\$ 1.17$ \\
\hline \# of stories & 1 & 1 & 2 & 3 & 7 & 1 & 1 & \\
\hline Elevator ("Y"es or "N"0) & $\mathrm{N}$ & $\mathrm{N}$ & Y & Y & Y & $\mathrm{N}$ & $\mathrm{N}$ & \\
\hline \# of Bedrooms & 1 & 1 & 1 & 1 & 1 & 1 & 1 & \\
\hline \# of Bathrooms & 1 & 1 & 1 & 1 & 1 & 1 & 1 & \\
\hline \multicolumn{9}{|l|}{ Unit Size Adjustment } \\
\hline \multicolumn{9}{|l|}{ Rent Concessions } \\
\hline Age (built or renovated) & & 1990 & 1999 & mid 90's-ren. & 1975 & 1983 & 2000-ren. & \\
\hline \multicolumn{9}{|l|}{ Utilities Paid by Tenant } \\
\hline Electricity & $x$ & $x$ & $x$ & $x$ & $x$ & $x$ & $x$ & \\
\hline Heat ("G"as or "E"lectric) & $\mathrm{e}$ & e & e & e & e & $\mathrm{e}$ & e & \\
\hline Hot Water (G or E) & e & e & e & e & e & e & e & \\
\hline Cooking (G or E) & e & e & e & e & e & e & e & \\
\hline TV ("C"able or "S"atellite) & c & c & c & c & c & c & c & \\
\hline \multicolumn{9}{|l|}{ Water } \\
\hline \multicolumn{9}{|l|}{ Sewer } \\
\hline \multicolumn{9}{|l|}{ Trash } \\
\hline \multicolumn{9}{|l|}{ Unit Amenities } \\
\hline Central Heat/Cool & $\mathrm{H}$ & $\mathrm{H}$ & $\mathrm{H}$ & $x$ & $\mathrm{H}$ & $x$ & $x$ & \\
\hline Blinds & $x$ & $x$ & $x$ & $x$ & $x$ & $x$ & $x$ & \\
\hline Carpet & $x$ & $x$ & $x$ & $x$ & $x$ & $x$ & $x$ & \\
\hline \multicolumn{9}{|l|}{ Ceiling Fan } \\
\hline Skylight & & & & & & & & \\
\hline
\end{tabular}




\section{E. COMPETITIVE RENTAL MARKET}

\begin{tabular}{|l|l|l|l|l|l|l|l|l|}
\hline Storage Closet & & & & $x$ & $x$ & $x$ & $x$ & \\
\hline Coat Closet & $\mathrm{x}$ & $\mathrm{x}$ & $\mathrm{x}$ & & & $\mathrm{x}$ & & \\
\hline Walk-In Closet & & & & & & & & \\
\hline Fireplace & & & & & & & & \\
\hline Patio/Balcony & & & & $15 / 120$ & $x$ & & $x$ & \\
\hline Appliances & & & & & & & & \\
\hline Refrigerator & $\mathrm{x}$ & $\mathrm{x}$ & $\mathrm{x}$ & $\mathrm{x}$ & $\mathrm{x}$ & $\mathrm{x}$ & $\mathrm{x}$ & \\
\hline Stove/Oven & $\mathrm{x}$ & $\mathrm{x}$ & $\mathrm{x}$ & $\mathrm{x}$ & $\mathrm{x}$ & $\mathrm{x}$ & $\mathrm{x}$ & \\
\hline Dishwasher & & & & & & & & \\
\hline
\end{tabular}

\begin{tabular}{|c|c|c|c|c|c|c|c|c|c|}
\hline Garbage Disposal & $x$ & $x$ & $x$ & $x$ & $x$ & $x$ & & & \\
\hline Microwave & & & & $x$ & & & $x$ & & \\
\hline \multicolumn{10}{|l|}{ Washer/Dryer } \\
\hline \multicolumn{10}{|l|}{ Washer/Dryer Hook-ups } \\
\hline \multicolumn{10}{|l|}{ Parking/Transportation } \\
\hline Surface Parking & $x$ & $x$ & $x$ & $x$ & $x$ & $x$ & $x$ & & \\
\hline Carport & & & & $x$ & & & & & \\
\hline \multicolumn{10}{|l|}{ Underground Parking } \\
\hline \multicolumn{10}{|l|}{ Detached Garage } \\
\hline Attached Garage & & & & & & $x$ & & & \\
\hline \multicolumn{10}{|l|}{ Tuck-under Garage } \\
\hline \multicolumn{10}{|l|}{ Parking Garage } \\
\hline \multicolumn{10}{|l|}{ Project Amenities } \\
\hline Community Room & $x$ & $x$ & $x$ & $x$ & $x$ & $x$ & $x$ & & \\
\hline Swimming Pool & & & & $x$ & & & & & \\
\hline Spa/Jacuzzi & & & & $x$ & & & & & \\
\hline Exercise Room & & & & $x$ & & & & & \\
\hline Picnic Area & $x$ & $x$ & $x$ & . & $x$ & $x$ & $x$ & & \\
\hline \multicolumn{10}{|l|}{ Tot Lot/Playground } \\
\hline \multicolumn{10}{|l|}{ Tennis Court } \\
\hline \multicolumn{10}{|l|}{ Basketball Court } \\
\hline \multicolumn{10}{|l|}{ Volleyball Court } \\
\hline On Site Manager & $x$ & $x$ & $x$ & $x$ & $x$ & $x$ & $x$ & & \\
\hline Laundry Room & $x$ & $x$ & $x$ & $x$ & $x$ & $x$ & $x$ & & \\
\hline \multicolumn{10}{|l|}{ Computer Room } \\
\hline \multicolumn{10}{|l|}{ Business Center } \\
\hline \multicolumn{10}{|l|}{ Car Wash Area } \\
\hline \multicolumn{10}{|l|}{ Security } \\
\hline Gated & & & & & & $x$ & & & \\
\hline \multicolumn{10}{|l|}{ Courtesy Patrol } \\
\hline Surveillance Camera & & $x$ & $x$ & & & & & Avgs. & Differential \\
\hline Adjusted Rent & $\$ 896$ & $\$ 400$ & $\$ 400$ & $\$ 575$ & $\$ 250$ & $\$ 650$ & $\$ 675$ & $\$ 502$ & $78.60 \%$ \\
\hline Aggregate Adjusted Rent & & $\$ 10,400$ & $\$ 7,200$ & $\$ 69,000$ & $\$ 32,250$ & $\$ 26,000$ & $\$ 79,650$ & $\$ 222,750$ & \\
\hline Adjusted Value Ratio (\$/SF) & $\$ 1.56$ & $\$ 0.74$ & $\$ 0.67$ & $\$ 1.64$ & $\$ 0.45$ & $\$ 1.44$ & $\$ 2.11$ & $\$ 1.17$ & $32.71 \%$ \\
\hline Adjusted Rent/Base Rent & & $100 \%$ & $100 \%$ & $100 \%$ & $100 \%$ & $100 \%$ & $100 \%$ & & \\
\hline
\end{tabular}




\section{E. COMPETITIVE RENTAL MARKET}

Table 21. Rent Matrix of Market-Rate Senior Units in Market Area

\begin{tabular}{|c|c|c|c|c|c|c|}
\hline & Bethel Street & Merrill Gardens & Santa Maria Terrace & Hummel Village & & \\
\hline Date of Market Study: & 624 E. Colegio Camino & 1220 Suey Road & 1405 E. Main St. & 4468 Hummel Drive & & \\
\hline (Date) & Santa Maria & Santa Maria & Santa Maria & Orcutt, CDP & & \\
\hline \multirow{2}{*}{$\begin{array}{l}\text { Prepared By: } \\
\text { Liz Brighton, MCRP }\end{array}$} & \multirow{2}{*}{ Use Subject's Highest Rent } & 805-310-4102 & $805-925-8713$ & $805-937-2021$ & & \\
\hline & & & & & & \\
\hline (“M”arket, "L"ow Income) & L & M & M & M & $\begin{array}{l}\text { Totals \& Weighted } \\
\text { Averages }\end{array}$ & Differential \\
\hline Distance in Miles from Subject & & 2.70 & 2.00 & 6.00 & & \\
\hline Number of Units & & 33 & 40 (unassisted) & 32 & 105 & \\
\hline Vacancy Rate & & $0 \%$ & $40 \%$ & $0 \%$ & & \\
\hline Waiting List ("Y"es or "N"0) & & Y & $\mathrm{N}$ & Y & & \\
\hline Turnover Rate & & $0 \%$ & $0 \%$ & $0 \%$ & & \\
\hline Unit Size in SF & 575 & 1200 & 282 & 700 & 697.9047619 & \\
\hline Aggregate Size in SF & & 39600 & 11280 & 22400 & 73,280 & \\
\hline Base Rent & $\$ 896$ & $\$ 3,200$ & $\$ 2,400$ & $\$ 1,500$ & $\$ 2,377$ & $-62.31 \%$ \\
\hline Aggregate Rent & & $\$ 105,600$ & $\$ 96,000$ & $\$ 48,000$ & $\$ 249,600$ & \\
\hline Value Ratio (\$/SF) & $\$ 1.56$ & $\$ 2.67$ & $\$ 8.51$ & $\$ 2.14$ & $\$ 3.41$ & $-54.25 \%$ \\
\hline \# of stories & & 1 & 4 & 1 & & \\
\hline Elevator ("Y"es or "N"0) & & $\mathrm{N}$ & Y & $N$ & & \\
\hline \# of Bedrooms & & 2 & 1 & 1 and 2 & & \\
\hline \# of Bathrooms & & 2 & 1 & 1 & & \\
\hline \multicolumn{7}{|l|}{ Unit Size Adjustment } \\
\hline \multicolumn{7}{|l|}{ Rent Concessions } \\
\hline Age (built or last renovated) & & & 1978-built & 2004 & & \\
\hline Utilities Paid by Tenant & & & $x$ & & & \\
\hline \multicolumn{7}{|l|}{ Electricity } \\
\hline \multicolumn{7}{|l|}{ Heat ("G"as or "E"lectric) } \\
\hline \multicolumn{7}{|l|}{ Hot Water (G or E) } \\
\hline \multicolumn{7}{|l|}{ Cooking (G or E) } \\
\hline \multicolumn{7}{|l|}{ TV ("C"able or "S"atellite) } \\
\hline \multicolumn{7}{|l|}{ Water } \\
\hline \multicolumn{7}{|l|}{ Sewer } \\
\hline \multicolumn{7}{|l|}{ Trash } \\
\hline \multicolumn{7}{|l|}{ Unit Amenities } \\
\hline Central Heat/Cool & & $x$ & $x$ & $\mathrm{H}$ & & \\
\hline Blinds & & $x$ & $x$ & $x$ & & \\
\hline Carpet & & $x$ & $x$ & $x$ & & \\
\hline Ceiling Fan & & & & $x$ & & \\
\hline \multicolumn{7}{|l|}{ Skylight } \\
\hline Storage Closet & & $x$ & $x$ & $x$ & & \\
\hline Coat Closet & & $x$ & & & & \\
\hline \multicolumn{7}{|l|}{ Walk-In Closet } \\
\hline Fireplace & & & & & & \\
\hline
\end{tabular}




\section{E. COMPETITIVE RENTAL MARKET}

\begin{tabular}{|c|c|c|c|c|c|c|}
\hline Patio/Balcony & & & & $x$ & & \\
\hline \multicolumn{7}{|l|}{ Appliances } \\
\hline Refrigerator & & $x$ & & & & \\
\hline Stove/Oven & & $x$ & & $x$ & & \\
\hline Dishwasher & & $x$ & & & & \\
\hline \multicolumn{7}{|l|}{ Garbage Disposal } \\
\hline Microwave & & $x$ & & $x$ & & \\
\hline Washer/Dryer & & $x$ & & & & \\
\hline \multicolumn{7}{|l|}{ Washer/Dryer Hook-ups } \\
\hline \multicolumn{7}{|l|}{ Parking//ransportation } \\
\hline Surface Parking & & $x$ & $\mathrm{x}$ & & & \\
\hline Carport & & & $x$ & & & \\
\hline \multicolumn{7}{|l|}{ Underground Parking } \\
\hline \multicolumn{7}{|l|}{ Detached Garage } \\
\hline Attached Garage & & $x$ & & $x$ & & \\
\hline \multicolumn{7}{|l|}{ Tuck-under Garage } \\
\hline \multicolumn{7}{|l|}{ Parking Garage } \\
\hline \multicolumn{7}{|l|}{ Project Amenities } \\
\hline Community Room & & $x$ & $x$ & $x$ & & \\
\hline Swimming Pool & & $x$ & & & & \\
\hline Spa/Jacuzzi & & $x$ & & & & \\
\hline \multicolumn{7}{|l|}{ Exercise Room } \\
\hline Picnic Area & & $x$ & & $x$ & & \\
\hline \multicolumn{7}{|l|}{ Tot LotPlayground } \\
\hline \multicolumn{7}{|l|}{ Tennis Court } \\
\hline \multicolumn{7}{|l|}{ Basketball Court } \\
\hline \multicolumn{7}{|l|}{ Volleyball Court } \\
\hline On Site Manager & & $x$ & $x$ & $x$ & & \\
\hline Laundry Room & & $x$ & $x$ & $x$ & & \\
\hline Computer Room & & & & $x$ & & \\
\hline \multicolumn{7}{|l|}{ Business Center } \\
\hline \multicolumn{7}{|l|}{ Car Wash Area } \\
\hline \multicolumn{7}{|l|}{ Security } \\
\hline Gated & & $x$ & & $x$ & & \\
\hline \multicolumn{7}{|l|}{ Courtesy Patrol } \\
\hline \multicolumn{7}{|l|}{ Surveillance Camera } \\
\hline Adjusted Rent & $\$ 896$ & $\$ 3,200$ & $\$ 2,400$ & $\$ 1,500$ & $\$ 2,377$ & $-62.31 \%$ \\
\hline Aggregate Adjusted Rent & & $\$ 105,600$ & $\$ 96,000$ & $\$ 48,000$ & $\$ 249,600$ & \\
\hline Adjusted Value Ratio (\$/SF) & $\$ 1.56$ & $\$ 2.67$ & $\$ 8.51$ & $\$ 2.14$ & $\$ 3.41$ & $-54.25 \%$ \\
\hline${ }^{*}$ Adjusted Rent/Base Rent & & $100 \%$ & $100 \%$ & $100 \%$ & & \\
\hline
\end{tabular}


Scheme D - One Story Cottages

With Access Thru Church Parking

\section{Unit Count}

36 (1) Bedroom Units (approx 575 s.f. ea.)

3 (2) Bedroom Units (approx 750 s.f. ea.)

$\overline{39}$ Units Total

Parking Count - 55 spaces

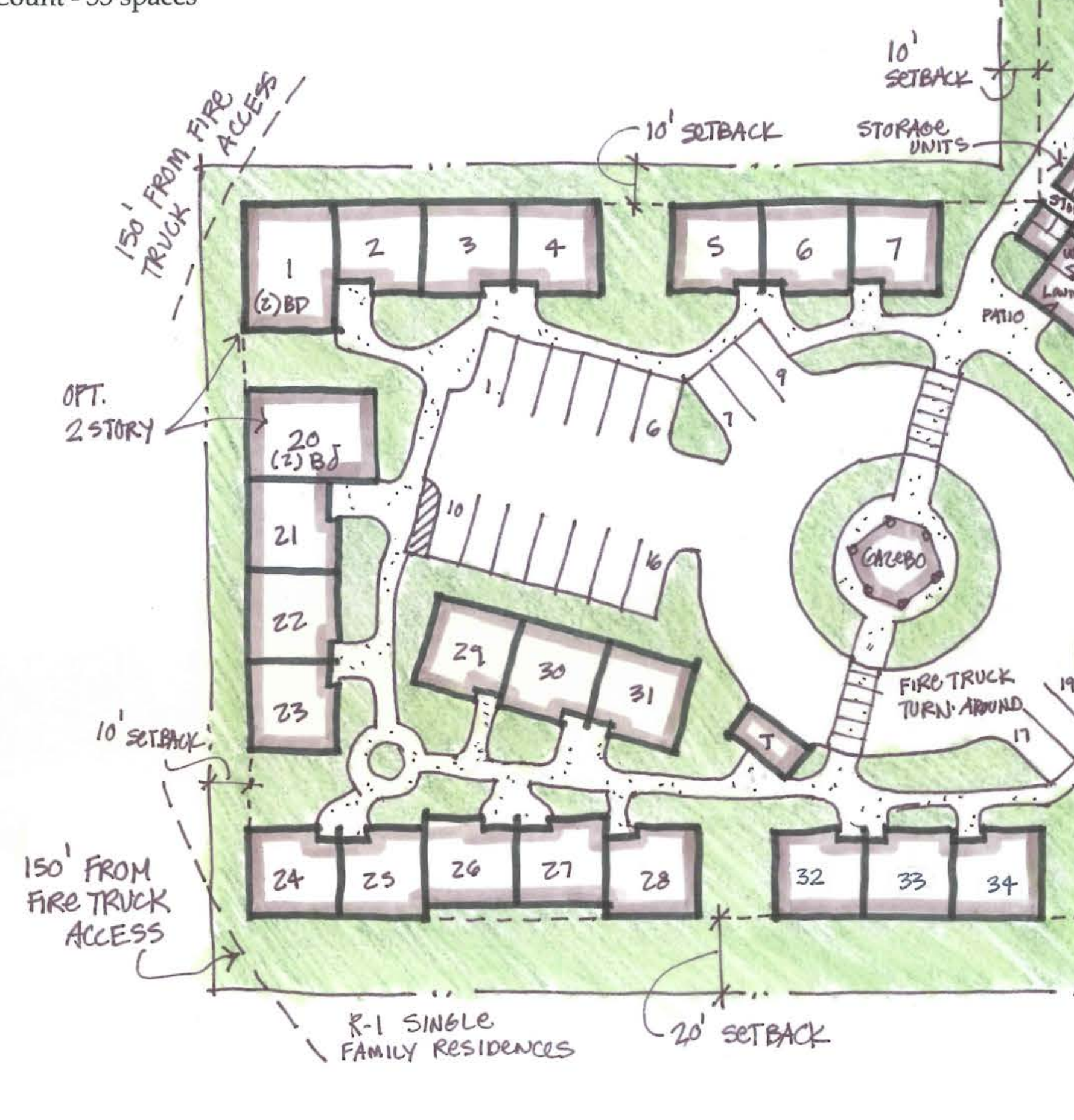

W. Gint:- Great
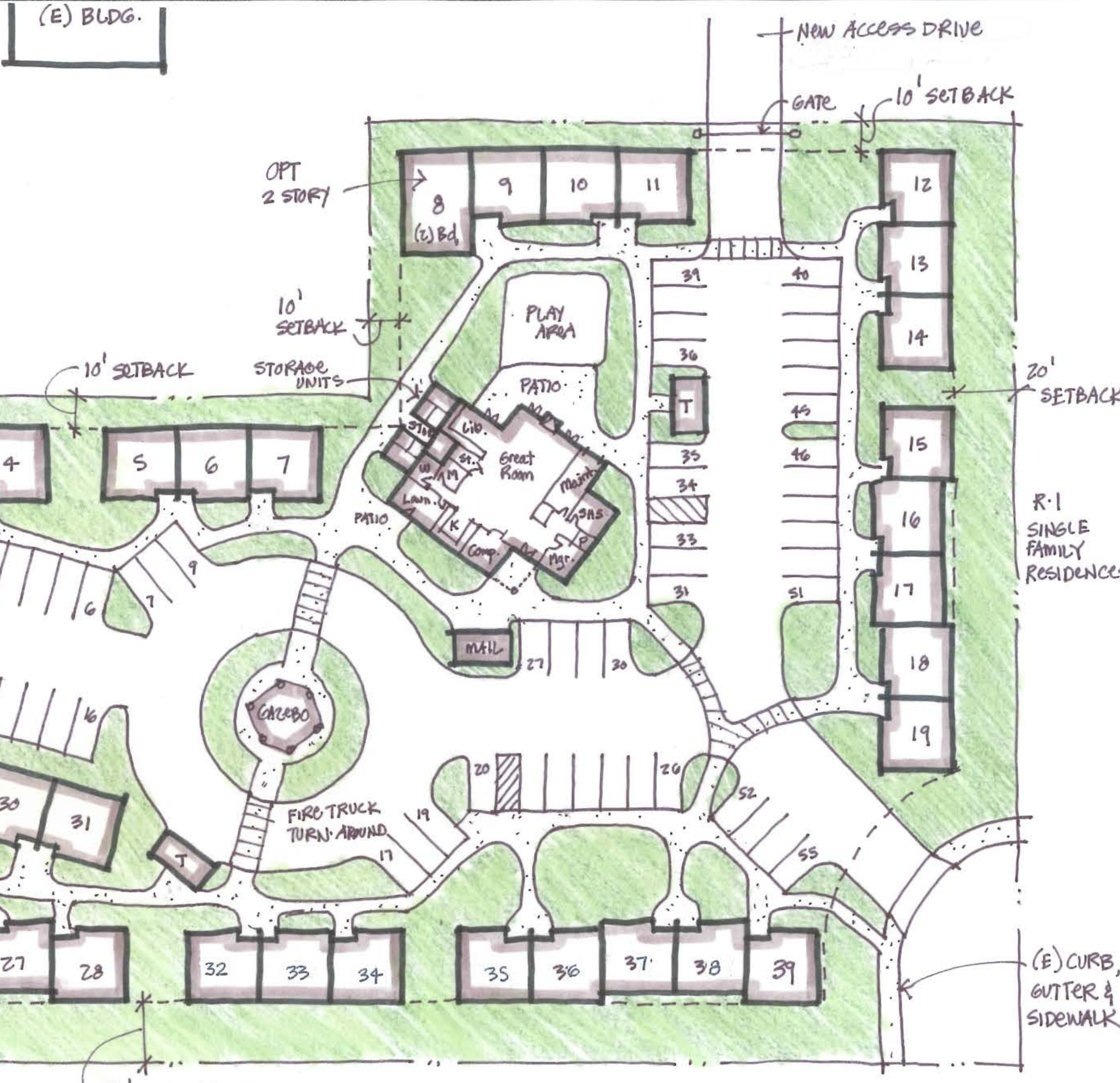

Bethel Street Senior Housing Feasibility People's Self Help Housing 
Scheme E - One Story Cottages

No Access Thru Church Parking

\section{Unit Count}

36 (1) Bedroom Units (approx 575 s.f. ea.)

3 (2) Bedroom Units (approx 750 s.f. ea.)

$\overline{39}$ Units Total

Parking Count - 53 spaces

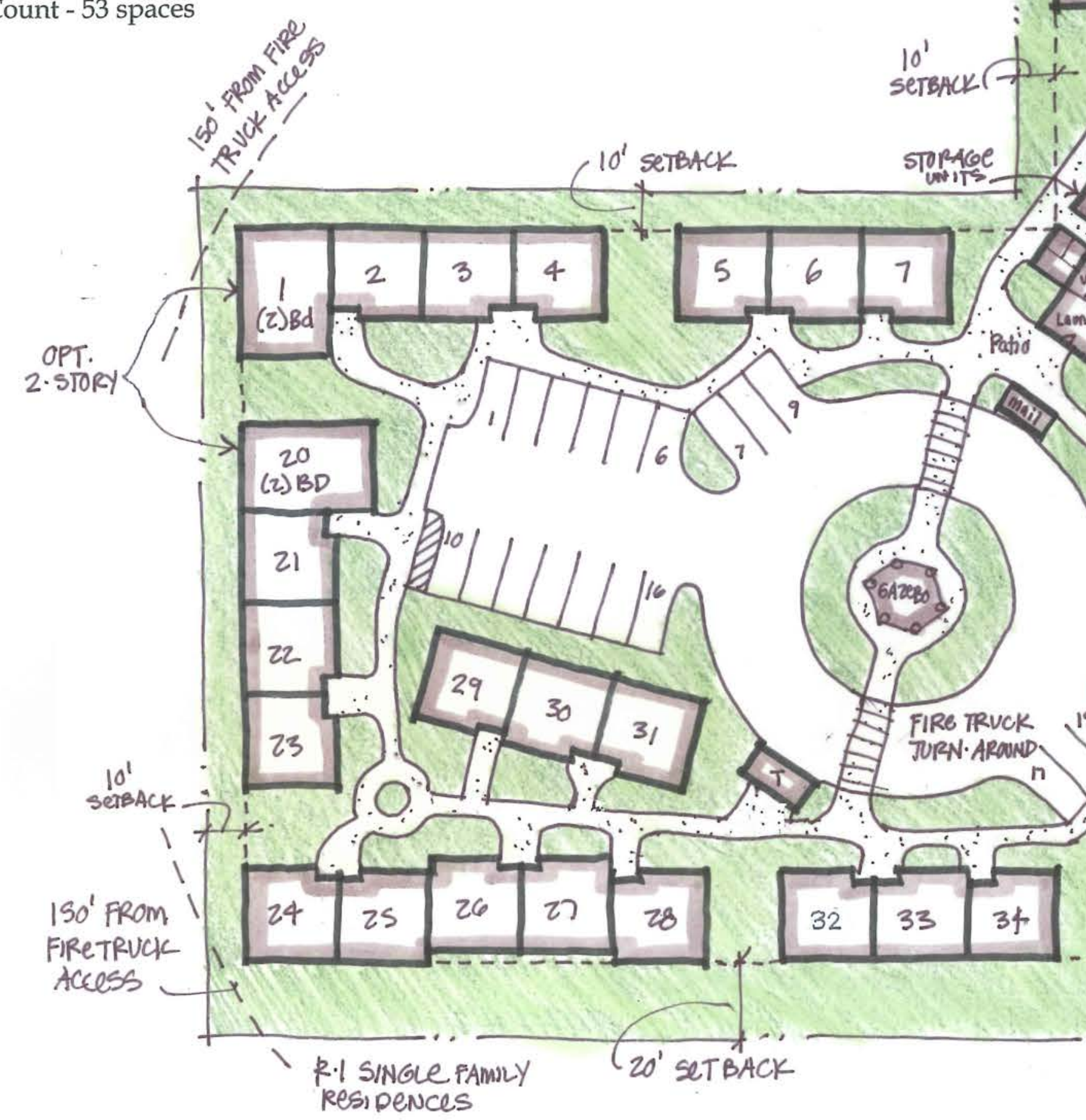

$10^{\prime}$ SeTBACK

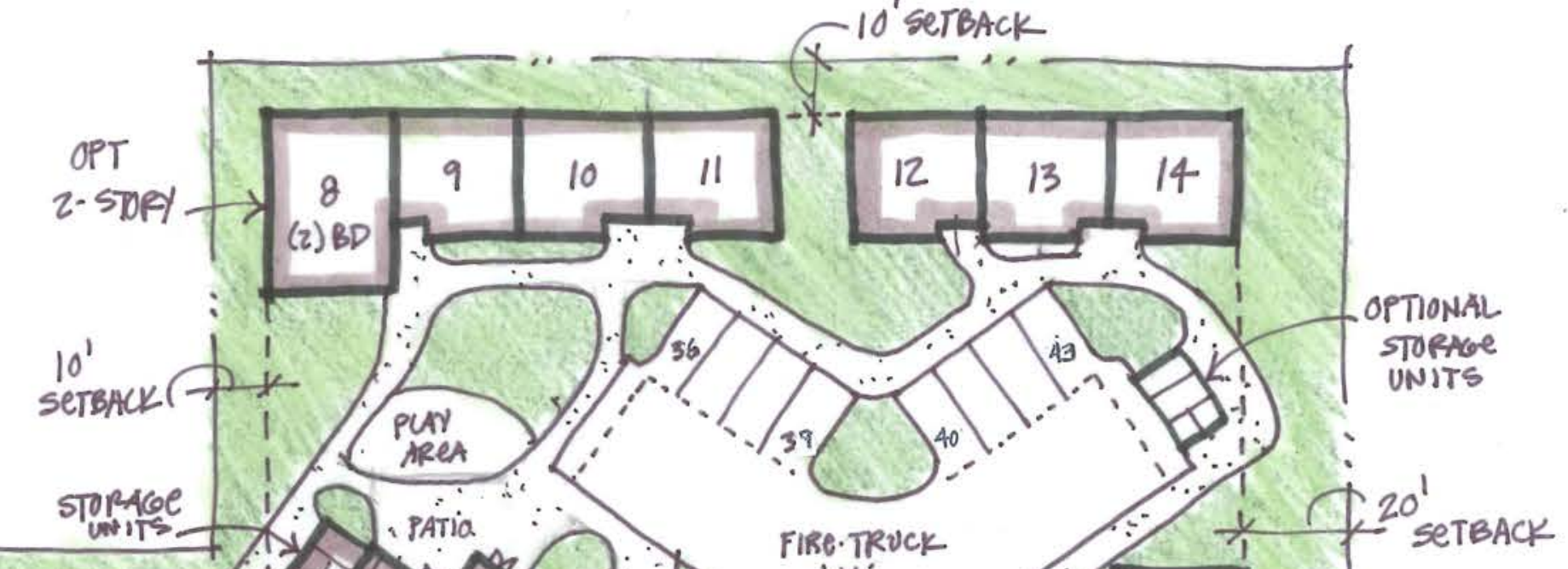
Grut (1)

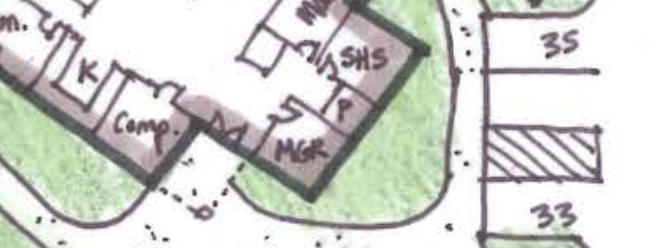
जiाiाin

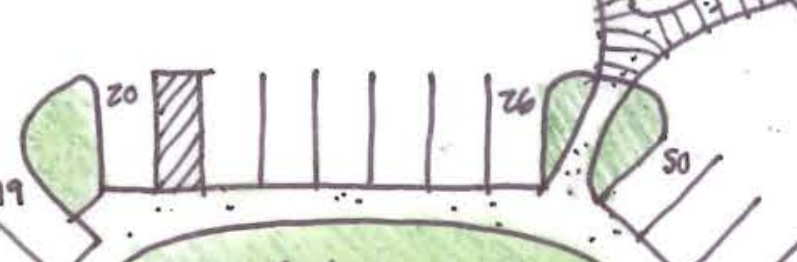
Ganden space

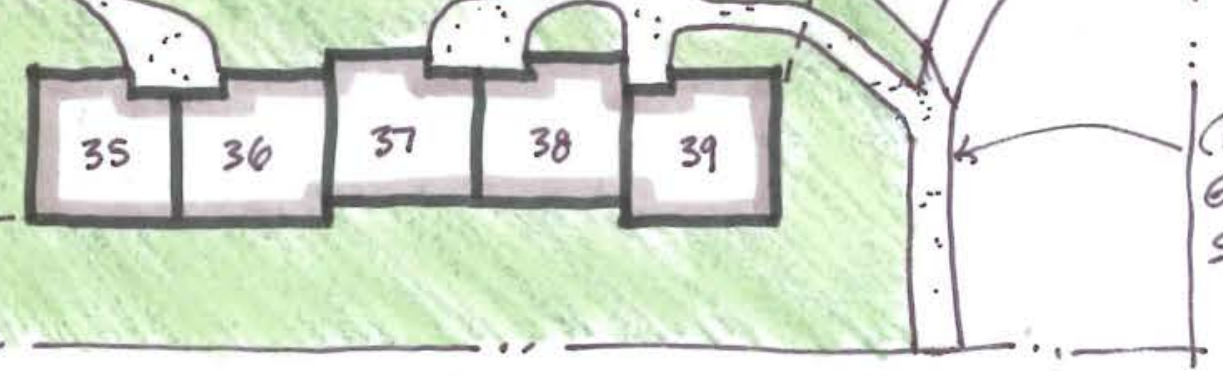

(E) CURB GUTTER द SIDEAYK

Bethel Street Senior Housing Feasibility People's Self Help Housing 5.15 .13 $1^{\prime \prime}=40^{\prime}$ 
2 Cities and Towns (Places)_1

Santa Maria city, CA (0669196) et al.

Geographies: 2 Places

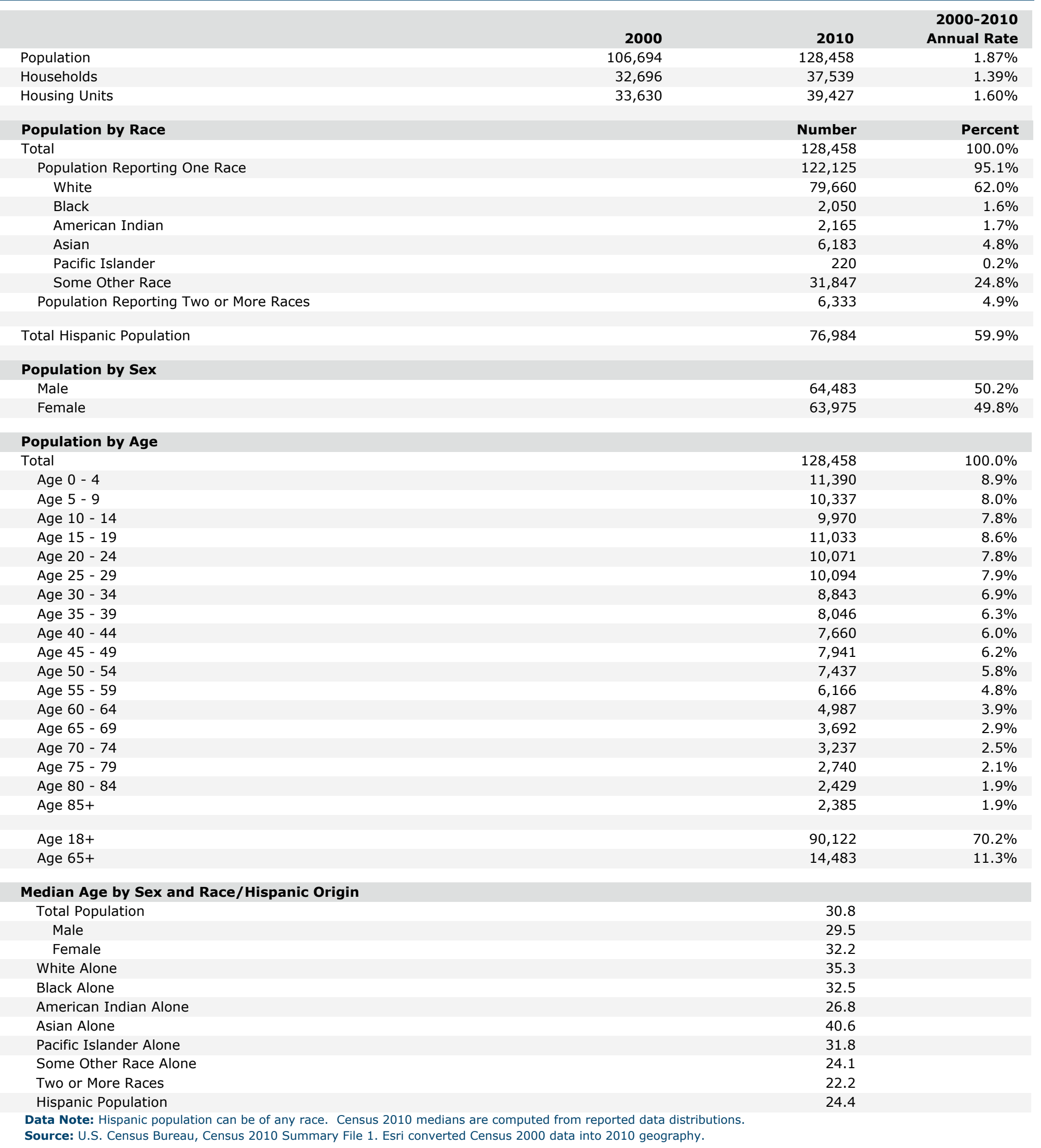


2 Cities and Towns (Places)_1

Santa Maria city, CA (0669196) et al.

Geographies: 2 Places

\section{Households by Type}

Total

Households with 1 Person

$\begin{array}{rr}37,539 & 100.0 \% \\ 7,358 & 19.6 \% \\ 30,181 & 80.4 \% \\ 28,362 & 75.6 \% \\ 20,888 & 55.6 \% \\ 10,714 & 28.5 \% \\ 7,474 & 19.9 \% \\ 3,980 & 10.6 \% \\ 1,819 & 4.8 \% \\ 16,861 & 44.9 \% \\ 3,084 & 8.2 \% \\ 2,418 & 6.4 \% \\ 2,171 & 5.8 \% \\ 247 & 0.7 \% \\ 3.39 & \end{array}$

Households with 2+ People

Family Households

Husband-wife Families

With Own Children

Other Family (No Spouse Present)

With Own Children

Nonfamily Households

All Households with Children

Multigenerational Households

nmarried Partner Households

Male-female

Same-sex

Average Household Size

$\begin{array}{rr}28,362 & 100.0 \% \\ 8,566 & 30.2 \% \\ 5,168 & 18.2 \% \\ 5,431 & 19.1 \% \\ 3,761 & 13.3 \% \\ 2,075 & 7.3 \% \\ 3,361 & 11.9 \% \\ 3.80 & \end{array}$

Family Households by Size

Total
2 People
3 People
4 People
5 People
6 People
7+ People

3.80

\section{Nonfamily Households by Size}

Total

1 Person
2 People
3 People
4 People
5 People
6 People
7+ People

$\begin{array}{rr}9,177 & 100.0 \% \\ 7,358 & 80.2 \% \\ 1,330 & 14.5 \% \\ 265 & 2.9 \% \\ 108 & 1.2 \% \\ 46 & 0.5 \% \\ 28 & 0.3 \% \\ 42 & 0.5 \% \\ 1.31 & \end{array}$

Average Nonfamily Size

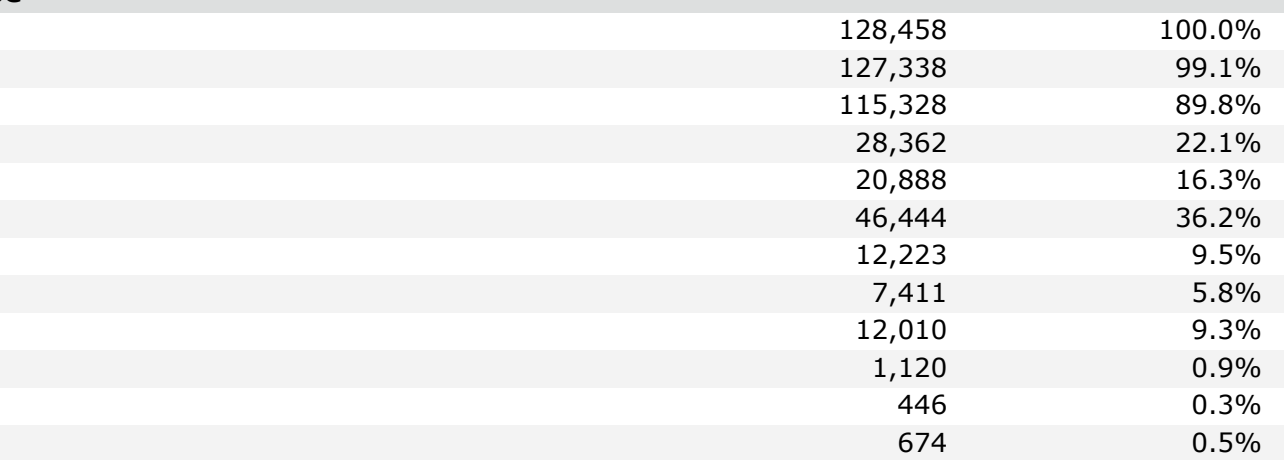

\section{Population by Relationship and Household Type}

Total

In Households

In Family Households

Householder

Spouse

Child

Other relative

Nonrelative

In Nonfamily Households

In Group Quarters

Institutionalized Population

Noninstitutionalized Population

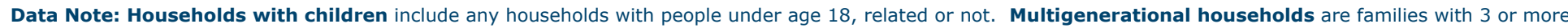

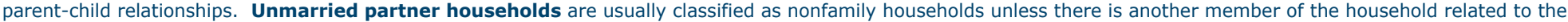

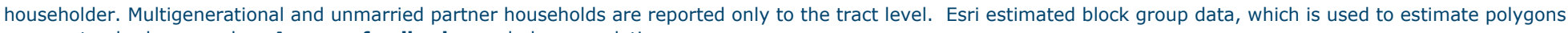
or non-standard geography. Average family size excludes nonrelatives.

Source: U.S. Census Bureau, Census 2010 Summary File 1. 
2 Cities and Towns (Places)_1

Santa Maria city, CA (0669196) et al.

Geographies: 2 Places

Family Households by Age of Householder Total

$\begin{array}{ll}\text { Householder Age } & 15-44 \\ \text { Householder Age } & 45-54 \\ \text { Householder Age } & 55-64 \\ \text { Householder Age } & 65-74 \\ \text { Householder Age } & 75+\end{array}$

$\begin{array}{rr}28,362 & 100.0 \% \\ 12,701 & 44.8 \% \\ 6,372 & 22.5 \% \\ 4,343 & 15.3 \% \\ 2,562 & 9.0 \% \\ 2,384 & 8.4 \%\end{array}$

\section{Nonfamily Households by Age of Householder}

Total

Householder Age $15-44$

Householder Age $45-54$

Householder Age $55-64$

Householder Age 65-74

Householder Age 75+

$\begin{array}{rr}9,177 & 100.0 \% \\ 2,094 & 22.8 \% \\ 1,372 & 15.0 \% \\ 1,666 & 18.2 \% \\ 1,498 & 16.3 \% \\ 2,547 & 27.8 \%\end{array}$

Households by Race of Householder

Total

Householder is White Alone

37,539

26,470

$100.0 \%$

Householder is Black Alone

715

$70.5 \%$

Householder is American Indian Alone

549

Householder is Asian Alone

1,814

$1.9 \%$

Householder is Pacific Islander Alone

67

Householder is Some Other Race Alone

6,485

$4.8 \%$

Householder is Two or More Races

1,439

$0.2 \%$

ouseholds with Hispanic Householder

16,344

$17.3 \%$

$3.8 \%$

$43.5 \%$

Husband-wife Families by Race of Householder

Total

Householder is White Alone

20,888

$100.0 \%$

Householder is Black Alone

14,278

$68.4 \%$

Householder is American Indian Alone

310

320

$1.5 \%$

Householder is Asian Alone

1,132

$1.5 \%$

Householder is Pacific Islander Alone

38

$5.4 \%$

Householder is Some Other Race Alone

4,050

$0.2 \%$

Householder is Two or More Races

Husband-wife Families with Hispanic Householder

10,091

$3.6 \%$

Other Families (No Spouse) by Race of Householder

Total

Householder is White Alone

7,474

$100.0 \%$

Householder is Black Alone

4,684

$62.7 \%$

189

$2.5 \%$

Householder is American Indian Alone

133

297

$1.8 \%$

Householder is Asian Alone

$4.0 \%$

Householder is Pacific Islander Alone

11

$0.1 \%$

Householder is Some Other Race Alone

$23.6 \%$

Householder is Two or More Races

1,762

$5.3 \%$

Other Families with Hispanic Householder

4,274

$57.2 \%$

Nonfamily Households by Race of Householder

Total

Householder is White Alone

9,177

$100.0 \%$

Householder is Black Alone

7,508

$81.8 \%$

Householder is American Indian Alone

216

$2.4 \%$

Householder is Asian Alone

96

$1.0 \%$

Householder is Pacific Islander Alone

$4.2 \%$

Householder is Some Other Race Alone

$0.2 \%$

Householder is Two or More Races

18

$7.3 \%$

673

$3.1 \%$

Nonfamily Households with Hispanic Householder

281

1,979

$21.6 \%$

Source: U.S. Census Bureau, Census 2010 Summary File 1. 
2 Cities and Towns (Places)_1

Santa Maria city, CA (0669196) et al.

Geographies: 2 Places

Total Housing Units by Occupancy

Total

Occupied Housing Units

39,427

37,539

Vacant Housing Units

For Rent

Rented, not Occupied

For Sale Only

Sold, not Occupied

For Seasonal/Recreational/Occasional Use

For Migrant Workers

Other Vacant

Total Vacancy Rate

$\begin{array}{rr}631 & 1.6 \% \\ 39 & 0.1 \% \\ 434 & 1.1 \% \\ 90 & 0.2 \% \\ 144 & 0.4 \% \\ 2 & 0.0 \% \\ 548 & 1.4 \% \\ 4.8 \% & \end{array}$

Households by Tenure and Mortgage Status

Total

37,539

22,197

$100.0 \%$

Owner Occupied

16,518

5,679

3.09

Owned Free and Clear

Average Household Size

15,342

3.83

Average Household Size

Owner-occupied Housing Units by Race of Householder

Total

Householder is White Alone

$\begin{array}{rr}22,197 & 100.0 \% \\ 17,162 & 77.3 \% \\ 309 & 1.4 \% \\ 224 & 1.0 \% \\ 1,251 & 5.6 \% \\ 36 & 0.2 \% \\ 2,564 & 11.6 \% \\ 651 & 2.9 \% \\ 7,214 & 32.5 \%\end{array}$

Householder is Black Alone

Householder is American Indian Alone

Householder is Asian Alone

Householder is Pacific Islander Alone

Householder is Some Other Race Alone

Householder is Two or More Races

Owner-occupied Housing Units with Hispanic Householder

$\begin{array}{rr}15,342 & 100.0 \% \\ 9,308 & 60.7 \% \\ 406 & 2.6 \% \\ 325 & 2.1 \% \\ 563 & 3.7 \% \\ 31 & 0.2 \% \\ 3,921 & 25.6 \% \\ 788 & 5.1 \% \\ 9,130 & 59.5 \%\end{array}$

Renter-occupied Housing Units by Race of Householder

Total

Householder is White Alone

Householder is Black Alone

Householder is American Indian Alone

Householder is Asian Alone

Householder is Pacific Islander Alone

Householder is Some Other Race Alone

Householder is Two or More Races

Renter-occupied Housing Units with Hispanic Householder

Average Household Size by Race/Hispanic Origin of Householder

Householder is White Alone

2.99

2.96

Householder is Black Alone

4.17

Householder is American Indian Alone

3.36

Householder is Asian Alone

2.96

Householder is Pacific Islander Alone

4.90

Householder is Some Other Race Alone

3.98

Householder is Two or More Races

4.59 
2 Cities and Towns (Places)_1

Santa Maria city, CA (0669196) et al.

Geographies: 2 Places

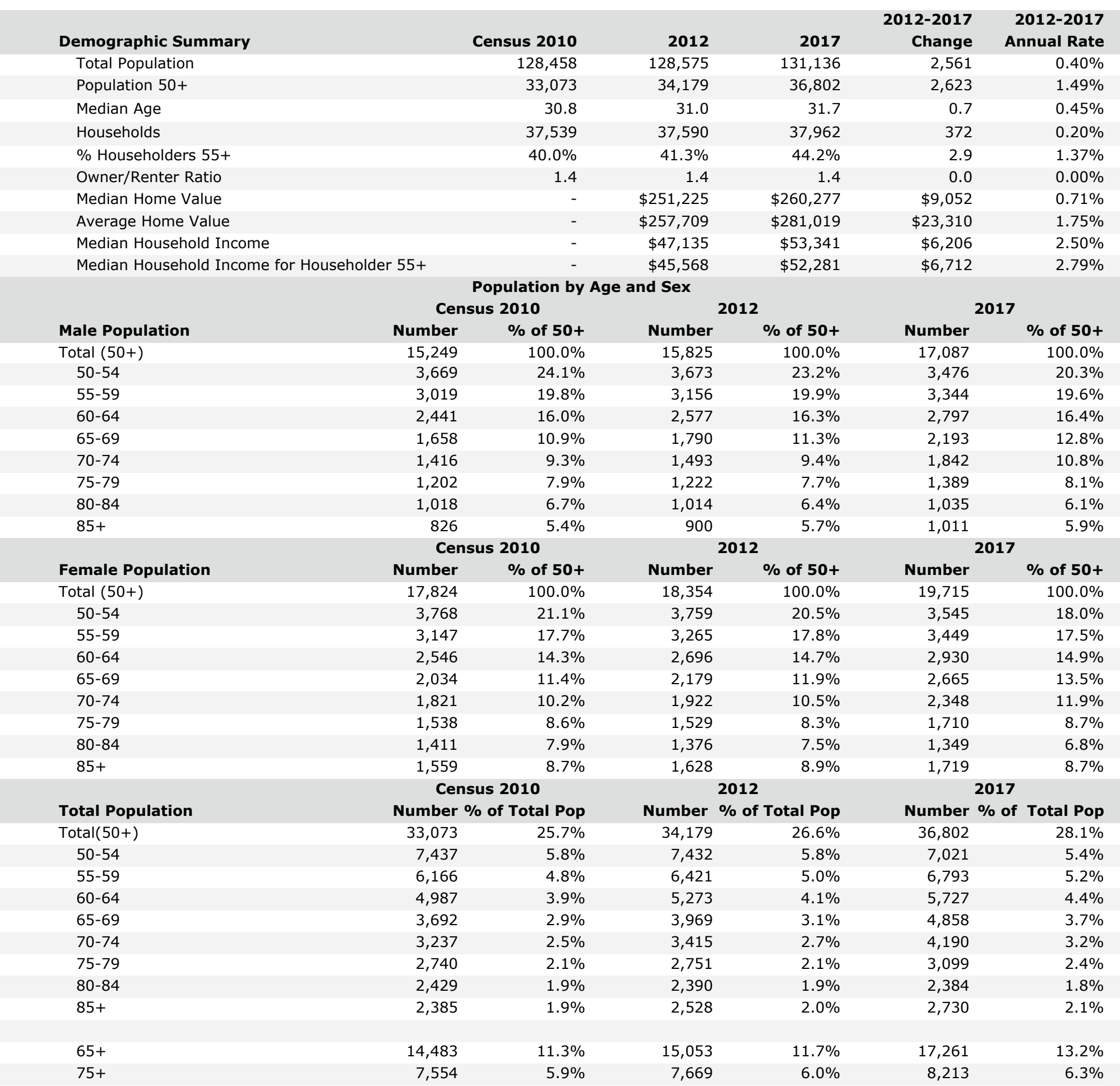


2 Cities and Towns (Places)_1

Santa Maria city, CA (0669196) et al.

Geographies: 2 Places

\begin{tabular}{|c|c|c|c|c|c|c|c|c|}
\hline \multicolumn{9}{|c|}{2012 Households by Income and Age of Householder 55+ } \\
\hline & $55-64$ & Percent & $65-74$ & Percent & $75+$ & Percent & Total & Percent \\
\hline Total & 6,258 & $100 \%$ & 4,297 & $100 \%$ & 4,983 & $100 \%$ & 15,538 & $100 \%$ \\
\hline$<\$ 15,000$ & 644 & $10.3 \%$ & 438 & $10.2 \%$ & 807 & $16.2 \%$ & 1,889 & $12.2 \%$ \\
\hline$\$ 15,000-\$ 24,999$ & 548 & $8.8 \%$ & 435 & $10.1 \%$ & 971 & $19.5 \%$ & 1,954 & $12.6 \%$ \\
\hline$\$ 25,000-\$ 34,999$ & 559 & $8.9 \%$ & 622 & $14.5 \%$ & 762 & $15.3 \%$ & 1,943 & $12.5 \%$ \\
\hline$\$ 35,000-\$ 49,999$ & 1,012 & $16.2 \%$ & 778 & $18.1 \%$ & 790 & $15.9 \%$ & 2,580 & $16.6 \%$ \\
\hline$\$ 50,000-\$ 74,999$ & 1,317 & $21.0 \%$ & 1,151 & $26.8 \%$ & 848 & $17.0 \%$ & 3,316 & $21.3 \%$ \\
\hline$\$ 75,000-\$ 99,999$ & 703 & $11.2 \%$ & 351 & $8.2 \%$ & 436 & $8.7 \%$ & 1,490 & $9.6 \%$ \\
\hline$\$ 100,000-\$ 149,999$ & 962 & $15.4 \%$ & 306 & $7.1 \%$ & 289 & $5.8 \%$ & 1,557 & $10.0 \%$ \\
\hline$\$ 150,000-\$ 199,999$ & 332 & $5.3 \%$ & 126 & $2.9 \%$ & 47 & $0.9 \%$ & 505 & $3.3 \%$ \\
\hline$\$ 200,000+$ & 181 & $2.9 \%$ & 90 & $2.1 \%$ & 33 & $0.7 \%$ & 304 & $2.0 \%$ \\
\hline Median HH Income & $\$ 54,974$ & & $\$ 46,832$ & & $\$ 34,158$ & & $\$ 45,568$ & \\
\hline Average $\mathrm{HH}$ Income & $\$ 72,051$ & & $\$ 58,948$ & & $\$ 45,573$ & & $\$ 59,936$ & \\
\hline \multicolumn{9}{|c|}{2017 Households by Income and Age of Householder 55+ } \\
\hline & $55-64$ & Percent & $65-74$ & Percent & $75+$ & Percent & Total & Percent \\
\hline Total & 6,508 & $100 \%$ & 5,097 & $100 \%$ & 5,172 & $100 \%$ & 16,777 & $100 \%$ \\
\hline$<\$ 15,000$ & 641 & $9.8 \%$ & 516 & $10.1 \%$ & 840 & $16.2 \%$ & 1,997 & $11.9 \%$ \\
\hline$\$ 15,000-\$ 24,999$ & 416 & $6.4 \%$ & 443 & $8.7 \%$ & 883 & $17.1 \%$ & 1,742 & $10.4 \%$ \\
\hline$\$ 25,000-\$ 34,999$ & 434 & $6.7 \%$ & 597 & $11.7 \%$ & 649 & $12.5 \%$ & 1,680 & $10.0 \%$ \\
\hline$\$ 35,000-\$ 49,999$ & 907 & $13.9 \%$ & 818 & $16.0 \%$ & 760 & $14.7 \%$ & 2,485 & $14.8 \%$ \\
\hline$\$ 50,000-\$ 74,999$ & 1,309 & $20.1 \%$ & 1,340 & $26.3 \%$ & 898 & $17.4 \%$ & 3,547 & $21.1 \%$ \\
\hline$\$ 75,000-\$ 99,999$ & 970 & $14.9 \%$ & 603 & $11.8 \%$ & 657 & $12.7 \%$ & 2,230 & $13.3 \%$ \\
\hline$\$ 100,000-\$ 149,999$ & 1,170 & $18.0 \%$ & 453 & $8.9 \%$ & 379 & $7.3 \%$ & 2,002 & $11.9 \%$ \\
\hline$\$ 150,000-\$ 199,999$ & 437 & $6.7 \%$ & 199 & $3.9 \%$ & 68 & $1.3 \%$ & 704 & $4.2 \%$ \\
\hline$\$ 200,000+$ & 224 & $3.4 \%$ & 128 & $2.5 \%$ & 38 & $0.7 \%$ & 390 & $2.3 \%$ \\
\hline Median HH Income & $\$ 64,006$ & & $\$ 52,022$ & & $\$ 38,279$ & & $\$ 52,281$ & \\
\hline Average $\mathrm{HH}$ Income & $\$ 82,327$ & & $\$ 66,691$ & & $\$ 50,800$ & & $\$ 67,858$ & \\
\hline
\end{tabular}


2 Cities and Towns (Places)_1

Santa Maria city, CA (0669196) et al.

Geographies: 2 Places

\begin{tabular}{|c|c|c|c|}
\hline 2012 Population $50+$ by Race & Number & Percent & \% Pop \\
\hline Total & 34,181 & $100.0 \%$ & $26.6 \%$ \\
\hline White Alone & 26,352 & $77.1 \%$ & $33.2 \%$ \\
\hline Black Alone & 506 & $1.5 \%$ & $25.3 \%$ \\
\hline American Indian Alone & 405 & $1.2 \%$ & $18.5 \%$ \\
\hline Asian Alone & 2,235 & $6.5 \%$ & $37.3 \%$ \\
\hline Pacific Islander Alone & 52 & $0.2 \%$ & $24.3 \%$ \\
\hline Some Other Race Alone & 3,725 & $10.9 \%$ & $11.5 \%$ \\
\hline Two or More Races & 906 & $2.7 \%$ & $14.2 \%$ \\
\hline Hispanic Origin (Any Race) & 11,041 & $32.3 \%$ & $14.1 \%$ \\
\hline Census 2010 Households and Age of Householder & Number & Percent & \% Total HHs \\
\hline Total & 15,000 & $100.0 \%$ & $40.0 \%$ \\
\hline Family Households & 9,289 & $61.9 \%$ & $24.7 \%$ \\
\hline Householder Age 55-64 & 4,343 & $29.0 \%$ & $11.6 \%$ \\
\hline Householder Age 65-74 & 2,562 & $17.1 \%$ & $6.8 \%$ \\
\hline Householder Age 75-84 & 1,785 & $11.9 \%$ & $4.8 \%$ \\
\hline Householder Age 85+ & 599 & $4.0 \%$ & $1.6 \%$ \\
\hline Nonfamily Households & 5,711 & $38.1 \%$ & $15.2 \%$ \\
\hline Householder Age 55-64 & 1,666 & $11.1 \%$ & $4.4 \%$ \\
\hline Householder Age 65-74 & 1,498 & $10.0 \%$ & $4.0 \%$ \\
\hline Householder Age 75-84 & 1,570 & $10.5 \%$ & $4.2 \%$ \\
\hline Householder Age 85+ & 977 & $6.5 \%$ & $2.6 \%$ \\
\hline Census 2010 Occupied Housing Units by Age of Householder & Number & Percent & \% Total HHs \\
\hline Total & 15,000 & $100.0 \%$ & $40.0 \%$ \\
\hline Owner Occupied Housing Units & 11,493 & $76.6 \%$ & $30.6 \%$ \\
\hline Householder Age 55-64 & 4,413 & $29.4 \%$ & $11.8 \%$ \\
\hline Householder Age 65-74 & 3,219 & $21.5 \%$ & $8.6 \%$ \\
\hline Householder Age 75-84 & 2,703 & $18.0 \%$ & $7.2 \%$ \\
\hline Householder Age $85+$ & 1,158 & $7.7 \%$ & $3.1 \%$ \\
\hline Renter Occupied Housing Units & 3,507 & $23.4 \%$ & $9.3 \%$ \\
\hline Householder Age 55-64 & 1,596 & $10.6 \%$ & $4.3 \%$ \\
\hline Householder Age 65-74 & 841 & $5.6 \%$ & $2.2 \%$ \\
\hline Householder Age 75-84 & 652 & $4.3 \%$ & $1.7 \%$ \\
\hline Householder Age 85+ & 418 & $2.8 \%$ & $1.1 \%$ \\
\hline
\end{tabular}

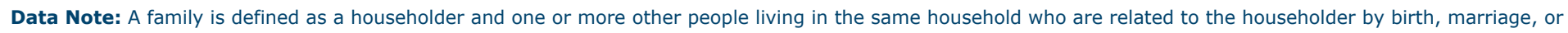

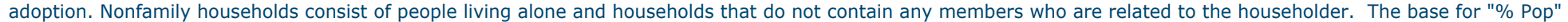
is specific to the row. A Nonrelative is not related to the householder by birth, marriage, or adoption.

Source: U.S. Census Bureau, Census 2010 Summary File 1. Esri forecasts for 2012 and 2017. 
2 Cities and Towns (Places)_1

Santa Maria city, CA (0669196) et al.

Geographies: 2 Places

$\begin{array}{lr}\text { Summary } & \text { Census } \mathbf{2 0 1 0} \\ \text { Population } & 128,458 \\ \text { Households } & 37,539 \\ \text { Families } & 28,362 \\ \text { Average Household Size } & 3.39 \\ \text { Owner Occupied Housing Units } & 22,197 \\ \text { Renter Occupied Housing Units } & 15,342 \\ \text { Median Age } & 30.8 \\ \text { Trends: 2012 - 2017 Annual Rate } & \text { Area } \\ \text { Population } & 0.40 \% \\ \text { Households } & 0.20 \% \\ \text { Families } & 0.34 \% \\ \text { Owner HHs } & 0.63 \% \\ \text { Median Household Income } & 2.50 \%\end{array}$

\section{Households by Income}

$<\$ 15,000$

$\$ 15,000-\$ 24,999$

$\$ 25,000-\$ 34,999$

$\$ 35,000-\$ 49,999$

$\$ 50,000$ - $\$ 74,999$

$\$ 75,000-\$ 99,999$

$\$ 100,000-\$ 149,999$

$\$ 150,000-\$ 199,999$

$\$ 200,000+$

Median Household Income

Average Household Income

Per Capita Income

\section{Population by Age}

$$
\begin{aligned}
& 0-4 \\
& 5-9 \\
& 10-14 \\
& 15-19 \\
& 20-24 \\
& 25-34 \\
& 35-44 \\
& 45-54 \\
& 55-64 \\
& 65-74 \\
& 75-84 \\
& 85+
\end{aligned}
$$

Race and Ethnicity

White Alone

Black Alone

American Indian Alone

Asian Alone

Pacific Islander Alone

Some Other Race Alone

Two or More Races

(1)

Hispanic Origin (Any Race)

Data Note: Income is expressed in current dollars.

Source: U.S. Census Bureau, Census 2010 Summary File 1. Esri forecasts for 2012 and 2017.

\begin{tabular}{rr}
\multicolumn{2}{c}{ Census 2010} \\
Number & Percent \\
11,390 & $8.9 \%$ \\
10,337 & $8.0 \%$ \\
9,970 & $7.8 \%$ \\
11,033 & $8.6 \%$ \\
10,071 & $7.8 \%$ \\
18,937 & $14.7 \%$ \\
15,706 & $12.2 \%$ \\
15,378 & $12.0 \%$ \\
11,153 & $8.7 \%$ \\
6,929 & $5.4 \%$ \\
5,169 & $4.0 \%$ \\
2,385 & $1.9 \%$ \\
\hline
\end{tabular}

Number

79,660

2,050

2,165

6,183

220

31,847

6,333

76,984
Percent

$62.0 \%$

$1.7 \%$

$4.8 \%$

$0.2 \%$

$24.8 \%$

$4.9 \%$

$59.9 \%$

\section{Census 2010}

$1.6 \%$
2012

128,575

37,590

28,213

3.39

21,699

15,891

31.0

State

$0.00 \%$

$0.00 \%$

$0.00 \%$

$0.00 \%$

$0.00 \%$

2012

Number

4,573

4,375

4,436

6,330

8,180

3,797

3,985

1,227

686

Percent

$11.6 \%$

$11.8 \%$

$16.8 \%$

$21.8 \%$

$10.1 \%$

$10.6 \%$

$3.3 \%$

$1.8 \%$

$\$ 47,135$

$\$ 60,710$

$\$ 18,039$

20

Number

11,357

10,297

9,834

10,524

10,275

19,275

15,322

14,945

11,694

7,384

5,141

2,528

2

Number

79,348

1,999

2,189

5,984

214

32,474

6,367

78,511

$61.1 \%$

Percent

$8.8 \%$

$8.0 \%$

$7.6 \%$

$8.2 \%$

$8.0 \%$

$15.0 \%$

$11.9 \%$

$11.6 \%$

$9.1 \%$

$5.7 \%$

$4.0 \%$

$2.0 \%$

012

Percent

$61.7 \%$

$1.6 \%$

$1.7 \%$

$4.7 \%$

$0.2 \%$

$25.3 \%$

$5.0 \%$

4,510

3,624

3,519

5,731

8,175

5,231

4,758

1,586

827

2017

131,136

37,962

28,695

3.42

22,392

15,570

31.7

National

$0.68 \%$

$0.74 \%$

$0.72 \%$

$0.91 \%$

$2.55 \%$

2017

Percent

$11.9 \%$

$9.5 \%$

$9.3 \%$

$15.1 \%$

$21.5 \%$

$13.8 \%$

$12.5 \%$

$4.2 \%$

$2.2 \%$

$\$ 53,341$

$\$ 68,452$

$\$ 20,111$

2017

Number Percent

$11,618 \quad 8.9 \%$

$10,493 \quad 8.0 \%$

$10,153 \quad 7.7 \%$

$10,227 \quad 7.8 \%$

$9,466 \quad 7.2 \%$

$19,822 \quad 15.1 \%$

$15,395 \quad 11.7 \%$

$14,180 \quad 10.8 \%$

$12,520 \quad 9.5 \%$

$9,048 \quad 6.9 \%$

$5,483 \quad 4.2 \%$

2,730

$2.1 \%$

2017

Number Percent

$80,104 \quad 61.1 \%$

$1,953 \quad 1.5 \%$

$2,265 \quad 1.7 \%$

$5,898 \quad 4.5 \%$

$208 \quad 0.2 \%$

$34,216 \quad 26.1 \%$

$6,493 \quad 5.0 \%$

$83,517 \quad 63.7 \%$ 
Trends 2012-2017

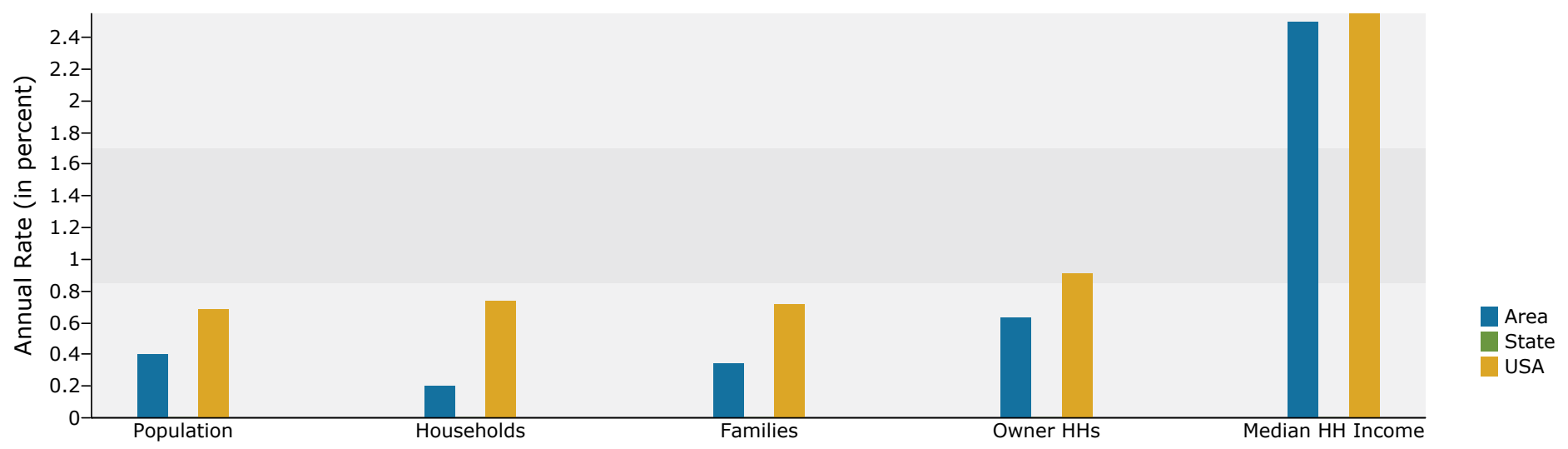

Population by Age

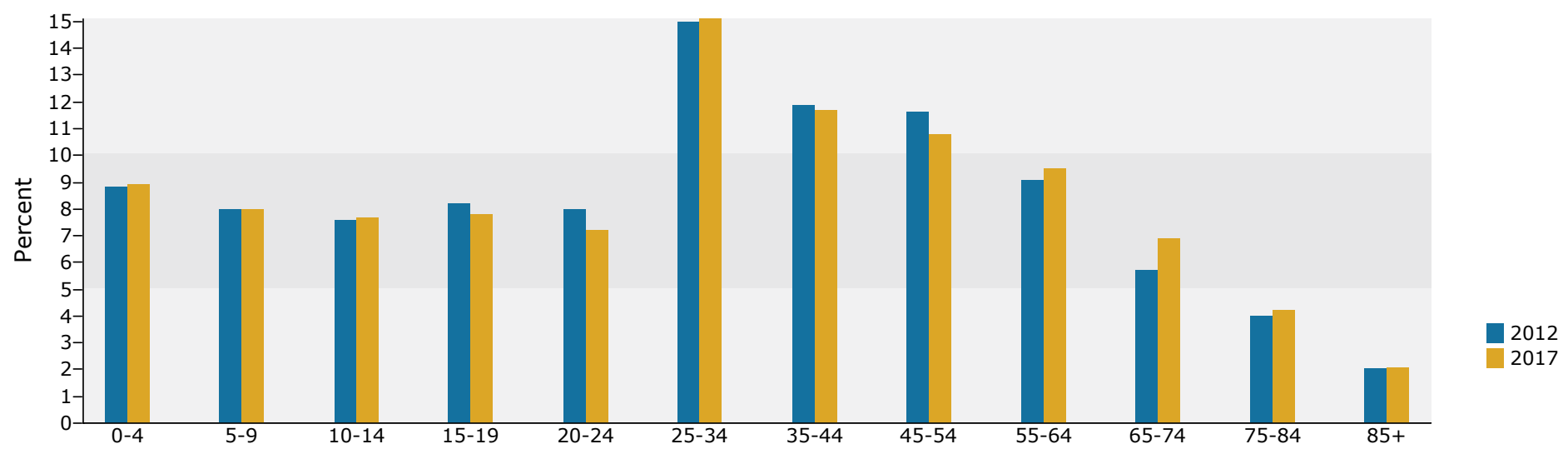

2012 Household Income

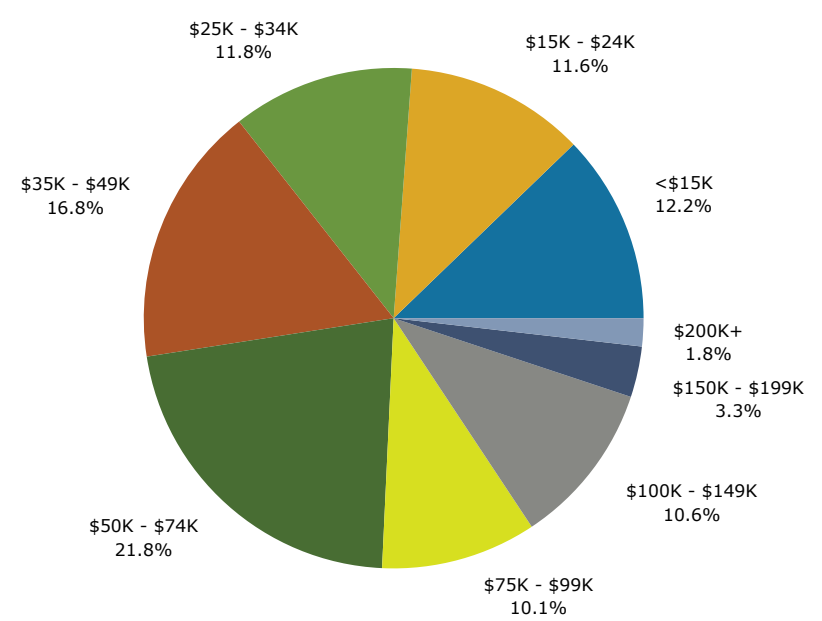

2012 Population by Race

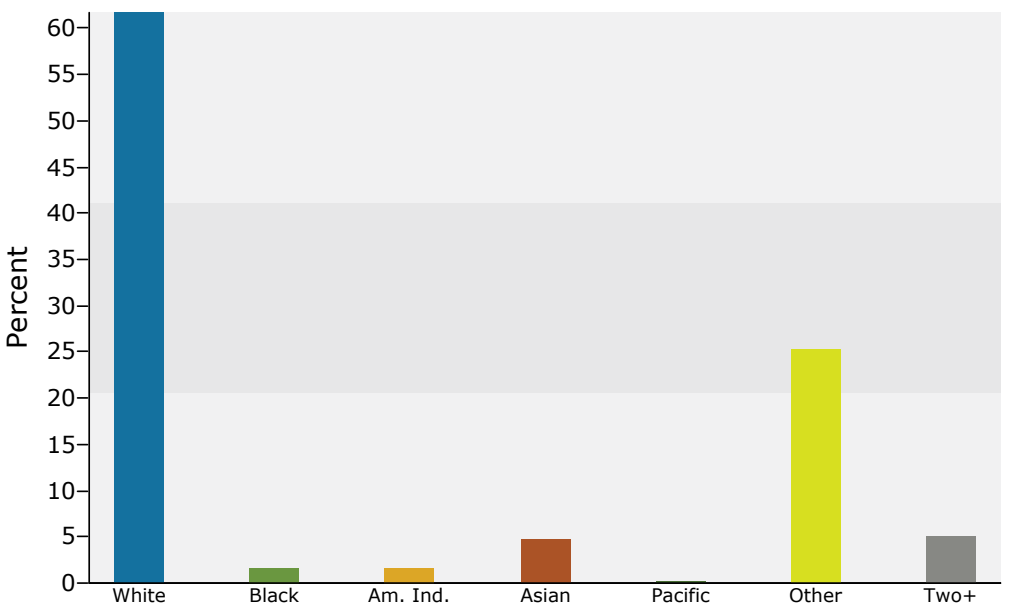

2012 Percent Hispanic Origin: 61.1\% 
2 Cities and Towns (Places)_1

Santa Maria city, CA (0669196) et al.

Geographies: 2 Places

Population Summary

2000 Total Population

2010 Total Population

Santa Maria city, CA (066...

2012 Total Population

106,694

2012 Group Quarters

128,458

128,575

2017 Total Population

1,118

2012-2017 Annual Rate

131,136

$0.40 \%$

Household Summary

2000 Households

2000 Average Household Size

2010 Households

37,539

2010 Average Household Size

2012 Households

37,590

2012 Average Household Size

2017 Households

37,962

2017 Average Household Size

2012-2017 Annual Rate

$0.20 \%$

2010 Families

2010 Average Family Size

28,362

012 Families

2012 Average Family Size

28,213

3.80

2017 Families

28,695

2017 Average Family Size

2012-2017 Annual Rate

Housing Unit Summary

2000 Housing Units

Owner Occupied Housing Units

Renter Occupied Housing Units

Vacant Housing Units

$2.8 \%$

2010 Housing Units

39,427

Owner Occupied Housing Units

$56.3 \%$

Renter Occupied Housing Units

Vacant Housing Units

$4.8 \%$

2012 Housing Units

39,714

Owner Occupied Housing Units

Renter Occupied Housing Units

Vacant Housing Units

$5.3 \%$

2017 Housing Units

40,344

Owner Occupied Housing Units

Renter Occupied Housing Units

Vacant Housing Units

\section{Median Household Income}

2012

2017

\section{Median Home Value}

2012

2017

Per Capita Income

2012

Median Age

2010

2012

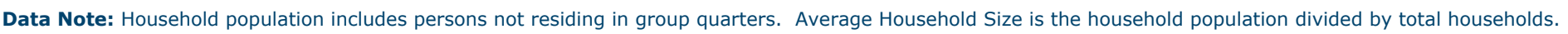

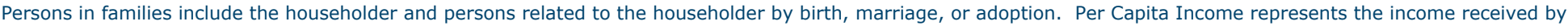
all persons aqed 15 vears and over divided bv the total population. 


\section{Market Profile}

2 Cities and Towns (Places)_1

Santa Maria city, CA (0669196) et al.

Geographies: 2 Places

2012 Households by Income

Santa Maria city, CA (066...

Household Income Base

$<\$ 15,000$

$\$ 15,000-\$ 24,999$

$\$ 25,000-\$ 34,999$

$\$ 35,000-\$ 49,999$

$\$ 50,000-\$ 74,999$

$\$ 75,000-\$ 99,999$

$\$ 100,000-\$ 149,999$

37,589

$\$ 150,000-\$ 199,999$

$12.2 \%$

$11.6 \%$

$11.8 \%$

$\$ 200,000+$

$16.8 \%$

$21.8 \%$

$10.1 \%$

$10.6 \%$

$3.3 \%$

$1.8 \%$

Average Household Income

$\$ 60,710$

2017 Households by Income

Household Income Base

37,961

$<\$ 15,000$

$11.9 \%$

$\$ 15,000-\$ 24,999$

$\$ 25,000-\$ 34,999$

$\$ 35,000$ - \$49,999

$\$ 50,000-\$ 74,999$

$9.5 \%$

$\$ 75,000-\$ 99,999$

$9.3 \%$

$\$ 100,000$ - \$149,999

$15.1 \%$

$21.5 \%$

$\$ 150,000$ - $\$ 199,999$

$13.8 \%$

$12.5 \%$

$\$ 200,000+$

$4.2 \%$

$2.2 \%$

Average Household Income

$\$ 68,452$

2012 Owner Occupied Housing Units by Value

Total

$<\$ 50,000$

$\$ 50,000-\$ 99,999$

$\$ 100,000-\$ 149,999$

21,695

$2.8 \%$

$11.7 \%$

$\$ 150,000-\$ 199,999$

$7.1 \%$

$\$ 200,000-\$ 249,999$

$10.3 \%$

$\$ 250,000-\$ 299,999$

$17.7 \%$

$\$ 300,000-\$ 399,999$

$19.1 \%$

$\$ 400,000-\$ 499,999$

$20.9 \%$

$\$ 500,000-\$ 749,999$

$6.7 \%$

$\$ 750,000-\$ 999,999$

$3.2 \%$

$\$ 1,000,000+$

$0.5 \%$

$0.2 \%$

Average Home Value

2017 Owner Occupied Housing Units by Value

Total

$\$ 257,709$

$<\$ 50,000$

22,387

$\$ 50,000$ - $\$ 99,999$

$2.2 \%$

$\$ 100,000$ - \$149,999

$\$ 150,000$ - \$199,999

$\$ 200,000-\$ 249,999$

$11.7 \%$

$\$ 250,000-\$ 299,999$

$19.5 \%$

$\$ 300,000$ - \$399,999

$16.5 \%$

$\$ 400,000$ - \$499,999

$20.8 \%$

$\$ 500,000-\$ 749,999$

$10.5 \%$

$\$ 750,000-\$ 999,999$

$4.7 \%$

$\$ 1,000,000+$

$0.8 \%$

$0.2 \%$

Average Home Value

$\$ 281,019$

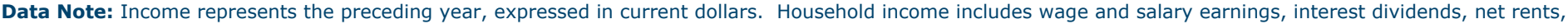

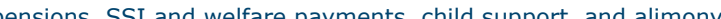

Source: U.S. Census Bureau, Census 2010 Summary File 1. Esri forecasts for 2012 and 2017. Esri converted Census 2000 data into 2010 geography. 


\section{Market Profile}

2 Cities and Towns (Places)_1

Santa Maria city, CA (0669196) et al.

Geographies: 2 Places

2010 Population by Age

Total

$0-4$

$5-9$

$10-14$

$15-24$

$25-34$

$35-44$

$45-54$

$55-64$

$65-74$

$75-84$

$85+$

$18+$

2012 Population by Age

Total

$0-4$

$5-9$

$10-14$

$15-24$

$25-34$

$35-44$

$45-54$

$55-64$

$65-74$

$75-84$

$85+$

$18+$

2017 Population by Age

Total

$$
0-4
$$

$5-9$

$10-14$

$15-24$

$25-34$

$35-44$

$45-54$

$55-64$

$65-74$

$75-84$

$85+$

$18+$

2010 Population by Sex

Males

Females

2012 Population by Sex

Males

Females

2017 Population by Sex

Males

Females
Santa Maria city, CA (066...

128,458

$8.9 \%$

$8.0 \%$

$7.8 \%$

$16.4 \%$

$14.7 \%$

$12.2 \%$

$12.0 \%$

$8.7 \%$

$5.4 \%$

$4.0 \%$

$1.9 \%$

$70.2 \%$

128,576

$8.8 \%$

$8.0 \%$

$7.6 \%$

$16.2 \%$

$15.0 \%$

$11.9 \%$

$11.6 \%$

$9.1 \%$

$5.7 \%$

$4.0 \%$

$2.0 \%$

$70.6 \%$

131,135

$8.9 \%$

$8.0 \%$

$7.7 \%$

$15.0 \%$

$15.1 \%$

$11.7 \%$

$10.8 \%$

$9.5 \%$

$6.9 \%$

$4.2 \%$

$2.1 \%$

$70.7 \%$

64,483

63,975

64,658

63,918

65,884

65,251 
2 Cities and Towns (Places)_1

Santa Maria city, CA (0669196) et al.

Geographies: 2 Places

2010 Population by Race/Ethnicity

Total

White Alone

Santa Maria city, CA (066...

Black Alone

128,458

American Indian Alone

Asian Alone

Pacific Islander Alone

$62.0 \%$

$1.6 \%$

$1.7 \%$

$4.8 \%$

Some Other Race Alone

$0.2 \%$

Two or More Races

$24.8 \%$

$4.9 \%$

Hispanic Origin

$59.9 \%$

Diversity Index

2012 Population by Race/Ethnicity

Total

128,575

White Alone

$61.7 \%$

Black Alone

$1.6 \%$

American Indian Alone

Asian Alone

$1.7 \%$

Pacific Islander Alone

$4.7 \%$

Some Other Race Alone

$0.2 \%$

Two or More Races

$25.3 \%$

Hispanic Origin

Diversity Index

$5.0 \%$

$61.1 \%$

2017 Population by Race/Ethnicity

Total

131,137

White Alone

$61.1 \%$

Black Alone

American Indian Alone

$1.7 \%$

Asian Alone

$4.5 \%$

Pacific Islander Alone

Some Other Race Alone

Two or More Races

Hispanic Origin

$63.7 \%$

Diversity Index

2010 Population by Relationship and Household Type

Total

In Households

In Family Households

Householder

Spouse

Child

Other relative

Nonrelative

In Nonfamily Households

$9.3 \%$

In Group Quarters

$0.9 \%$

Institutionalized Population

$0.3 \%$

Noninstitutionalized Population 
2 Cities and Towns (Places)_1

Santa Maria city, CA (0669196) et al.

Geographies: 2 Places

\section{Households by Type}

Santa Maria city, CA (066...

Total

Households with 1 Person

37,539

Households with 2+ People

$19.6 \%$

Family Households

Husband-wife Families

$80.4 \%$

$75.6 \%$

With Related Children

$55.6 \%$

Other Family (No Spouse Present)

$31.2 \%$

Other Family with Male Householder

With Related Children

Other Family with Female Householder

With Related Children

Nonfamily Households

All Households with Children

Multigenerational Households

Unmarried Partner Households

Male-female

Same-sex

2010 Households by Size

Total

1 Person Household

2 Person Household

3 Person Household

4 Person Household

5 Person Household

6 Person Household

7 + Person Household

2010 Households by Tenure and Mortgage Status

Total

Owner Occupied

Owned with a Mortgage/Loan

Owned Free and Clear

Renter Occupied

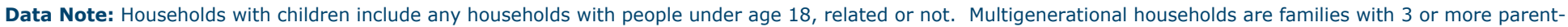

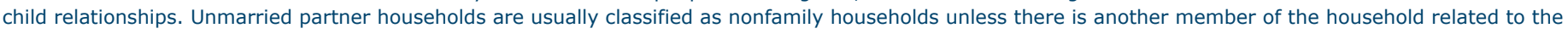

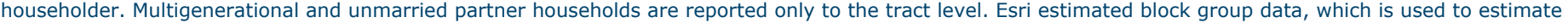
nolvannc or nnn-ctandard aenaranhv 


\section{Housing Profile}

2 Cities and Towns (Places)_1

Santa Maria city, CA (0669196) et al.

Geographies: 2 Places

\section{Population}

2010 Total Population

2012 Total Population

2017 Total Population

2012-2017 Annual Rate

128,458
128,575
131,136
$0.40 \%$

Households

2012 Median Household Income

2017 Median Household Income

2012-2017 Annual Rate
$\$ 47,135$

$\$ 53,341$

$2.50 \%$

Housing Units by Occupancy Status and Tenure

Total Housing Units

Occupied

Owner

Renter

Vacant

Cens
39,427
37,539
22,197
15,342
1,888

ensus 2010

Percent

Number
39,714
37,590
21,699
15,891
2,124

2012

Percent $100.0 \%$

$94.7 \%$

$54.6 \%$

$40.0 \%$

$5.3 \%$

$4.8 \%$

2,124

\begin{tabular}{rr}
\multicolumn{2}{c}{2012} \\
Number & Percent \\
21,695 & $100.0 \%$ \\
617 & $2.8 \%$ \\
2,536 & $11.7 \%$ \\
1,531 & $7.1 \%$ \\
2,225 & $10.3 \%$ \\
3,837 & $17.7 \%$ \\
4,143 & $19.1 \%$ \\
4,528 & $20.9 \%$ \\
1,444 & $6.7 \%$ \\
699 & $3.2 \%$ \\
102 & $0.5 \%$ \\
33 & $0.2 \%$
\end{tabular}

$\$ 251,225$

Median Value

$\$ 257,709$

2017

Number

40,344

37,962

22,392

15,570

2,382

Number

22,387

487

1,829

1,135

2,628

4,355

3,695

4,658

2,340

1,042

168

50

Percent

100.0\%

$94.1 \%$

$55.5 \%$

$38.6 \%$

$5.9 \%$

\section{Percent}

$100.0 \%$

$2.2 \%$

$8.2 \%$

$5.1 \%$

$11.7 \%$

$19.5 \%$

$16.5 \%$

$20.8 \%$

$10.5 \%$

$4.7 \%$

$0.8 \%$

$0.2 \%$

Average Value

$\$ 260,277$

$\$ 281,019$ 


\section{Housing Profile}

2 Cities and Towns (Places)_1

Santa Maria city, CA (0669196) et al.

Geographies: 2 Places

Census 2010 Owner Occupied Housing Units by Mortgage Status

Total

Owned with a Mortgage/Loan

22,197

Percent

Owned Free and Clear

16,518

$100.0 \%$

5,679

$74.4 \%$

$25.6 \%$

Census 2010 Vacant Housing Units by Status

Total

For Rent

Rented- Not Occupied

For Sale Only

Sold - Not Occupied

Seasonal/Recreational/Occasional Use

For Migrant Workers

Other Vacant
Number

1,888

631

39

434

90

144

2

548
Percent

$100.0 \%$

$33.4 \%$

$2.1 \%$

$23.0 \%$

$4.8 \%$

$7.6 \%$

$0.1 \%$

$29.0 \%$

Census 2010 Occupied Housing Units by Age of Householder and Home Ownership

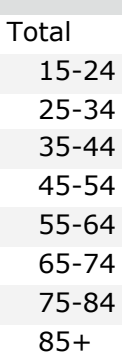

Census 2010 Occupied Housing Units by Race/Ethnicity of Householder and Home Ownership

Total

White Alone

Black/African American

American Indian/Alaska

Asian Alone

Pacific Islander Alone

Other Race Alone

Two or More Races

Hispanic Origin
Occupied Units

37,539

1,406

6,247

7,142

7,744

6,009

4,060

3,355

1,576
Owner Occupied Units Number

22,197 $\%$ of Occupied

249

2,007

3,502

4,946

4,413

3,219

2,703

1,158

\section{$59.1 \%$}

$17.7 \%$

$32.1 \%$

$49.0 \%$

$63.9 \%$

$73.4 \%$

$79.3 \%$

$80.6 \%$

$73.5 \%$
Owner Occupied Units Number \% of Occupied

22,197

17,162

$59.1 \%$

26,470

715

549

1,814

67

6,485

1,439

16,344
309

224

1,251

36

2,564

651

7,214
$64.8 \%$

$43.2 \%$

$40.8 \%$

$69.0 \%$

$53.7 \%$

$39.5 \%$

$45.2 \%$

$44.1 \%$

\section{Census 2010 Occupied Housing Units by Size and Home Ownership}

$$
\begin{aligned}
& \text { Total } \\
& \text { 1-Person } \\
& \text { 2-Person } \\
& \text { 3-Person } \\
& \text { 4-Person } \\
& \text { 5-Person } \\
& \text { 6-Person } \\
& \text { 7+ Person }
\end{aligned}
$$

\section{Occupied Units}

37,539

7,358

9,896

5,433

5,539

3,807

2,103

3,403
Owner Occupied Units Number \% of Occupied 22,197

4,281

7,270

3,156

3,171

1,975

983

1,361
$59.1 \%$

$58.2 \%$

$73.5 \%$

$58.1 \%$

$57.2 \%$

$51.9 \%$

$46.7 \%$

$40.0 \%$

Data Note: Persons of Hispanic Origin may be of any race.

Source: U.S. Census Bureau, Census 2010 Summary File 1. 


\section{Household Income Profile}

2 Cities and Towns (Places)_1

Santa Maria city, CA (0669196) et al.

Geographies: 2 Places

Population

Households

Median Age

Average Household Size

$\mathbf{2 0 1 2}$
128,575
37,590
31.0
3.39

Households by Income

Household

$<\$ 15,000$

$\$ 15,000-\$ 24,999$

$\$ 25,000-\$ 34,999$

$\$ 35,000-\$ 49,999$

$\$ 50,000-\$ 74,999$

$\$ 75,000-\$ 99,999$

$\$ 100,000-\$ 149,999$

$\$ 150,000-\$ 199,999$

$\$ 200,000+$

Median Household Income

Average Household Income

Per Capita Income

2017
131,136
37,962
31.7
3.42

2012

2012-2017

Change

2,561

0.03

\begin{tabular}{r} 
Number \\
\hline 37,589 \\
4,573 \\
4,375 \\
4,436 \\
6,330 \\
8,180 \\
3,797 \\
3,985 \\
1,227 \\
686
\end{tabular}

$\$ 47,135$

$\$ 60,710$

$\$ 18,039$
372

0.7

2012-2017

Annual Rate

$0.40 \%$

$0.20 \%$

$0.45 \%$

$0.18 \%$

2017

Number

37,961

4,510

3,624

3,519

5,731

8,175

5,231

4,758

1,586

827

$\$ 53,341$

$\$ 68,452$

$\$ 20,111$ 


\section{Household Income Profile}

2 Cities and Towns (Places)_1

Santa Maria city, CA (0669196) et al.

Geographies: 2 Places

\begin{tabular}{|c|c|c|c|c|c|c|c|}
\hline \multicolumn{8}{|c|}{2012 Households by Income and Age of Householder } \\
\hline & $15-24$ & 25-34 & $35-44$ & 45-54 & $55-64$ & $65-74$ & 75+ \\
\hline $\mathrm{HH}$ Income Base & 1,345 & 6,313 & 6,914 & 7,478 & 6,258 & 4,297 & 4,983 \\
\hline$<\$ 15,000$ & 340 & 857 & 725 & 762 & 644 & 438 & 807 \\
\hline$\$ 15,000-\$ 24,999$ & 201 & 850 & 704 & 668 & 548 & 435 & 971 \\
\hline$\$ 25,000-\$ 34,999$ & 186 & 812 & 797 & 698 & 559 & 622 & 762 \\
\hline$\$ 35,000-\$ 49,999$ & 288 & 1,261 & 1,148 & 1,051 & 1,012 & 778 & 790 \\
\hline$\$ 50,000-\$ 74,999$ & 214 & 1,376 & 1,540 & 1,735 & 1,317 & 1,151 & 848 \\
\hline$\$ 75,000-\$ 99,999$ & 55 & 576 & 783 & 892 & 703 & 351 & 436 \\
\hline$\$ 100,000-\$ 149,999$ & 49 & 455 & 837 & 1,087 & 962 & 306 & 289 \\
\hline$\$ 150,000-\$ 199,999$ & 9 & 83 & 259 & 370 & 332 & 126 & 47 \\
\hline$\$ 200,000+$ & 3 & 43 & 121 & 215 & 181 & 90 & 33 \\
\hline Median HH Income & $\$ 31,415$ & $\$ 41,172$ & $\$ 50,850$ & $\$ 55,786$ & $\$ 54,974$ & $\$ 46,832$ & $\$ 34,158$ \\
\hline Average $\mathrm{HH}$ Income & $\$ 38,067$ & $\$ 51,015$ & $\$ 63,987$ & $\$ 71,553$ & $\$ 72,051$ & $\$ 58,948$ & $\$ 45,573$ \\
\hline \multicolumn{8}{|c|}{ Percent Distribution } \\
\hline & $15-24$ & $25-34$ & $35-44$ & 45-54 & $55-64$ & $65-74$ & $75+$ \\
\hline $\mathrm{HH}$ Income Base & $100 \%$ & $100 \%$ & $100 \%$ & $100 \%$ & $100 \%$ & $100 \%$ & $100 \%$ \\
\hline$<\$ 15,000$ & $25.3 \%$ & $13.6 \%$ & $10.5 \%$ & $10.2 \%$ & $10.3 \%$ & $10.2 \%$ & $16.2 \%$ \\
\hline$\$ 15,000-\$ 24,999$ & $14.9 \%$ & $13.5 \%$ & $10.2 \%$ & $8.9 \%$ & $8.8 \%$ & $10.1 \%$ & $19.5 \%$ \\
\hline$\$ 25,000-\$ 34,999$ & $13.8 \%$ & $12.9 \%$ & $11.5 \%$ & $9.3 \%$ & $8.9 \%$ & $14.5 \%$ & $15.3 \%$ \\
\hline$\$ 35,000-\$ 49,999$ & $21.4 \%$ & $20.0 \%$ & $16.6 \%$ & $14.1 \%$ & $16.2 \%$ & $18.1 \%$ & $15.9 \%$ \\
\hline$\$ 50,000-\$ 74,999$ & $15.9 \%$ & $21.8 \%$ & $22.3 \%$ & $23.2 \%$ & $21.0 \%$ & $26.8 \%$ & $17.0 \%$ \\
\hline$\$ 75,000-\$ 99,999$ & $4.1 \%$ & $9.1 \%$ & $11.3 \%$ & $11.9 \%$ & $11.2 \%$ & $8.2 \%$ & $8.7 \%$ \\
\hline$\$ 100,000-\$ 149,999$ & $3.6 \%$ & $7.2 \%$ & $12.1 \%$ & $14.5 \%$ & $15.4 \%$ & $7.1 \%$ & $5.8 \%$ \\
\hline$\$ 150,000-\$ 199,999$ & $0.7 \%$ & $1.3 \%$ & $3.7 \%$ & $4.9 \%$ & $5.3 \%$ & $2.9 \%$ & $0.9 \%$ \\
\hline$\$ 200,000+$ & $0.2 \%$ & $0.7 \%$ & $1.8 \%$ & $2.9 \%$ & $2.9 \%$ & $2.1 \%$ & $0.7 \%$ \\
\hline
\end{tabular}




\section{Household Income Profile}

2 Cities and Towns (Places)_1

Santa Maria city, CA (0669196) et al.

Geographies: 2 Places

\begin{tabular}{|c|c|c|c|c|c|c|c|}
\hline \multicolumn{8}{|c|}{2017 Households by Income and Age of Householder } \\
\hline & 15-24 & 25-34 & 35-44 & 45-54 & $55-64$ & $65-74$ & 75+ \\
\hline $\mathrm{HH}$ Income Base & 1,208 & 6,328 & 6,751 & 6,897 & 6,508 & 5,097 & 5,172 \\
\hline$<\$ 15,000$ & 313 & 858 & 666 & 677 & 641 & 516 & 840 \\
\hline$\$ 15,000-\$ 24,999$ & 171 & 724 & 505 & 484 & 416 & 443 & 883 \\
\hline$\$ 25,000-\$ 34,999$ & 140 & 646 & 571 & 483 & 434 & 597 & 649 \\
\hline$\$ 35,000-\$ 49,999$ & 249 & 1,163 & 993 & 842 & 907 & 818 & 760 \\
\hline$\$ 50,000-\$ 74,999$ & 204 & 1,406 & 1,478 & 1,537 & 1,309 & 1,340 & 898 \\
\hline$\$ 75,000-\$ 99,999$ & 70 & 810 & 1,046 & 1,075 & 970 & 603 & 657 \\
\hline$\$ 100,000-\$ 149,999$ & 49 & 561 & 997 & 1,149 & 1,170 & 453 & 379 \\
\hline$\$ 150,000-\$ 199,999$ & 9 & 109 & 338 & 426 & 437 & 199 & 68 \\
\hline$\$ 200,000+$ & 3 & 51 & 157 & 224 & 224 & 128 & 38 \\
\hline Median HH Income & $\$ 33,202$ & $\$ 46,174$ & $\$ 58,296$ & $\$ 63,118$ & $\$ 64,006$ & $\$ 52,022$ & $\$ 38,279$ \\
\hline Average $\mathrm{HH}$ Income & $\$ 39,951$ & $\$ 56,358$ & $\$ 74,019$ & $\$ 80,536$ & $\$ 82,327$ & $\$ 66,691$ & $\$ 50,800$ \\
\hline \multicolumn{8}{|c|}{ Percent Distribution } \\
\hline & $15-24$ & $25-34$ & $35-44$ & 45-54 & $55-64$ & $65-74$ & $75+$ \\
\hline HH Income Base & $100 \%$ & $100 \%$ & $100 \%$ & $100 \%$ & $100 \%$ & $100 \%$ & $100 \%$ \\
\hline$<\$ 15,000$ & $25.9 \%$ & $13.6 \%$ & $9.9 \%$ & $9.8 \%$ & $9.8 \%$ & $10.1 \%$ & $16.2 \%$ \\
\hline$\$ 15,000-\$ 24,999$ & $14.2 \%$ & $11.4 \%$ & $7.5 \%$ & $7.0 \%$ & $6.4 \%$ & $8.7 \%$ & $17.1 \%$ \\
\hline$\$ 25,000-\$ 34,999$ & $11.6 \%$ & $10.2 \%$ & $8.5 \%$ & $7.0 \%$ & $6.7 \%$ & $11.7 \%$ & $12.5 \%$ \\
\hline$\$ 35,000-\$ 49,999$ & $20.6 \%$ & $18.4 \%$ & $14.7 \%$ & $12.2 \%$ & $13.9 \%$ & $16.0 \%$ & $14.7 \%$ \\
\hline$\$ 50,000-\$ 74,999$ & $16.9 \%$ & $22.2 \%$ & $21.9 \%$ & $22.3 \%$ & $20.1 \%$ & $26.3 \%$ & $17.4 \%$ \\
\hline$\$ 75,000-\$ 99,999$ & $5.8 \%$ & $12.8 \%$ & $15.5 \%$ & $15.6 \%$ & $14.9 \%$ & $11.8 \%$ & $12.7 \%$ \\
\hline$\$ 100,000-\$ 149,999$ & $4.1 \%$ & $8.9 \%$ & $14.8 \%$ & $16.7 \%$ & $18.0 \%$ & $8.9 \%$ & $7.3 \%$ \\
\hline$\$ 150,000-\$ 199,999$ & $0.7 \%$ & $1.7 \%$ & $5.0 \%$ & $6.2 \%$ & $6.7 \%$ & $3.9 \%$ & $1.3 \%$ \\
\hline$\$ 200,000+$ & $0.2 \%$ & $0.8 \%$ & $2.3 \%$ & $3.2 \%$ & $3.4 \%$ & $2.5 \%$ & $0.7 \%$ \\
\hline
\end{tabular}

